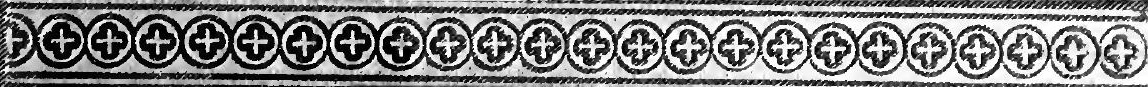

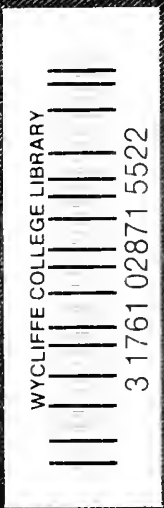




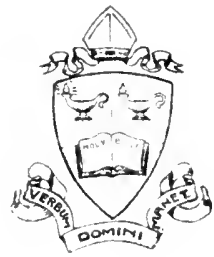

LIBRARY

\section{Illyglitte ế}

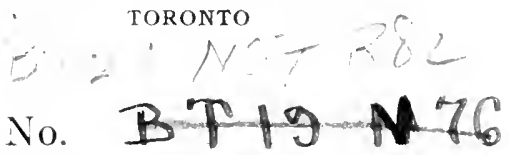

shelf No. B P P $A 76$

Register No. 8552 

ta

75 



$$
\text { , }
$$ 


\section{RUDIMENTS OF THEOLOGY. \\ A FIRST BOOK FOR STUDENTS. \\ BY}

JOHN PILKINGTON NORRIS, B. D.

OANON OF BRISTOL, AND EXAMINING CHAPLAIN TO THE BISHOP OF MANCEESTER.

$16 \mathrm{mo}, 285$ pages, $\$ 1.25$.

The Churchman (New York) in a review of this book, says : -

"This work was prepared as a handbook for theological students. But it is to reach a far wider field. It is capable of doing a most important service among all classes. We have seldom, if ever, met a inore satisfactory or a clearer presentation of the fundamental facts of theology than those given in these pages. The fact that the author wished to give only the rudiments of the Faith, and to produce a book which might serve as a kind of introduction to the science of systematic divinity, has, probably, induced him to bring his statements down to a level with the capacity of ordinary minds. But this is, in reality, the distinguishiug merit of his work. He begins witl stating the fundamental doctrines of the creed. God's existence, the Second Person of the Trinity, the Atonement, the Third Person of the Trinity, the Church, and the Sacraments, are the subjects taken up in the first part, and they are presented in a way which, it seems to us, leaves little room for improvement. The author has the rare faculty - it amounts really to genius - of saying just the thing that ought to be said, and of prescnting any truth in such a shape that the reader can easily take hold of it and make it his own.

"The second part is devoted to the soteriology of the Bible. Here the teachings of Scripture, both those of the Old and those of the New Testament, are brought together and explained, and shown to be the basis of the Church's creed.

"In going over a book like this, one cannot help contrasting the Anglican with the German method of imparting religious knowledge. Here every statement is a crystal, clear and exact. There is a condensation of thought into propositions that mean something.

"We commend this work to Chnrehmen generally as one from which all can derive profit. To the clergy it will serve as a model method of dogmatic teaching, and to the laity it will be a rich storehouse of information concerning the things to be believed."

\section{E. P. DUTTON \& CO., Publishers, New York.}




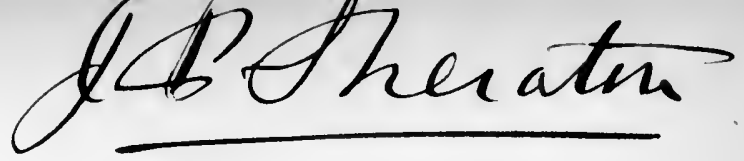

\section{RUDIMENTS OF THEOLOGY}

$\mathbf{A}$

FIRST BOOK FOR S'TUDENTS

BY

JOHN PILKINGTON NORRIS, B. D.

CANON OF BRISTOL, AND

EXaMiNiNg CHAPLAIN TO THE BISHOP OF MANCheSTER

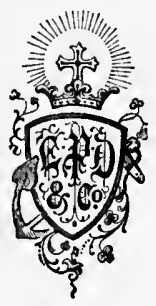

NEW YORK

E. P. DUTTON AND COMPANY

713 Broadway

1876 
RIVERSIDE, CAMBRIDGe:

STEROTIPED AND PRINTED BY

H. O. HOUGHTON AND COMPANY

$$
45178743 \mathrm{~V}
$$




\section{PREFACE.}

$I^{N}$ the following pages I have endeavored to meet a request often made to me by Candidates for Ordination, that I would put into their hands a compendious manual that might serve as a first book in Theology.

In the First Part the fundamental doctrines of the Creed are considered - the doctrine of God, of God the Son, of His Atonement, of God the Holy Ghost, of His sanctifying work by means of the Church and her Sacraments; and, relying mainly on the help I have myself derived from Hooker, Bull, Pearson, and (most of all) Waterland, I have tried to put the reader's thoughts into orderly shape on each of these subjects.

In the Second Part, by way of illustrating what may be called the method of theological induction, the doctrine of the Atonement is selected, and the student is invited to make a rapid survey of Holy Scripture, 
vi

PREFACE.

with a view to gathering therefrom what seems to be revealed to us respecting that mystery.

I shall be very thankful if some who read these pages find them helpful towards thinking out their own thoughts into clearness, and defining to themselves the common theological terms which they are daily using.

College Green, Bristol, Advent, 1875. 


\section{CONTENTS.}

\section{PART I.}

FUNDAMENTAL DOCTRINES.

CHAPTER $I$.

The Doctrine of God's Existence . . . . . . . . . . . 9

CHAPTER II.

Tile Doctrine of tile Second Person of tife Trinity . . . 30

CHAPTER III.

Tie Doctrine of the Atonement . . . . . . . . . . . 53

CHAPTER IV.

The Ductrine of the Third Perison of the Thintty . . 86

CHAPTER $V$.

The Doctrine of tile Cindrch . . . . . . . . . . . 109

CIIAPTER VI.

The Docrrine of The Sacraments . . . . . . . . . . 138

PART II.

THE SOTERIOLOGY OF THE BIBLE.

CIIÁPT'ER I.

The Teaching of tile Old Testament . . . . . . . . 172 
CHAPTER II.

The Teaching of the Four Gospels . . . . . . . . . 192

CHAPTER III.

The Teaching of Saint Paul . . . . . . . . . . . . 215

CHAPTER IV.

The Teaching of the Epistle to the Hebreivs, of Saint Peter, and Saint John . . . . . . . . . . . . . 235

CHAPTER V.

Soteriology of the Bible - concluded . . . . . . . . . 262 GLOSSARIAL INDEX . . . . . . . . . . . . . 279 


\section{PART I.}

FUNDAMEN'TAL DOCTRINES.

\section{CHAPTER I.}

THE DOCTRINE OF GOD'S EXISTENCE.

THE time is coming, if it have not already come, 1 when the truths of Christianity will no longer be taken for granted; when even the most elementary doctrines of religion - the doctrine of a personal Creator, for instance - will be considered an open question. It has been so before, and it will be so again, perhaps in our own generation, only with this difference - that whereas in the last century the doubters were for the most part scoffers, whose bad lives deprived them of any right to be heard in a matter so sacred, ${ }^{1}$ now in our century it is not so; earnest seekers after truth, whose lives are as strictly moral as our own, are putting the question to us in all seriousness, Is it possible for man to have any knowledge of God? It is the old question put to Job, three thousand years ago or more; by Zophar

1 See the Preface to Butler's Analogy. 
the Naamathite, "Canst thou by searching find out God?" And it is the question put to the Christian by the Positivist and by the Materialist in our own day; and it behooves us to have an answer, for not only our Christianity, but even our faith in God's zxistence is on its trial.

"Why," then, "do I believe in God?" Some possibly might answer, if they spoke the real truth, "Because all about me do. I have never considered the question for myself. I have adopted the opinion and belief of those among who I live." Clearly this is a weak and indolent belief, that will stand just so long as it is propped up on all sides by the belief of others. But if such a believer found himself among unbelievers, his faith would probably fail.

Why, then, do I believe in God? Another answers : "It is the first Article of our Creed, and our Creed is taken directly from the Bible, and the Bible must be true because it is God's word. The best men have believed this, and therefore I believe it."

This is a far worthier answer; it is the answer of one of docile mind, who mistrusts his own judgment, and wishes to lean on authority, and wisely chooses the best authority, the authority of the church in which he has been nurtured.

And yet clearly this answer will not suffice for those who have to do with the heathen on our frontiers, nor will it suffice in controversy with the scep- 
tic at home. And if the time is coming when all Christians will have to hold their own in general society, it is wholesome to consider well the foundations of our faith, and prepare ourselves prayerfully to give an answer to any who may ask us for a reason of the hope that is in us.

Now the question before us, "What grounds have we for believing in the existence of God?" goes to the very root of all religion. If it be impossible for man to have any knowledge of God, then all religion is an imaginary thing - beautiful it may be and refining as poetry is ; but of no further value, and of no obligation whatever. This is what the modern unbeliever says: "In the child, and in the childlike ages of the world, knowledge was very limited, and all the vacant spaces in the realm of thought were filled up by the imagination. Man's knowledge of natural causes was then so small that he was continually having recourse to what he called supernatural causes to explain the things about him, - such as magic, demonology, sorcery, and the like. It was in those early days that Religion won her empire over the minds of men. But now, in the maturity of the human intellect, science or knowledge of Nature is continually extending her frontiers, and thus the supernatural is being slowly but surely eliminated from the realm of thought; the natural pushing out the supernatural; science ever growing, and leaving 
less and less room for imagination; and thus religion coming to be put away with other childish things."

The modern materialist says further: "Science, that is, true knowledge, can only deal with facts, and what may be proved by careful induction from those facts. If there be a God, - and I do not deny that there may be, - but if there be, it is all one to me as if there were not, inasmuch as I have no means of knowing anything about Him. Science rests on facts, religion on imagination; therefore I prefer science. And science knows nothing, can know nothing, of Grod."

I do not think this is an unfair statement of the views of the modern unbeliever. What have we to say in answer?

It might perhaps be thought enongh to urge in reply the powerful argument of Butler, that by the sceptic's own showing there may be a God, though he knows Him not; and if this be so, what a tremendous risk he is incurring in thus acting as if there were no God! Would it not be infinitely safer to act on the supposition that there is a God? For if the supposition prove wrong, he would have lost nothing; if it prove true, le would have gained everything.

But this argument suited Butler's day better than our day; for in our day the sceptic might perhaps reply that he was living as conscientiously as Bishop Butler, and had nothing to fear from either issue. 
What, then, have we to reply to him? He says, "No knowledge is worthy of the name of knowledge, unless it be scientific." These terms need definition, but we can afford to grant the assertion, and we claim for our theology that it is scientific. Theology used to be called the Mother of Sciences; and though its study has been sadly and shamefully neglected of late years compared with that of other sciences, yet a science it is, and, please God, will one day be recognized once more as the noblest of sciences.

"Nay, but" (he says) "science in the scholastic sense of the term - a mere spinning out of ideas by the help of the syllogism - is an exploded thing. Inductive Science is what we now mean by sciencescience resting on well-ascertilined facts."

This, too, we grant, and we claim for our theology that it rests on a basis of well-ascertained facts. "But your so-called facts," he still uiges, "are supernatural. And the presumption against any fact that claims to be supernatural is overwhelming, outweighing any amount of evidence in its favor, - for this simple reason, that man has no faculties wherewith to apprehend the supernatural. If there be a God, He is utterly out of reach of man's faculties."

This again we partly grant. We grant that man has no. faculties wherewith to reach God. But though man cannot reach God, yet God, as the sceptic must allow, if there be a God, can reach man. 
And further, if there be a God, it is very highly probable that He should in some way reveal Himself to man.

That God should create such a being as man, and yet leave him in absolute ignorance of Himself, is a thing in the highest degree improbable. The presumption is, on such a hypothesis, greatly in favor of a Revelation. And a revelation - that is, a communication between God and man - whenever it occur, must, from the necessity of the case, involve supernatural facts. And that such supernatural facts should make a profound impression on the generation of men that witness them, and should be carefully recorded, is precisely what we should expect. It only remains for future generations to verify these facts as in any other science.

For these simple reasons surely the unbeliever has no right whatever to say there is an overwhelming presumption against the facts of our religion being true. On the hypothesis of God's existence, the presumption is in favor of some such facts having really occurred in the world's history.

And there is a further probability. If this world be a kind of school (as it is allowed by all to be) in which man is being educated to rise as much as possible above his lower animal nature, and trust more and more for his happiness to the exercise and effort of his higher, nobler nature; and if man is noblest 
when he is least governed by motives of sense and most governed by motives of faith, faith in the unseen - forming a long hope, and working steadily towards this hope - then it is probable that these revelations will be few and far between; and probable, moreover, that as the intervals protract themselves, many, yielding to the lower nature, will fall away and lose heart, until, in God's good time, there burst upon the world another revelation. Such a time, such a long interval, are we passing through; it seems long since the fathers of our religion fell asleep, and all things continue as they were, and the tension of faith is becoming too great for many, and even the faithful are fain to cry, " $O$ that Thou wouldest rend the heavens and come down!"

But the word standeth sure, " He that endureth to the end shall be saved." "In your patience possess ye your souls." One of these days the whole world will be startled into faith; as in the days of Noah, as in the days of the Apostles, as in lesser degree in the sixteenth century, when the revived study of St. Paul's Epistles stirred Christendom into new life, so it will be again; thère will be another revival, another age of martyrdoms, it may be ; another universal cry, "Men and brethren, what must we do to be saved?" And then the end will come; and every eye shall see Him!

But in the mean time, in this quiet time, in this 
trying time of waiting, let us hold fast our confidence, let us see well to the foundations of our faith, that we may be able to give a reason for the hope that is in us.

It behooves us all, for our own sake, as well as for the sake of others whom we may be able to influence, to understand clearly that the fundamental doctrines of our religion are in the true sense of the term scientific, that they rest on facts, and are such as a reasonable man may apprehend, and with all his mind and strength embrace and believe.

We will commence with the first article of our Creed, the doctrine of a personal Creator.

\section{"I BELIEVE IN ONE GOD."}

Is it possible for man, unaided by Revelation, to attain to a true belief in God? St. Paul answers this question, in three passages, affirmatively.

At Lystra he found himself addressing a crowd of uneducated heathens:

He told them that even among them God had not left Himself without witness.

At Athens he was confronted by a group of heathen philosophers ; he appealed to their own heathen literature as confessing that man is responsible for knowing God, for man is God's offspring.

In the first chapter of his Epistle to the Romans he declares yet more distinctly that the heathen are 
accountable for a knowledge of God, and guilty if they fail to know Him and worship Him.

Evidently, then, we have the authority of Holy Scripture for inquiring what evidence philosophy or science furnishes of God's existence. It is an inquiry which in all ages has engaged the attention of wise and good men; and though we who have the clear light of revelation are (so to speak) independent of the result, yet time is well spent in the investigation of other evidence.

There are three distinct lines of argument by which men have sought to prove the existence of one supreme God.

First, there is the argument from first principles, $i$. e., from the reason of the thing, commonly called the à priori argument.

Secondly, there is the argument of natural theology, an induction from what we observe in nature, called the à posteriori argument; and

Thirdly, there is the argument which is drawn from conscience and man's universal sense of responsibility, called for shortness' sake the moral argument.

Perhaps the most popular way of putting it would be to say, God's existence has been proved (1) from reasoning; (2) from nature; (3) from conscience.

It may be interesting to describe, as briefly and clearly as may be, these three kinds of proof. 
And first, the proof drawn from reasoning, what is called the $a$ priori argument.

It was never better stated than by Anselm in the twelfth century, and yet it may be doubted whether any of his readers have ever felt that his brilliant argument would be convincing if it stood alone.

He reasoned thus: "I have in my mind the idea of the most perfect being conceivable. The most perfect being conceivable must have the attribute of necessary existence. One whose existence was contingent would not be the most perfect conceivable. Necessary existence implies actual existence. An absolutely perfect Being therefore actually exists, and He is God."

And thus with characteristic fervor he concludes: "He, therefore, who understands this, understands that God cannot be conceived of as non-existent. Thanks be to Thee, O Lord, thanks be to Thee, that what I at first believed through Thine own endowment, I now understand through Thine illumination, so that even if I were unwilling to believe that Thou art, I cannot remain ignorant of Thy existence."

This mode of reasoning was suited to the habits of thought in the Middle Ages. But it could never be made intelligible to simple folk, and is of doubtful value at all times.

It was not the witness appealed to by St. Paul at Lystra, at Athens, at Rome. It is deeply interesting 
and reassuring that he, the inspired Apostle, appealed to that other argument, which modern science is continually strengthening - the argument drawn from the order, harmony, and evident design pervading the whole universe of Nature. "Because that which may be known of God is manifest to them ; for God hath showed it unto them. For the invisible things of Him from the creation of the world are clearly seen, being understood by the things that are made, even His eternal power and Godhead; so that they are without excuse." (Rom. i. 20.)

How modern science has been working out this thesis !

Think for one moment of the proof of design - the proof (that is) of a personal Creator - that may be found in the correspondencies of Nature. The correspondency, for instance, between plants and animals - plants by their curious chemistry preparing precisely that kind of food which the digestive organs of the animal can assimilate.

So that the holy Psalmist (I quote an old writer ${ }^{1}$ ), considering this preparation of food for the beasts of the field, and taking upon him to be as it were their chaplain, had reason to say this grace for them: " The eyes of all wait upon Thee, and Thou givest. them their meat in due season; Thou openest Thine hand, and fillest all things .ring with plenteousness."

1 Barrow. 
Or consider, again, the correspondency between our organs of sense and all that meets them in the outside world: the retina of my eye made sensitive to that ray of light which is made to vibrate from the sun; my ear so curiously fitted to receive the pulsations of sound; my organs of smell so manifestly adjusted by one and the same Creator to the pleasant fragrancy of the fine pollen that floats into the air from a thousand herbs and flowers. Whence such admirable congruity between me and the world around me, unless a designing mind made both?

But there is one correspondency between man and nature so preëminently striking that it is marvellous it has not found more frequent mention in Natural Theology.

The Bible tells us that God made man in his own image ; science gives us a proof of it, showing that in very truth the ideas of man's mind are akin to the ideas of the Divine mind.

The proof is capable of very simple statement. ${ }^{1}$

We all know that the science of geometry was worked out in ancient times from a few very simple principles which man found in his own mind. It was worked out by Euclid and Archimedes by pure reasoning, out of their own minds. Ages afterwards the telescope was discovered, and the courses of the planets and comets were ascertained; and the Gali-

1 I owe what follows to Whewell's Philosophy of Discovery. 
loes and Newtons beheld with reverent wonder that these heavenly bodies, in all their mazy revolutions, do obey those very laws of geometry, which the mathematician, hundreds of years before, had evolved out of the necessary conditions of thought involved in the constitution of his own mind.

How was this correspondency to be accounted for? those curves traced on the sand of his study floor by an Archimedes found to be the very curves sivept out in the heavenly spaces by the mighty comets? I say how and why was this? How was it that man found his thoughts thus verified in God's universe?

One only explanation is there: that God had the same thoughts, and cliose to exemplify them in that universe, the ideas of the Divine mind and the ideas of the human mind thus wonderfully corresponding! Man made in the image of his God. There is no other explanation.

But we must hasten on to the third line of argument for God's existence, the moral proof. What do we mean by conscience? Is it enough to say that it is a moral sense within us? Certainly not. A moral sense might distinguish between right and wrong, but it would not impel us to the right, and deter us from the wrong, as conscience doẹs. There is in conscience a sense of responsibility, of accountableness, and that, too, when we are most alone. But mark what this inevitably carries with it: responsi- 
bility, accountableness, to whom? To some one clearly, else the word responsibility has no meaning.

Surely they are not wroug who explain conscience in the words of Tertullian, a mind naturally conscious of God. That, depend upon it, is the real meaning of that mysterious sense within us which we call our conscience, implanted within us by Him in whose image we are made. If this proof that we are created by a personal Creator be strong, as I think it is, when resting simply on the consciousness of each, how much stronger does it become when we observe the universality of this conscience! More or less it is found in all men, and not only so, but it is found to lead all men to the same conclusions in the main about right and wrong. How is this? There can be but one answer, that this conscience is a reflex, however faint, of the Divine mind of Him in whose image we are formed.

But these three proofs on which we have been dwelling - the proof from the reason of the thing, the proof from nature, the proof from conscience are all of the nature of an argument; and what is argumentative cannot be within reach of all. If such arguments were the only ways of attaining to the knowledge of God, then simple minds could not know Him, which God forbid, for the simplest often know God most truly. There must be yet another 
kind of knowledge of God of easier apprehension. What is it? Is it the knowledge of God that we derive from the Bible? True, we have not yet spoken of that; we purposely postpone that till we come to meditate on Him, the only-begotten Son, who hath declared to us the Father.

But I mean not that kind of knowledge now. Nor is it God's written Word that we most of all depend on for our faith in God. For if it were so, then the. best-read Bible student would know God best. And it is not so. Many a poor unlettered woman who has spent months or years in a darkened sick chamber, unable to read a single page of her Bible, may have a knowledge of God firmer, deeper, truer, than the greatest of theologians. There must then be some more excellent way of knowing God that we have not yet mentioned. What is it?

There are two kinds of knowledge of a person. When we speak of having knowledge of a person, we may either mean that we know all about him, or we may mean that we know the person himself. Mark the difference. You may know very little indeed about even your own father; perhaps you know nothing of his birth, or parentage, or early education, or other surroundings, but you know him, you know the look of his eye, the sound of his voice; you know him because you love him.

Now may we not have this latter kind of knowl- 
edge of God, although haply we know little about God? Ask that poor woman in her sick room how she comes to know God, and she will tell you, "Every day for the last ten years, for the last twenty years, I have spoken to Him ; aye, and $\mathrm{He}$ has answered me. I have taken my sorrows to Him, and I have found relief. I have confessed my faults to Him, and He has given me a sense of pardon; when no one else befriended me, $\mathrm{He}$ has been my friend; when no one else has cared to comfort me, He has been my conforter."

Can any knowledge of God equal this? Surely it must have been this kind of knowledge of God that Christ meant when He said, that to know God truly was eternal life. Do we wish to attain to it? How shall we? Go ask that poor woman, and she will tell you. How did you find God? "I never found God" (she will answer), "it was God who found me. Time was when I trusted to other supports, and one by one they all failed me, and I was sinking lower and lower; and in my misery $I$ thought $I$ would try and pray as my mother taught me when I was a child; and pray I did with all my strength, simply and merely because I was utterly miserable. And from that very day I found a support - a support I had never felt before - a support on which I could bear my whole weight. I had sunk through all other supports, but this, oh, it was so strong be- 
neath me! strong as the everlasting arms beneath me! And not beneath me merely, but within me - a new power I felt within me. It is none of my own, for it has made me quite another woman; so it must come from outside me. I think, I feel sure, it is God working mightily for me. I feel as if I now know Him from long experience. I can say, as no books could ever have taught me to say it, 'I believe in God the Father.' He hath not left Himself without witness. His witness is within me."

What shall we call this sort of evidence of God's existence? It is not drawn in the way of argument from reasoning, nor yet from nature, nor yet from conscience. We can only call it a personal knowledge of God, knowledge of a like kind to that which, between man and man, intercourse leads to. Between man and God we are unwilling to use the familiar term "intercourse;" communion is the more reverent word, but it means the same thing. The conviction of God's existence that rests on such communion is probably the strongest possible.

But how did the communion first begin? In this case that we are supposing it was not suggested by the reading of God's Word. The woman thought of praying because in her childhood she had been taught to pray, because she knew her mother had prayed, because the best people of her acquaintance prayed. 
In a word, because she had been brought up in a society (the Christian Church) which taught the duty of prayer. Hence the first suggestion, she learned her religion (as all of us do; may we not say as we are intended to do?) at second hand. But now she has made it her own. ${ }^{1}$ She knows God from her own experience of His dealings with her ; she has a deepseated consciousness of His existence, which makes her as certain of it as of her own being.

But, some may say, All this is very well, but nothing to us. What we were seeking was some scientific proof of God's existence - a proof that would be satisfactory to one accustomed to reason inductively on the facts around him.

Our answer is, that in the proof we are now offering you may find, if you will, a proof of the kind you desire.

Is not that poor woman's altered life a plain fact? Can you deny that she is living, as she now lives, under the influence of some very strong motive? Does this fact stand alone? Are you not surrounded by facts of the same kind ? ${ }^{2}$ In every village of the land

1 "Evangelio non crederem nisi me Ecclesiæ Catholicæ commoveret auctoritas." - Aug. (Ep. Manichai, viii. 270). I was led to the Bible by the Church. Cf. John iv. 42.

2 " Ecquid verisimile est, ut tot ac tantæ (ecclesia) in unam fidem erraverint ?" - Tertull. de Proscriptione, 28. "Perperam evangelizabatur, perperam credebatur; tot milia milium perperam tincta, tot opera fidei 
are there not living persons whose whole character has been similarly changed by the self-same motive force - persons totally unknown one to another? And is it not so all over Christendom? Can these facts be denied? Are they not worthy of being studied, of being scientifically studied? Are you not bound as a philosopher to recognize these facts and investigate them, applying to them your inductive method, seeking for some general law that will adequately account for them? Are phenomena of the moral world less capable of the inductive method than facts of the physical world? Take a corresponding case in the physical world. Men in days of yore noticed how the waters of the sea, twice in twenty-four hours, came rising and swelling in this creek and in that creek, all along their coasts, and on inquiry they found it was so on other coasts, and in other seas, all round the globe. Was it a mere whim of the inconstant waves, not worthy of a philosopher's attention? Was it not rather a mystery that challenged inquiry and investigation? And when every possible explanation, drawn from the winds or from the configuration of the shore, had been exhausted

perperam administrata, tot virtutes, tot charismata perperam operata, tot sacerdotia, tot ministeria perperam functa, tot denique martyria perperam coronata!" Ibid. c. 29. "Jam credere cœperam nullo modo Te fuisse tributurum tam excellentem illi Scripturæ per omnes jam terras auctoritatem, nisi et per ipsam Tibi credi et per ipsam Te quæri voluisses." Aug. Conf. vi. 5. 
and had failed to account for it, was the inquiry abandoned? Was it not rather stimulated, men's minds never resting till a Newton or a Laplace had found the unseen mysterious power which the waters of the ocean were obeying; found it, not in this earth, but where men had least suspected, in those distant heavenly orbs which night and day are looking down upon the face of the great deep, and exercising thereupon their strange attractive influence.

And are these phenomena of the moral world, men's wills and unruly passions, in all climes and in all ages, yielding themselves to obey a mighty unseen Power which controls them, less worthy matter for philosophic thought? Human hearts rising and heaving under one and the same mighty impulse all round the world, is not this a patent fact urgently demanding explanation?

And if, after exhausting every other hypothesis, philosophers find the only possible solution, not on earth but in heaven - in the conception of a Supreme Personal Being, the Father of the spirits of all flesh - why should they refuse assent? - nay, why should not they, too, enter the sanctuary, and learn to know Him with that deeper personal knowledge which that poor suffering woman in her sick chamber had attained to, and made her own forever?

And now to sum up this chapter. We have 
glanced at some of the proofs commonly given of God's existence - the proof from the reason of the thing (as men say), the proof of natural theology, and the moral proof resting on the conscience of mankind.

We have tried to show that there was vonchsafed to some, and those the holiest, a far more convincing proof, derived from a direct personal knowledge of God.

And, finally, we rentured to suggest that this last, though attainable only by those who are within the sanctuary, was nevertheless to the philosopher outside well worthy of consideration. For was it not a plain, undeniable fact - as patent as any phenomenon of the natural world - that numbers of men, and those the noblest, of every age and nation, were actuated by an unseen, mysterious Power, controlling them and constraining them to make efforts directly opposed to all the impulses of their common nature?

Thus we claim for our belief in God a truly scientific basis. 


\section{CHAPTER II.}

THE DOCTRINE OF THE SECOND PERSON OF THE TRINITY.

WE saw in the first chapter that before any of us can attain to that deeper consciousness of God which grows out of communion with Him, the belief in God must have been in some way suggested to us. And we saw further, that the great majority of us owed the suggestion to our nurture within the pale of the Church.

The individual Christian may not require to know the grounds on which the Church's teaching ultimately rests; but clearly the Church is responsible for producing her reasons if required to do so ; they are the title-deeds of her inheritance.

This leads us at once to Revelation, and so to the second Article of our Creed, on which we must now enter; and, indeed, it is most true, we cannot understand the Church's faith in the first Article of her Creed unless we go farther, and seek to understand her faith in the second.

We could never have really believed in God the Father Almighty, Maker of heaven and earth, unless 
we had learned to believe also in Jesus Christ, His only Son our Lord. We cannot claim the blessing of that knowledge of God which is life eternal, unless we complete the verse, "This is life etermal, to know Thee the only true God, and Jesus Christ whom Thou hast sent."

For what saith St. John's Gospel in another place? "No man hath seen God at any time: the only begotten Son, which is in the bosom of the Father, He hath declared Him." (i. 18.) And what was the answer to Philip when he said, "Lord, show us the Father, and it sufficetl us"? "Jesus saitlı unto him, Have I been so long time with you, and yet hast thou not known Me, Philip? He that hath seen Me hath seen the Father; and how sayest thou then, Show us the Father?" (xiv. 9.)

This, then, is our Church's answer to any one who asks us whence we derive our knowledge of God. We derive it from a revelation made by Oue who, eighteen hundred years ago, declared Himself to be the Son of God.

This is our answer. But this answer lays us open to the further question, "On what grounds do you believe that Jesus Christ was the Son of God?" To this question we must be prepared to make answer. But here let me ouce more guard myself. When I say we must be prepared to answer this question, I do not mean that each Christian must be prepared to 
answer it. Is every soldier responsible for knowing the grounds on which war has been declared before he draws his sword? Is every citizen responsible for understanding the policy of his country before he pays a tax to carry out that policy? It is enough for each to answer, "I accept in this matter the judgment of those in whom I have confidence." So with the individual members of a church, when asked for the grounds of their faith, it may be enough for them to say, "I have confidence in the Church to which I belong. To my Church I refer you."

But if this be so, then all the more incumbent is it on the Church to see to it that the grounds of her faith be clear and distinct, and be made intelligible from age to age, and accessible to all who may wish to know them.

What, then, are our Church's grounds for teaching her members to believe in Jesus Christ, God's only Son our Lord?

Now, it may seem at first sight as if this question of Christ's Divinity opened up questions of evidence, of the authenticity of the New Testament, of its inspiration, of the credibility of miracles, and many other questions equally difficult. Into none of these do we propose to enter. They would utterly exceed the limits of this volume. There is one kind of evidence which is perpetually fresh, needing no knowledge of history, no critical apparatus, no philosophy. 
It is Christ's self-revelation, contained in those four Gospels, which you have in your hands. Never mind now how those Gospels came into your hands ; never mind now what claim they may have to inspiration. Read them, that will suffice. Read them as you might if an utterly unknown stranger had placed the volume in your hands, and left it there without saying a word about it. You will find the portraiture of One called Jesus Christ. Study that portraiture, and say honestly whether it could possibly have been invented; and then, further, say honestly whether it is possible that such an one conld deceive or be deceived in any claim that $\mathrm{He}$ put forward, and, lastly, read His words carefully and answer this plain question, "Whom did He claim to be?"

First, then, could the character of Christ possibly have been invented? Writers of fiction who wish to portray excellence have to compile. Our Lord's character could not have been so compiled, for it was new and original. Long accustomed as we have been to meditate upon the graces of Christ's character, perhaps we hardly realize how unique they were when they first appeared in Christ. That perfect courage, combined with perfect meekness; that burnished, crystalline purity on which slander feared to breathe; that spirituality - a word which had no existence before Christ's Advent: these were qualities mankind had never seen before, and could not have imagined. 
Then, secondly, is it really possible to suppose that Christ was either self-deceived or deceiving others? That He was deceiving those around Him, none in our day dares to suggest for very shame. But it has been whispered that $\mathrm{He}$ was an enthusiast, of visionary mind, dreaming beautiful dreams, and persuading Himself they were or might be made realities. One who so constantly, and even sternly, repressed and discountenanced such habits of mind in others can hardly have had them Himself. Those whom $\mathrm{He}$ praised were not those who cried "Lord, Lord," or those who blessed the womb that bare Him, or those who protested they would die with Him,-reeds shaken by the wind. Anything like exaltation in His disciples Christ promptly checked. ${ }^{1}$ He disclaimed all mystery in His teaching. ${ }^{2}$ If there is one thing more striking than another it is His preference of plain practical virtues to any amount of enthusiasm without them. We may safely assert (for all who have studied His character will allow it) that whatever Christ claimed to be, that $\mathrm{He}$ believed Himself to be, and that He was.

Whom, then, thirdly, did He claim to be?

But before we enter on this inquiry let us revert for a moment to the consideration of Christ's character, and mark well that there is one feature wanting in that character - a feature which we are ac-

Mark vi. 31 ; Luke x. 20, xxii. 38 ; John xiii. 38.2 John xviii. 20. 
customed to regard as essential to complete our conception of a really saintly man. In Christ the grace of penitence appears not. Never once do we read of our Lord's penitence. No confession of sin, no acknowledgment of a fault, ever passed His lips. On the contrary, He challenges those around Him to convince Him of $\sin$ if they can. "Which of you convinceth $\mathrm{Me}$ of $\sin$ ?" Even in His own selfcommuning we overhear Him saying, "The Prince of this world cometh, and hath nothing in Me." $\mathrm{He}$ is not conscious of a single failing.

Surely there is a mystery here separating Him at once from all other men, even the holiest. For " if we say that we have no sin, we deceive ourselves, and the truth is not in us."

Not so Christ. Clearly there is something here urgently demanding explanation. It may be that in proceeding to examine the claims which Christ put forth in His teaching - both in the manner and in the matter of it - we shall find the explanation.

And, first, the manner of His teaching. Observe the unbounded claim of superiority over all around Him. He ever speaks of Himself as their Lord and Master, as born to be a King, as one who can forgive sins, as appointed to be the Judge of all mankind. And yet we feel at the same time that in Him, somehow, this is not self-assertion. His attitude is always that of one who takes these claims for granted; of 
one who need not assert them; of one who was of necessity and transcendently above all around Him.

Viewing Him as a man only, for the moment, this would be utterly inexplicable. For $\mathrm{He}$ is, all the while, the lowliest of the lowly; when $\mathrm{He}$ was reviled, reviling not again; when He suffered, threatening not; content to endure all and bear all in the meekest silence!

Now let us turn to the matter of His teaching. Here at once we are confronted by a most striking peculiarity in it. One half of it - almost the whole of it as recorded by St. John - was concerning Himself, concerning His own Person. His one purpose, through whole chapters of St. John's Gospel, seems to be to set forth Himself !

Those about Him say, "What shall we do to be saved?" Christ answers, "Believe on Me." They ask, "Whither shall we go?" Christ answers, "Come to $\mathrm{Me}$, and ye shall have eternal life. I am the way, the truth, and the life. He that believeth in $\mathrm{Me}$ shall be saved; He that will not believe in $\mathrm{Me}$ is condemned; he that rejecteth $\mathrm{Me}$ will God reject."

"Ye believe in God, believe also in Me!" Conceive, for one moment, any other man, the greatest, the holiest you have ever heard or read of, using such words as these; or, again, "This is life eternal, to know God and to know Me!" Assuredly there is a mystery about the Person of Him who thus speaks! 
And yet $\mathrm{He}$ denies all the while that $\mathrm{He}$ is bearing witness of Himself. $\mathrm{He}$ is only delivering a message about Himself which $\mathrm{He}$ has been commissioned to deliver. Commissioned by whom? By One of whom He was ever speaking as His Father in an absolutely unique sense - in a sense in which no other man could call God His Father.

Can we wonder that the Jews in their unbelief were utterly shocked, and called this blasphemy? And did Christ disclaim or explain away the sense in which His words were understood? Not for one moment. He would vouchsafe no word of qualification in self-defence. The mystery was to remain.

"A greater than Jonah is here!"

"A greater than Solomon is here!"

"Ye are from beneath, I am from above!"

"Before Abraham was, I am."

He pushes the mystery into an absolute paradox, and they take up stones to cast at Him.

But to His inner friends, observe how $\mathrm{He}$ more and more unfolds it, and gradually carries on His self-revelation. Observe this especially in that last discourse before $\mathrm{He}$ suffered; from point to point how He leads them to understand His Person.

He is returning to His Father. Would they follow? "I am the way: no man cometh to the Father but by Me." $\mathrm{He}$, and $\mathrm{He}$ only, can give them that knowledge of God which is eternal life; and how? 
"If ye had known $\mathrm{Me}$, ye should have known my Father also." See how He stimulates them to know more of Him, and to ask Him questions. And first Philip and then Thomas question Him. And still more is revealed. Beholding Him, they behold the Father; for the Father, in some mysterious way, dwelleth in Him. "Believe me that $I$ am in the Father, and the Father in Me."

Thus $\mathrm{He}$ leads them on, until at last, speaking as they acknowledge, plainly, no longer in parable, but most clearly: "I came out from God;" "I came forth from the Father, and am come into the world;" again, "I am leaving the world, and going to the Father." His disciples said unto Him, "Lo, now speakest Thou plainly, and speakest no proverb. By this we believe that Thou camest forth from God."

One more clinching testimony $\mathrm{He}$ will bear for His Church's sake. He is on His trial; trial for putting forth claims that seemed plainly blasphemous, for claiming to be God's Son in a way that implied equality with God. Out of His own mouth they would fain have evidence of this.

The High-priest, therefore, puts Him upon oath; adjures Him by the living God to tell the Court whether $\mathrm{He}$ be or no, in this sense, the Son of God. Death is the penalty if He answers "yes." And He accepts the oath, and declares Himself the Son of 
God in this highest and most awful sense, and dies a martyr to this truth.

And yet once again. In His disciples' minds, if there had lingered any doubt, His resurrection had removed it. Thomas's exclamation of wondering adoration, "My Lord and my God!" did but give expression to the faith and conviction of all now. And $\mathrm{He}$ has gathered them together for His final charge ere $\mathrm{He}$ ascend before their eyes to heaven.

"All power is given unto $\mathrm{Me}$ in heaven and in earth. Go ye, therefore, and make disciples of all nations, baptizing them in the Name-" what Name? In the Name revealed to Moses, Jehovah? In the Name by which Clirist had taught them in the earlier days of His ministry to know God, the Name of the Father? No. He has taught them more now; He has taught them a deeper, fuller knowledge of God now in Three Persons; and of these Three everblessed Persons, $\mathrm{He}$ is Himself the midmost : - "In the Name of the Father, and of the Son, and of the Holy Ghost."

The self-revelation is complete.

And on this self-revelation is grounded the Church's surest argument for the Divinity of Her Lord.

This doctrine is stated very shortly in the Apostles' Creed; we there acknowledge Christ's Divinity: "I believe in Jesus Christ, God's only Son our Lord." 
But if this had been the only creed bequeathed by those early ages to the Church, we should all feel that we were asked to believe something so astounding, so perplexing, so inexplicable, that, one may almost fear, the doctrine of Christ's Divinity would have seemed to later ages so laden with difficulty as to be incapable of apprehension.

For one moment let us try to divest ourselves of all knowledge of it derived from other sources, and conceive ourselves asked to believe these statements of the Apostle's Creed in all their abruptness, without any explanation whatever: "God the Father," and "His only Son," equally " our Lord." How can this be?

And again, "Born of the Virgin Mary," that is, of a woman, and yet the Son of God. How can this be?

The Apostles' Creed puts these statements before us without one single word of further definition.

It is the fashion to speak of the Apostles' Creed as a very simple creed, and of the Nicene and Athanasian Creeds as difficult. It has been observed ${ }^{1}$ that in one sense the reverse is far more true. It is the Apostles' Creed that is the really difficult creed, and it is those other creeds which enable us to understand it.

If the Apostles' Creed stood alone, and the Christian

1 Sadler's Church Doctrine Bible Truth. 
had no other clue to what the Church and the Bible intended him to believe, he would be in danger of falling into all sorts of erroneous ideas about our Lord's Person.

$\mathrm{Nay}$, it need not be put as an imaginary case. It was really so. In the second and third centuries the Apostles' Creed was the Church's only creed. Converts seeking baptism were required to adore Jesus as the only Son of Grod, and to believe that He was both God and Man, without any further explanation, except such as oral teaching might supply, or such as they might, or might not, be able to collect for themselves from Holy Scripture.

And what was the result? The result was that thouglitful minds, trying to see distinctly the truth of Christ's Divinity and the truth of His Manhood, were torn with perplexity, and drifted away into all kinds of grievous errors.

Then the Church began to perceive that she was asking too much in requiring her catechumens to believe the naked truth, that Clirist was a Divine Being of twofold nature, without placing in their hands any symbol of fuller definition.

And those mighty intellects of the fourth century, raised up surely by God's providence for this express purpose, gifted with a power of thinking out the very deepest questions into clearness and distinctness, - foremost among them St. Athanasius, the two 
Gregories of Cappadocia, and St. Basil, - these and others of the Western Church - Hilary of Arles for instance, ${ }^{1}$ - defined this doctrine for the Church. With exhanstive care they collected and collated all the Scriptures that bear upon the question, and by a true inductive intuition they were enabled to induce upon these various statements the one master idea which harmonized them; bequeathing to all time the result of their labor and of their conflict (for there were many gainsayers) in the shape of those two other creeds of the early Church. And a work was thus done of which it is hardly too much to say that it neither could be, nor ever need be, repeated.

For us in these later ages it only remains gratefully and reverently to study and hold fast these grand definitions of our holy Catholic Faith.

Let us now endeavor, briefly but as clearly as may be, to unfold to ourselves the terms in which these two later Creeds explain and define the great doctrines of our Lord's Divinity and Incarnation, which the Apostles' Creed is content simply to affirm.

Perhaps the clearest way of approaching the subject will be to repeat, first, what were the two questions about our Lord's Nature which the Church had to answer; -

To consider secondly, what erroneous answers were suggested; -

1 Waterland ascribes the so-called Athanasian Creed to Hilary. 
And so arrive, lastly, at the true answers to which the Church was guided by the Holy Spirit.

\section{OUR LORD'S DIVINITY.}

First, then, How was the doctrine of Christ's Divinity to be reconciled with the doctrine of God's unity?

"Hear, O Israel : the Lord thy God is one Lord." Sucl was the doctrine thundered from Sinai, and reaffirmed by our blessed Lord. The doctrine that there is but One God is as essentially the basis of the Christian Creed as it is of the Jewish.

How then can we be asked to worship the Father and to worship the Son also? This was the first question.

Two erroneous answers were suggested. The ARIANs said Christ was divine, but in some inferior sense $;^{1} \mathrm{He}$ was the highest of all created beings, but still a created being. The Sabellians said, Nay, $\mathrm{He}$ is truly God; but God appearing in one of His three characters. ${ }^{2}$ God, viewed under one aspect, we call the Father; God, under another aspect, we call

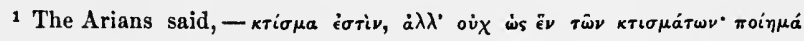

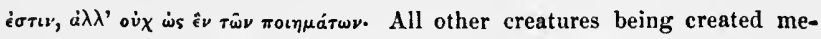
diately through the Word, whereas the Son was created immediately. Ath. c. Ar. ii. 19.

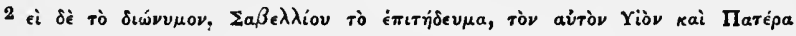

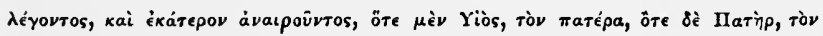
Yiòv.-Ath. c. Ar. iv. 9. 
the Son ; God, under a third aspect, the Holy Ghost. We must not conceive of three distinct persons, but of one and the same Divine persons standing in three distinct relations to us.

Thus were men driven into one or other of two lamentable errors by the difficulty of reconciling the worship of Christ with their belief in one only God.

Then stood forth Athanasius to vindicate the true meaning of God's Word, and to give the Church its key.

He saw clearly that Christ spoke of Himself as one with the Father - "I and My Father are one," 1 praying that His Church might be one as $\mathrm{He}$ and $\mathrm{His}$ Father were one; - "As Thou, Father, art in Me, and I in Thee;" 2 "He that seeth $\mathrm{Me}$, seeth Him that sent $\mathrm{Me} ; "$ "He that receiveth $\mathrm{Me}$, receiveth Him that sent Me."

Thus distinctly did Christ claim to be one with $\mathrm{His}$ Father. He and His Father essentially one God. This, on the one hand, against the Arians.

On the other hand, as against the Sabellians, Athanasius no less clearly set forth how Christ claimed a distinct personality: The Father sends the Son (John v. 36, 37 ; vi. 38, 39). The Son leaves the Father and returns to Him (xvi. 28); the Son offers Himself to the Father (Heb. ix. 14); the Father loves the Son, the Son loves the Father (John iii. 35; 
v. 20); the Son prays to the Father (xvii.) ; intercedes with the Father (Heb. vii. 25; 1 Jolnn ii. 1). ${ }^{1}$

These Scriptures would be absolntely unmeaning if by "Father" and "Son" were meant one person, capable of being regarded in either of two characters. ${ }^{2}$

Thus, then, Athanasius showed that we are compelled to believe two truths :-

(1.) That the Father and the. Son are two perfectly distinct persons ; and,

(2.) That the Father and the Son are essentially one God.

One in essence, ${ }^{3}$ two in personality. This was the definition which the Council of Nicæa (A. D. 325) accepted.

The thind part of the Creed, extending the doctrine to the Holy Ghost, was added fifty years later (at the Council of Constantinople, A. D. 381).

In the so-called "Athanasian Creed" of the Western Church, composed probably in the fifth century, ${ }^{4}$

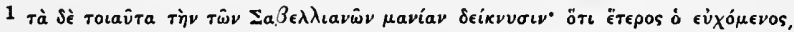
êтepos ò ėтакоúwr. - Ath. de Sent. Dionysii, 26.

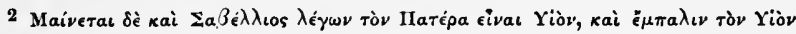

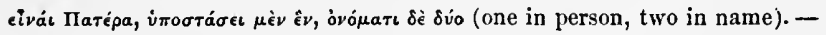
Ath. c. Ar. v. 25.

3 Essence is the exact equiralent of the word used by Athanasins. If the Western Church had had the word in those days, doubtless it would

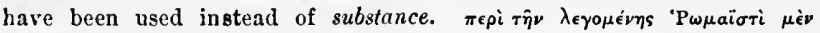

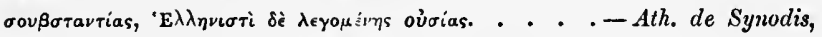
28. For a definition of Personality, see p. 89.

4 Waterland dates it between 430 and 450, and suggests Hilary of Arles as its author. 
the doctrine of the Trinity was yet more completely set.forth. Let us receive it reverently : we shall find it a key to Holy Scripture, and a safeguard against speculation, for which we cannot be too grateful.

The doctrine of the Trinity deals with matter beyond reason, but there is nothing in its statement contrary to reason. It would be contrary to reason to say that three persons were one person. But this the Athanasian Creed expressly forbids us to say. We are not to "confound" (or merge into one) the three Persons. Nor, on the other hand, are we to " divide the substance" (or essence) of God."

It asserts that three distinct Persons are one in essence.

This could not be true of three human persons. But of three Divine persons it may be conceived to be true, and it is true, that they are personally distinct, in essence one.

The Athanasian Creed then enumerates the several epithets applied in Scripture, - "uncreate," 2 " incomprehensible" (i. e., illimitable), " eternal," "almighty," "God," and "Lord ;" - and declares that

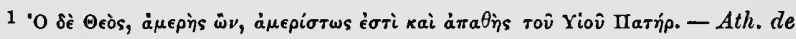
Decretis Nicance Synodi, cap. xi.

2 St. Augustine clearly asserts that there can be no middle term between "created" and "uncreated." "Liquido apparet Ipsum factum non esse per quem facta sunt omnia. Et si factus non est, creatura non est : si autem creatura non est, ejusdem cum Patre substantiæ est. Omnis enim substantia quæ Deus non est, creatura est; et quæ creatura non est, Deus est." - Aug. de Trin. i. 6. 
to each one of the three Divine Persons, severally, all these epithets may be applied. Yet the three Persons so spoken of are but one Divine Being. Then that which differences each Person is stated. The Father is self-existent. The Son is begotten of the Father, not in time but from all eternity. ${ }^{1}$ The Holy Ghost proceedeth from the Father and the Son. ${ }^{2}$

\section{OUR LORD'S INCARNATION.}

We must now proceed to the second great question which perplexed the minds of Christians, and treat it as we treated the former, considering, first, the question to be answered; secondly, the false answers suggested; and thirdly, the true answer.

Granting the doctrine of the Trinity, men found a difficulty in the Second Person's incarnation. How could $\mathrm{He}$ be at once the Son of God and the Son of Man?

The Church had not as yet defined the doctrine of the Incarnation, and consequently two erroneous answers were advanced. The Nestorians said "That which was born of Mary was a human person merely, but into this human person so born, the Divine Person of the Word entered," - a grievous error (though Nestorius seems not to have foreseen

1 "Begotten, not by the will of the Father, but by the necessity of the

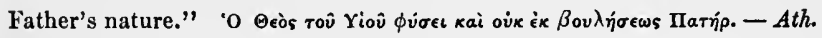
c. Arian. iii. 62.

2 See extract from Gregory Nazianzen, p. 97. 
its dangerous consequences); for were it so, then Christ was not properly "a second Adam," but rather one of the "old Adam" into whom the Second Person entered, even as the Third Person enters into us, by way of inspiration. Whereas Holy Scripture distinctly teaches us that $\mathrm{He}$ who was born of the Virgin Mary had "come down from heaven" (John iii. 13), and "come forth from God" (xvi. 27) - a Divine Person assuming a human nature in addition to His Divine nature.

No less grievous (though in a different way) was the opposite error of Apollinaris and Eutyches. They believed that the Son of Mary was most truly the Son of God, and that from the moment of conception ; but, so far sound, they fell into error in explaining away our Lord's humanity. Apollinaris taught that Christ had no human mind, the Deity in Him supplying the place of mind. ${ }^{1}$ Eutyches went farther, and taught that the whole human nature which the Second Person took from Mary was deified, ceasing to be human, merged and lost in the Divine Nature, as a drop of wine would be lost in the ocean. Thus both deprived us of all the comfort of our faith in Christ's perfect humanity.

1 Mentem, quâ rationalis est anima hominis, defuisse animæ Christi, sed pro bâc ipsum Verbum in eo fuisse dixerunt. - Aug. de Hares. 55. Apollinaris allowed that Christ had a human soul, but he distinguished between

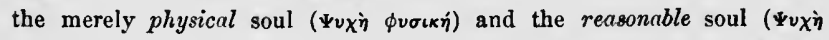
$\lambda$ 入yı $\dot{\eta}^{\prime}$ ), and denied to Christ the latter, saying that the Divine Logos took its place. 
If Christ had no human mind, or if His whole human nature were transubstantiated into the Divine, then all that temptation, all that conflict with evil, all that agony and effort, all that "prayer and supplication, with strong crying and tears," all that "learning of obedience by the things which he suffered," - all was unreal (for the Divine Nature is impassible). And what then? Why this: that we have no high-priest who can be touched with the feeling of our infirmities, in all points tempted like as we are, though sinless. Ah! what a loss to us if this were really so!

But, thank God, it is not so. And the Church was guided so to define Christ's nature and incarnation as to preserve to us the faith to which we eling. ${ }^{1}$

One short verse in our Athanasian Creed sums up the clear teaching of Scripture on this point: "Perfect God and perfect Man." We must mark well and try to grasp this double truth : -

(1.) He who was born of a woman, and suffered and died on the cross was perfect God (therefore we are redeemed).

(2.) He who is now at God's right hand, making intercession for us, is perfect man (therefore we have a Mediator).

1 The Apollinarian heresy was condemned at the Council of Constantinople, A. D. 381; the Nestorian heresy at the Council of Ephesus, A. D. 431; the Eutychian hercsy at the Council of Chalcedon, A. D. 451. 
On these two vital truths, that the Son of God assumed human nature to die for us, and in that same human nature is now interceding for us, hang all our hope and all our comfort.

We have endeavored to set forth briefly the doctrines of our Lord's Divinity and of His Incarnation.

To some the mystery of the Father and the Son being one God may seem greater than the mystery of the Son's Incarnation, and yet surely it is not so when we come to consider it. The difficulty of conceiving how two persons should be one in substance without loss of individuality, is not really greater than the difficulty of conceiving the converse, how two substances (the Divine and human natures of our Lord) should be combined in one person, each substance retaining its distinctness. Only this last appears to us easier of apprehension, because (as the Athanasian Creed reminds us) we are familiar with something of the same kind in ourselves, our body and soul forming one person, yet remaining distinct, as all true physiology teaches.

Indeed the facts which the Church asks us to believe about God's nature are not more mysterious than the facts which the philosopher is compelled to admit respecting his own nature. Science is obliged to acknowledge mystery. What is matter? A mystery. What is life or soul? A mystery. 
What is God's nature? We can only answer, "A mystery," albeit theological science, having the inestimable aid of revelation, has been able to define this last mystery with far greater precision than natural science has yet attained in defining those other mysteries.

Now let us gather up the four grand truths, which the first four Councils of the Church established, and which the Nicene and Athanasian Creeds embody. We are from childhood, so familiar with the words which convey them, that they enter into all our thoughts about our Lord; and sometimes, perhaps, we forget that. we owe them not to the Apostles' Creed, but to the Nicene, and still more to the Athanasian Creed.

I. The first truth is this : that Christ is God in the very highest sense, and may therefore be worshipped without any surrender or compromise of our belief that there is but one God.

II. The second truth is this: that though Christ be thus essentially one with His Father, yet is $\mathrm{He}$ personally distinct, standing to Him from all eternity in the relation of a Son. Therefore, while we believe Him to be God, we need not surrender our faith that $\mathrm{He}$ is our Intercessor.

III. The third truth is this: that it was none other than this eternal Son of God who was conceived and born of the Virgin Mary, thus becoming a second Adam, in whom mankind is created anew. 
IV. The fourth truth is this : that this human nature thus exalted to the right hand of God in the person of Christ remains a perfect human nature, not merged and lost in the Divine, but retaining all its human sympathies and all its human associations. ${ }^{1}$

1 Hooker sums up the four dogmas in four words: " $\dot{\lambda} \lambda \eta \hat{\eta} \omega \bar{s}$, re $\lambda \dot{\epsilon} \omega s$,

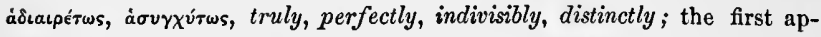
plied to His being God, and the second to His being Man, the third to His being of both One, and the fourth to His still continuing in that one Both." - Ecc. Pol. v. liv. 10. 


\section{CHAPTER III.}

THE DOCTRINE OF THE ATONEMENT.

$\mathrm{F}^{\mathrm{ROM}}$ the doctrine of Christ's Person we pass on to the doctrine of Clirist's work. And by the work of Christ we mean that portion of His work on which alone the Creeds insist, namely, His work of suffering and death. It is most noticeable that both the Apostles' and the Nicene Creeds pass at once from the mention of the Nativity to the mention of Sufferings and Death. All between,- Christ's Baptism, Ministry, Teaching, Miracles, - drop out, and find no mention in our Creeds. The essential work, on which our faith is centred, is His Death. On this let us now fix our thoughts.

The death of Christ! When we wish to speak of this - we poor sinful men speaking of an act of God on which depends our eternal weal or our eternal woe it may well seem to many that any mere doctrinal statement of it must be cold and hard even to profaneness! All our words should shape themselves into prayers or hymns of adoration; our only attitude should be that of worship; and indeed we cannot be too mindful that "to speak of these things 
merely in the way of explanation, without stopping to dwell more fully on the thoughts and feelings which they ought to awaken, may seem almost to encourage that dangerous habit of listening unconcernedly with unmoved consciences to truths which should be most humbling and most awakening." 1 Still it is not less true, that the more we try to understand God's deeper dealings with mankind, the more we shall know of His goodness and wisdom, and the more reasonable will be the service that we render Him. So, certainly, seems St. Paul to have thought when he wrote, "I will pray with the Spirit, and I will pray with the understanding also: I will sing with the Spirit, and I will sing with the understanding also." 2

With all reverence then let us seek to enter into the deeper revelations of God's Word respecting that Death of Christ in which the Creeds intend us to find His chief work for man.

And this is first to be observed, that any view of Christ's redeeming work which finds it in His life, rather than in His Death, is out of harmony with the

I Arnold's Sermons on the Epistle to the Romans.

21 Cor. xiv. 15. How nobly does Bishop Butler express his conviction that Scripture is rational, though not rationalistic: "Let reason be kept to: and if any part of the Scripture account of the Redemption of the world by Christ can be shown to be really contrary to it, let the Scripture, in the name of God, be given up; but let not such poor creatures as we go on objecting against an infinite scheme, that we do not see the necessity or usefulness of all its parts, and call this reasoning." - Analogy, ii. 5 . 
Creeds and with Scripture. For our Creeds are here in accord with the four Gospels. Of the space occupied by the Gospel narrative about one third is given ta the events of that single week of our Lord's passion. A supreme importance is clearly attributed to our Lord's sufferings and death, overshadowing all else recorded of Him.

This marks our Lord's work for man as a work that stands alone in all history. His work was not merely one of the onward steps in the moral progress of the world; - it was an act of Divine power, mysteriously accomplished in dying, and belonging to all time. And in truth this impression left on our minds by the prominence given to His Death in the four narratives is confirmed by a more careful study of our Lord's own language about the purpose for which $\mathrm{He}$ had come into the world.

For what was our Lord's view of that purpose? Was it to enlighten mankind? Yes, but not chiefly; "I have many things to say unto you, but ye cannot bear them now." Christ seemed content to postpone the further unfolding of doctrine, and to devolve it on the Spirit of Truth, who after He was gone would "guide them into all the truth." What was His purpose then? Was it to found a new society, a spiritual kingdom, a Church? Yes; and yet He was content to leave behind Him in Jerusalem only eleven Apostles, only one hundred and twenty believers. If that were His chief purpose, then it had failed. 
What then was His purpose which through all His ministry He kept steadily in view, and did accomplish perfectly and entirely? For there was such a paramount purpose: "I have a baptism to be baptized with, and how am I straitened till it be accomplished!" 1 What was this one mighty purpose of which our Lord was so evidently conscious, and to which $\mathrm{He}$ was content to postpone all else?

From the very beginning of His Ministry it was plain to Him. Listen to His words at His first Passover: "As Moses lifted up the serpent in the wilderness, even so must the Son of man be lifted up." 2 Twelve months before the end He had said, "The bread that I will give is my flesh, which I will give for the life of the world!' 3 Six months afterwards, more plainly: "The Son of man shall be betrayed into the hands of men, and they shall kill Him." 4 Within three months of the end: "The Son of man came not to be ministered unto, but to minister, and to give His life a ransom for many." 5 And again, "I am the good shepherd: the good shepherd giveth His life for the sheep." "Therefore doth My Father love Me, because I lay down My life." 6

To the last He kept this mysterious purpose steadily in view, but (let us mark it well) not without much inward conflict and agony as the time approached.
1 Luke xii. 50.
8 John vi. 51.
5 Matt. xx. 28.
2 John iii. 14.
4 Matt. xvii. 22.
6 John x. 11, 17 . 
"Now is my soul troubled: Father, save Me from this hour! But for this cause came I unto this hour." 1

To the last He forbade His Apostles to defend Him; and why? because His sufferings were predestined, - a necessity laid upon Him. "Put up thy sword into the sheath; the cup which My Father had given Me shall I not drink it?" “Thinkest thou that I cannot now pray to My Father, and He shall presently give me more than twelve legions of angels? But how then shall the Scriptures be fulfilled that thus it must be?" 2

Thus it must be. This one thought sustained Him to the last. Not till He had drained that cup of appointed suffering to the uttermost did He allow himself to say with His expiring breath that the work $\mathrm{He}$ had come to do was finished.

But all through these months and years of preparation the purpose was fully known to Himself only. Not till all was over, in the calm leisure of those forty days, did He open His Apostles' minds to understand it. Then at length they perceived that in Moses and all the prophets it was foretold that the Messiah was thus to suffer, and that all things written in the Law and in the Psalms could only so be fulfilled. Not only had Moses in the whole sacrificial system of the Law prefigured the Messiah's sufferings, not only had

1 John xii. 27.

2 Matt. xxvi. 52-54. 
Psalmist and Prophet portrayed them with marvellous exactness; but Christ Himself entered upon His ministry with a distinct consciousness that this was above all else the task that was laid upon Him, - the task of suffering.

The first thing, therefore, we have to note about the death of Christ is this, that it was predestined, and from the first contemplated by Christ as the appointed purpose of His mission.

And now we proceed to observe a second point of the greatest importance distinguishing our Lord's sufferings and death from those of any Saint of God of whom we have ever read.

Why that agony as it approached? We do not read of any such agony in the lives of the Saints. Brave soldiers meet death without fear, much more God's Saints. We are wont to believe that the holier a man is the less lis fear of dying; - some, a Ridley, a Latimer, have gone to a death of greater torture than the cross, with a smile on their face and cheerful words on their lips.

How was it then that $\mathrm{He}$ whose holiness was infinitely beyond theirs, whose conscience knew no sin, to whom the other world was not a matter of faith only, but an open vision, to whom death must have been a pure joy, an avenue of light restoring Him to the glory which $\mathrm{He}$ had with His Father before the world was, - how was it that $\mathrm{He}$, when the hour for 
dying at length approached, was filled with an exceeding sorrow, overwhelmed with dread, crushed to the earth with an agony of spirit which forced the blood from His brow, straining to the very uttermost His human powers of endurance, so that in His extremity of suffering $\mathrm{He}$ prayed that the cup might pass from Him, yea felt as though His Father had forsaken Him? How was this? Why was this? What can all this mean? Surely, there is here some deep mystery, something unexplained about this death of Christ, making it totally unlike any other death of which we have ever read or heard!

Two points there are, therefore, in this death of our Lord, demanding explanation : one, that He ever viewed it as the predestined purpose for which $\mathrm{He}$ had come into the world; the other, this mysterious agony as it approached.

Thus by the mere narrative we have the conviction forced upon us that there was some profound mystery in the death of Christ.

If we turn to our inspired Scriptures, and search them for an explanation, our difficulty arises from the abundance, rather than from the scantiness, of their revelations. A thousand rays converge upon Good Friday ; a thousand allusions in sacrificial type, in prophecy, in apostolic doctrine, throw their light upon the Death of Christ, and help to reveal its mysterious significance. 
In the Second Part of this work will be found an analysis of Holy Scripture's teaching on this mysterious subject.

In this chapter we will endeavor to collect these scattered lights into one focus, and to exhibit, as clearly as may be, an image of the doctrine so obtained. If the result appear to us to be more in harmony with the teaching of the first four centuries than with that of the last three, we need not therefore mistrust it. Let us rather embrace it with all the more confidence, remembering that our Church's appeal in matters of doctrine is to Scripture, interpreted, in case of doubt, by the ancient Fathers and Councils. ${ }^{1}$

Before we endeavor to set forth the Church's earlier interpretations of Scripture, it may be well to state very briefly the view of the Atonement which has popularly prevailed in the last three centuries.

God's word had declared, and God's justice required, that sin should be punished; but God's mercy willed that man should be spared. The difficulty was met by God giving His Son to take upon Him man's nature, and suffer punishment in man's stead.

1 See the appeal to "the mind and purpose of the Old Fathers" in the preface to the Prayer-book. See also the Statute of 1 Eliz. i. 36, in which, among the authorities which are to determine heresy, we find the first Four General Councils. In the canons of 1571 , preachers are to be guided by the Old and New Testament, "and what the Catholic Fathers and ancient Bishops have gathered therefrom." 
But what was the punishment which Christ suffered? Here the post-reformation divines diverge: some, with Calvin, ${ }^{1}$ dare to say that Christ's soul endured in His agony the pains of hell - the very pains which man would otherwise have endured; others, with Grotius, ${ }^{2}$ said No, it was not necessary that Christ should endure the self-same punishment that was due to man, but only so much as should suffice to serve as a demonstration of the Divine justice, and deter mankind from regarding sin as venial. ${ }^{3}$ Both parties agreed that Christ's sufferings and death were a substitutional penalty (poena vicaria), that $\mathrm{He}$ bore either the penalty or $a$ penalty for sin, the innocent for the guilty, and so saved the guilty from the punishment due to their sin. The obvious difficulty, How could it be just to punish the innocent and acquit the guilty? was solved (or supposed to be solved) by Luther's theory of imputation:- man's sin was imputed to Christ, and Christ's righteousness was imputed to man.

Such is the popular view of the Atonement in modern times.

It is surely open to grave objections :-

1. The theory that Christ bore the penalty of sin,

1 See Instit. lib. ii. c. 16, §10, quoted by Pearson, Art. V.

2 Defensio Fidei Catholica de Satisfactione Christi. 1617.

8 The theological term for this theory is Acceptilatio, a term borrowed by Duns Scotus from Roman law. Grotius disclaims the term, but clearly adopts the theory in substance. 
and thereby saved us from bearing it, leads to a dilemma which, if not fatal to it, is difficult to answer. For what was sin's penalty? If temporal death, then as a matter of fact we are not saved from it: if eternal death, then assuredly Christ did not bear it.

2. The notion of a transaction between the justice and mercy of God is artificial, and is dangerously apt to pass into the notion of a transaction between the Father and the Son, leading almost inevitably (as in the case of Milton, and, some would say, of Grotius) into Arianism.

3. The idea of imputation is also artificial, and finds no response in the instincts of a healthy conscience. That the Father should impute sin to His Son, regarding the all-holy One as guilty, is a theory shocking to the conscience, and unknown to the Church until the sixteenth century. ${ }^{1}$

4. The Scriptures, on which the theory of Vicarious Punishment is made to rest (notably Is. liii.; 2 Cor. v. 21; Gal. iii. 13) fail to sustain it.

In the sequel it will be my endeavor to show that Scripture constantly affirms that Christ "bore our sins;" but that He "bore the penalty of our sins,"

1 On the doctrine of imputation consult Bull, Examen Censura, xi. "De phrasi ipsâ quâ justitia Christi nobis imputari dicitur . . . certum est locutionem illam in Scripturis nusquam occurrere." The true and Catholic doctrine is that the "peccatorum non-imputatio fit propter justitiam Christi, tanquam causam meritoriam." See also p. 224, infra 
never. ${ }^{1}$ The central idea of the sin-offering in Scripture is not a vicarious punishment for sin, but a vicarious dying unto sin. Christ's death is uniformly spoken of as redeeming us, not from the penalty of sin, but from the sin itself, primarily.

5. The scriptural idea of God's Righteousness ( $\delta_{c}-$ kacoovir $\eta$ ) is changed into the Aristotelian idea of Retributive Justice.

Let this suffice by way of preface. Now let us seek to understand the deeper teaching of Scripture, as it seems to have been understood by the Fathers of the first four centuries.

We must go back, - not merely with Anselm and the Thomists to the Fall, - but with the Scotists and with Athanasius to the very beginning. The Incarnation (as Scripture teaches not obscurely) was designed before the foundation of the world. Possibly, even had there been no Fall, there would have been an incarnation, though no crucifixion. ${ }^{2}$ We may well believe it to have been part of God's original counsel in creating man, that $\mathrm{He}$, in whose image man was made, should, in the fulness of time, take upon Him this created nature, and therein realize and reveal the

1 For comments on the fifty-third of Isaiah, and other Seriptures which have been understood to imply that Christ bore the penalty of our sins, see pp. 186-191, 254, 265, 266.

2 Even the Iutheran Andreas Osiander (Professor of Theology at Königsberg, 1498-1552, quoted by Martensen, p. 172) admits this: "Etiamsi homo non peccasset, Deus tamen incarnatus esset, licet non crucifixus." 
highest good of a created being, which must ever consist in the joyous sacrifice of self-surrender unto God. We may well believe that $\mathrm{He}$ who created man designed from the very first thus to perfect him. (See Eph. i. 4.)

But be this as it may, all was changed by the intervention of sin. Sin - a mystery into which we can go no farther than to say that freedom of will in a created being seems to involve necessarily the possibility of $\sin ,{ }^{1}-\sin$ intervened, and mankind fell fell away from communion with God - fell therefore more or less under the dominion of evil, fell into corruption, and therefore fell under the inevitable law that what is corrupt must die.

Under these altered conditions would the Son of God still carry out His purpose of incarnation? It now involved entering the precincts of evil, and assuming a nature compassed with infirmity and liable to death. Nay, it involved more than this, as will be seen, if man was to be redeemed.

Would God's purpose hold under these altered conditions? Yes, "God so loved the world, that $\mathrm{He}$ gave His only begotten Son, that whosoever believeth in Him should not perish, but should have everlasting life." "God commendeth His love toward 11s,

1 " $\mathrm{Sin}$ is the disobedience of intelligent beings whom God has created, and whom He has endowed with a free will, which they can use or misuse." - Lightfoot on Colossians, p. 185. 
in that, while we were yet sinners, Christ died for us."

First and foremost let us mark this, and hold it fast, as against the extreme Calvinists : -

God's love was the moving cause, not the result, of what Christ did.

And next let us hold no less firmly, as against the Socinian, that it was not the life merely, but emphatically the death of Christ that redeemed us. As we have already said, ${ }^{1}$ no view of the Atonement can be considered scriptural which fails to discern a mysterious efficacy in the death of Christ.

The question which every doctrine of the Atonement is responsible for answering, so far as it can be answered, is this: "How did the death of Christ avail to redeem man?" And it must be answered, if at all, not from the reason of the thing, but from revelation.

There are, in the New Testament, three groups of phrases used to express the efficacy of Christ's death:

1. Of one group the key-word is propitiation, ìaruós.

2. Of another, the key-word is redemption, ȧmodú$\tau \rho \omega \sigma i s$.

3. Of a third, the key-word is reconciliation, $\kappa a \tau \alpha \lambda \lambda \alpha \gamma^{\prime} .^{2}$

1 See pages 54 and 55.

2 On these three cardinal words Bengel (on Rom. iii. 24) has an ex- 
If the central idea of the first group can be unfolded, the second and third groups will present no difficulty. It is the first group of words, all circling round the idea of propitiation, that carry us at once into the very heart of the mystery.

What is propitiation?

And, first, what was the heathen meaning of the word? Among the heathen the notion was that by the offer of some compensation God might be made willing to forgive sin. They knew that God was offended by sin; and having a very imperfect idea of His holiness, they thought $\mathrm{He}$ might be induced by compensation to relax His law, and so far lower His standard as to condone the sin.

Totally different from this is the scriptural idea of " propititation." In Holy Scripture God's perfect holiness and perfect love are revealed; and revealed (be it observed) not as opposed, but as in harmony one with the other, "Long suffering and of great mercy, . . . a and by no means clearing the guilty ; 1 "There is mercy with Thee, therefore shalt Thou be feared;" 2 "God is faithful and just to forgive us our

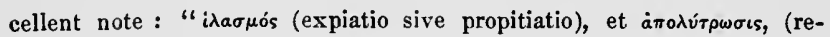
demptio) est in fundo rei unicum beneficium, scilicet restitutio peccatoris

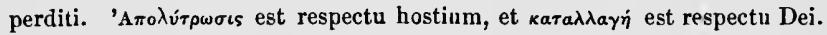

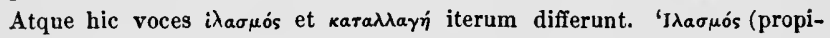

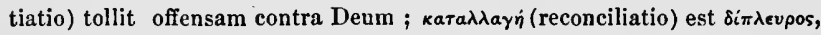
et tollit (a) indignationem Dei adversum nos, 2 Cor. v. 19, (b) nostramque abalienationem a Deo, 2 Cor. v. 20."

1 Ex. xxxiv. 6 ; Numb. xv. 18.

2 Ps. cxxx. 4. 
sins." 1 These are phrases that no heathen could have used. God's mercy is not like man's, a mere indulgence or relaxation of law, ${ }^{2}$ but something far more awful. By an inherent necessity of His nature, God cannot forgive without a satisfaction of the law of holiness; when the law of holiness is satisfied, $\mathrm{He}$ is "faithful and just" to forgive us.

Now what is this law of holiness which must be satisfied? "The soul that sinneth it shall die;"3 "In the day that thou eatest thereof thou shalt surely die ;" 4 "The wages of sin is death." 5

And what is the meaning of this law? It means this, that there is an absolute incompatibility between God and what is sinful. Therefore the sinner must either die unto God, or die unto sin. If he remain sinful, he dies unto God, - dies eternally. If he die unto $\sin$, he ceases to be sinful, and may live unto God.

It may be well to pause a moment on these phrases, "dying," in the sense of ceasing to live unto God," and "dying unto sin." They are profoundly significant. They seem to imply that a man can only pass from one kind of life into another kind of life by

\section{John i. 9.}

2 It is one of the capital faults of Grotius's famous treatise, which so fascinated the English divines of the seventeenth and eighteenth centuries, that he makes God's pardon a " relaxatio sive dispensatio legis ; " and speaks of God's justice as "relaxabilis."
8 Ezek. xviii. 4.
4 Gen. ii. 17.
6 Rom. vi. 23. 
dying, - by going through a process of dying. If he pass from his higher kind of life (in communion with God) into his lower kind of life (cut off from this communion), he "dies" in the sense of ceasing to "live unto God." If he is to pass from that lower life (which is out of communion) into the higher life (which is in communion with God), it must also be by dying - "dying unto sin.". There is (so to speak) a dying downward, and there is a dying upward.

Death - of the one kind, or of the other kind there must be; for the law of holiness is absolute;there can be no communion between God and what is sinful.

Death of the first kind is sometimes spoken of in Scripture as inflicted by God's wrath, by which is meant that it is necessitated by His awful holiness.

Death of the latter kind seems to fulfil the scriptural idea of propitiation or expiation, averting wrath by satisfying the law of holiness in that only other way in which it can be satisfied. Thus we seem to arrive at a definition of the scriptural idea of "propitiation :'

It is such a dyiny unto sin as shall satisfy the law of holiness, and enable God to forgive the sinner.

We may now go a step farther.

If propitiation require a dying unto sin, can we, in our own strength, thus propitiate God?

Will repentance suffice? Repentance can only lead 
to effort against $\sin$ for the future; it cannot undo what is once done, or destroy our responsibility for it ; nor can it regenerate our sinful nature. 1 Repentance, therefore, does not come up to the idea of dying unto sin. All Scripture and all experience show that man in his own strength cannot die unto sin. According to St. Paul, the Law was given for this very purpose, to convince man that he could not of his own power die unto sin.

What then? If it must be done, and man could not do it, then, if done at all, it must be done for us.

And it seems to have been the purpose of all those sin-offerings under the Law to impress on man this twofold truth: First, that there could be no propitiation witlout a dying unto sin. This found expression in the bloodshedding; without shedding of blood there was (under the Law) no remission. And, secondly, that the dying unto sin must be vicarious, man being himself unequal to it. This was seen in the bloodshedding being, by way of symbol, on an altar.

But did those sacrifices really avail to expiate $\sin$ ? Clearly not; the Epistle to the Hebrews (x. 4) forbids the thought. They only pointed onward to One

1 Both Athanasius (de Incarn. \$ 7 ) and Anselm (Cur Deus Homo, 1, 20) discuss this question, and show that repentance is in itself unarailing. The reasons given in the text are those of Athanasius. Butler (ii. 5) shows from analogy that reformation does not prevent the consequences of past wrong-doing. 
who should die unto sin on man's behalf, and so make a real expiation.

And who was equal to this? Very beautifully does St. Athanasius lead up to this; it must be an act of Divine power, for none but God can undo what is done, ${ }^{1}$ and yet it must be accomplished in man's person, for it is man who has need to die unto sin. Who then was equal to it, - equal to this effort of grace, for the recovery of man? Who but $\mathrm{He}$, who in the beginning had created all things out of nothing, the Word of God? He only could sum up all mankind in His own Person, die unto sin for all, and so satisfy the eternal law of His own and His Father's holiness.

That Christ, the sinless One, did thus die unto sin, is the express teaching of Scripture: "In that $\mathrm{He}$ died, He died unto sin once." (Rom. vi. 10.) He was " made sin for us, who knew no sin, that we might be made the righteousness of God in Him." (2 Cor. v. 21.) "What the law could not do, in that it was weak through the flesh, God sending His own Son in the likeness of sinful flesh, and for sin, condemned (doomed to death) $\sin$ in the flesh." (Rom. viii. 3.)

What is the meaning of these Scriptures? That Christ was punished by His Father for mankind's sin?

1 Annihilation, even of matter, is as great a mystery as creation. How modern science is illustrating this, in the sphere of matter, by its doctrime of the conservation of energy! 
Not for one moment! But the infinitely deeper truth that Christ gathered up into His own Person all mankind, laden as they were with sin, and, with the consciousness of their sin upon His heart, consummated that dying unto sin which they were in themselves powerless to effect. In this sense Christ's death may be rightly termed vicarious, - meaning by the word, not that $\mathrm{He}$ died as a substitute, but rather as a sponsor for all.

That this is St. Paul's own interpretation of his words (that in Christ's death mankind - he does not say "were saved from dying," but — "died") will be plain to any one who reads carefully Rom. vi. 1-11. The pervading thought of those eleven verses is that we all died with and in Christ: — " $\operatorname{died}^{1}$ unto sin;" were baptized into His death;" "were buried with Him ;" "planted together with Him in the likeness of His death;" "our old man crucified with Him, that the body of sin might be destroyed."

These phrases, and especially the last, seem to give us the very key to the doctrine of the efficacy of Christ's death that we are seeking:- our old man, our fallen nature, was crucified with Christ. For, if so, then that law of holiness, that "what is sinful must die," was fulfilled and satisfied ; and so God was enabled, without lowering the standard of holiness, to forgive the sinner.

1 It is much to be regretted that the aorist tense is changed in our translation into the perfect. 
God forgives sinners, because in Christ they die unto sin. In themselves they are powerless to do it in Christ they do it. But when we say that in Christ they do it, we mean two things: we mean that mankind as a whole did it completely; and that individuals do it more or less. In Christ the whole race died unto sin as completely as in Adam the whole race had died unto God completely. But what is true of the whole race completely, is not completely true of each of the individuals who make up that race, in either case. For neither in Adam did every individual man die utterly to God, nor in Christ does every individual die utterly to sin. It depends on the will of the individual (concurring with God's grace) how far he appropriates what Christ has done.

Thus, this "dying unto sin" is at once an act of Divine power, accomplished, once for all, sufficing for the whole race, and at the same time an act in which the individual man's free will must, by God's grace, concur, else it will not be for him availing.

This seems to be precisely what St. Clement of Rome meant to express in those words which Bishop Bull desired to have inscribed in letters of gold : "Let us look to the blood of Christ, and consider how dear unto God is that blood which won for the whole world the grace of repentance." The Death which propitiates, is Christ's ; the repentance which appropriates a share in that death, is man's. 
We may sum up all that has now been said about the scriptural meaning of Christ's propitiation (i $\lambda a \sigma-$ rós) very briefly:-

When Holy Scripture says that "Christ died for

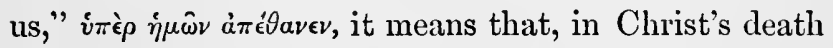
unto sin, all mankind quoad sufficientiam, and all who are in Christ quoad efficientiam, died unto sin : and so the law of holiness was satisfied.

Three points may seem to need further elucidation, before we dismiss the subject of propitiation.

1. The Rationalist says, "You speak of an act of $A$ being accepted as an act of $B$; this is to my mind a fiction." The Calvinist accepts this way of putting it, but insists that it is no fiction. The concession is a fatal error; he will never refute the objection while he admits the assumption on which it rests. The true reply is that both the Rationalist and the Calvinist seem to forget of Whom they are speaking; it is not the case of $a$ man dying for other men ; but it is the Man, the representative Man, the Divine Head of the race, $\mathrm{He}$ in whose Image man was originally created. ${ }^{1}$ Ever since that first creation, between

1 "Not $a$ man, but the man :" - to a Pelagian this language will carry no meaning; but to the Augustinian - to all who so far believe in continuity and traducianism as to accept the Scripture that "by one man sin entered into the world," - this doctrine of the organic unity of mankind will be the key to that other Scripture that "all died in Christ." It was a profound saying of Stahl (quoted by Olshausen, on Rom. v. 12), that "In Adam the original material of Humanity, in Christ the original idea of it 
mankind and the Christ of God, there has been a vital connection full of mystery. When the mystery of the Redeemer's Person is borne in mind, it almost ceases to be a mystery that His death should affect the whole race. Every act of Christ must vibrate through humanity! If, in a plant, an injury to the root is felt in every branch; if, in an army, it is not the Captain only who conquers or is conquered, but every soldier with him; if, in all organic societies, when one member suffers, all the members suffer with it; if, in the great family of mankind, the fall of one entailed the fall of all; then is it a strange thing that St. Paul thus judged, that if Christ died for all, then all died in Him?

The efficacy of Christ's death can never be understood unless it be thus viewed as a Divine act of spiritual power, in which every member of the race must in some way - may to his infinite blessing - participate.

2. And this leads us to our second corollary. How

in the Divine mind, have a personal existence. In them is Humanity concentrated, and therefore is Adam's sin the sin of all, and Christ's offering an universal atonement." So Bishop Bereridge (quoted by Wilberforce on the Incarnation). "It was not any human person in particular, but the human nature that Christ assumed into His sacred Person." And so the Athanasian Creed teaches that Clirist's incarnation was "not the conversion of Godhead into flesh, but the taking of manhood into God." In Olshausen's Commentary on the Romans, and in Archdeacon Wilberforce's Doctrine of the Incarnation, this line of thought is admirably worked out. See also Hooker, Ecc. Pol. v. lii. 3. 
could the expiation of Christ's death be retrospective as well as prospective? This difficulty, like the last, vanishes, when we remember the mystery of the Redeemer's Person. The acts of the Son of God belong, not to time only, but to eternity also; the Lamb was slain from the foundation of the world. The holy men of old were conscious of One whose Being was in the bosom of God, capable of entering into closest fellowship with their sufferings. In the faith that He would be one day revealed, they lived and died. Abraham rejoiced to see His day, and he saw it and was glad. Nay, man's mystical union with Christ may, for aught we know, be effectual even where there is no consciousness of it. Our Lord's own words seem to imply it: "Lord, when saw we Thee. .... Inasmuch as ye have done it unto one of the least of these $\mathrm{My}$ brethren, ye have done it unto Me." With a true instinct Tertullian speaks of an "anima naturaliter Christiana." We know that the repentance of the Ninevites was accepted; may we not say that it was accepted for Christ's sake? ${ }^{1}$

3. And a third corollary is needed, already in - part anticipated. If Christ died unto sin once for all and perfectly, and if all who are in Him died unto $\sin$ in His death, then why are there the motions of sin yet living within us? Alas! bitter experience

1 Justin Martyr and Clement of Alexandria would have said the same of not a few of those Gentile sages who "fores Veritatis pulsabant." 
teaches us that the believer's death unto sin is neither perfect nor once for all accomplished. How and why is this? For the simple reason that the believer's faith in Christ, and self-dedication to Christ, are neither perfect, nor once for all accomplished. Therefore all we can say is this, that as Christ died unto sin once for all and perfectly, so the believer dies more or less unto sin in Him, and has to "work out his own salvation with fear and trembling."

But while we confess this, we may add with deepest thankfulness that Christ's work was nevertheless perfect, and that God accepted Christ as mankind's Sponsor, ${ }^{2}$ and surety; and on this security - thus safeguarding the law of holiness - forgave us completely. The believer's justification is therefore complete, though his sanctification must be gradual. Thus Christ's deatlı in all ways fulfilled the scriptural

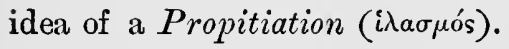

We have now discussed the first and most difficult of the three words by which Scripture sets forth the efficacy of Christ's death, - Propitiation.

If we have at all succeeded in defining it, our discussion of those two other words - Reconciliation and Redemption - need not occupy much space.

For what is the Reconciliation? It is the result of

1 'Eyruos is the word in the Epistle to the Hebrews '(vii. 22), - a most helpful expression. 
the Propitiation as it regards our relation to God. And what is the Redemption? It is the result of the Propitiation as it regards our relation to the Evil One. Thus Propitiation is the fundamental thing, and Reconciliation and Redemption are the results.

Our very language bears witness to this in the case of Reconciliation; for the old Saxon word atonement, which etymologically is the exact equivalent of reconciliation - at-one-ment, or a setting at one, - has by a true instinct been deepened into the idea on which it rests, and has come to carry with it the idea of propitiation or expiation.

And so, again, the word Redemption, which etymologically means deliverance by payment of money, has been deepened by its application to this mystery in Holy Seripture, and drawn aside into sacrificial associations, meaning deliverance by the shedding of blood, thus also carrying with it the idea of propitiation or expiation.

But some further definition of each of these words, as applied to the results of Clirist's death, may be useful.

And first this reconciliation, is it a reconciliation of God to man, or of man to God?

We have been often reminded by recent writers ${ }^{1}$ that in Holy Scripture it is always spoken of as a reconciliation of man to God; and much complaint is

1 Writers of the school of Maurice, Robertson, M'Leod Campbell. 
made that the second of our Thirty-nine Articles inverts the phrase, and speaks of Christ having suffered "to reconcile His Father to us."

Now, it is quite true that in Holy Scripture this way of putting it does not occur. The enmity is on man's part, not on God's; therefore it is man who needs to be reconciled: "Be ye reconciled to God;" "God was in Christ reconciling the world to Himself ;" "when we were enemies we were reconciled to God." With God there "is no variableness nor shadow of turning;" it is in man that alteration is needed. This is most true; and yet, oh, is it not equally true that there is deep down in our hearts a yearning desire for some change on God's part, that He will turn and be gracious, and a profound conviction, which Scripture encourages, that $\mathrm{He}$ must and will make the first move towards the reconciliation? While there is wrath, there must be need of the reconciliation of God to man. What is the solution? It is to be sought in the true conception of the wrath of God against the sinner.

What is the wrath of God? It is the restraining of His mercies. His mercies change not; they are ever seeking to flow forth on man; but they are barred and hindered by man's sin. Take away the sin, and the mercy of Him, who is ever yearning to be gracious, flows forth as of old. And this Christ did. Thus we see again how the Propitiation is the 
necessary ground of the Reconciliation, and how the reconciliation is essentially reciprocal - of God to man, and of man to God.

In this connection we may perhaps see our way to clear up our notion of that sadly-perplexed word Jusification. Keenly, almost fiercely, the point was contested between the Reformers and their opponents, whether the word meant a change in God or a change in man; whether it meant an accounting just on God's part, or a becoming just on man's part.

May not the solution be that the idea of justification, like the idea of reconciliation, is a reciprocal idea, involving both sides of one and the same truth?

For what is this truth? That in the Gospel there is revealed a righteousness of God - that is, a Divine gift of righteousness, a righteonsness not of man's making, but of God's giving. (Rom. i. 17.) ${ }^{1}$ And what is the essential meaning of this word right-

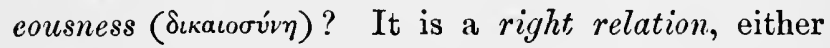
between man and man (as used by Aristotle), or between God and man (as used by St. Paul). Man had no poiver to put himself into this "right relation" to God. Christ did it. It was the gift of God. Christ's propitiation, as we have seen, modified both God's attitude to man (if we may venture so to speak) and man's attitude to God. In one

1 "Justitia Dei, non quâ justus est, sed quâ induit hominem, cum justificat inpium." - Aug. de Spir. et Lit. 9. See p. 215, infra. 
word, it established " a right relation" between God and man; and this is what St. Paul means by

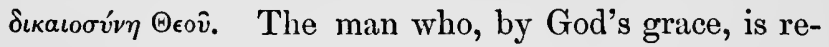
stored to this right relation to God, is said to be $\delta \iota \kappa a \iota \omega \theta \epsilon$, justified. And God's act in restoring man

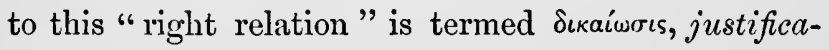
tion.

If this be a true account of the word "justification," then we perceive at once the clear distinction between justification and sanctification, - which both the Tridentine divinity and the Rationalistic divinity are in some danger of confusing. ${ }^{1}$

Justification is that establishment of a right relation between God and man, which was effected once for all by Christ's death, and which may be apprehended once for all by faith.

Sanctification is that growth in holiness through the influence of the Holy Spirit, which must surely, though it may be slowly, follow justification.

We perceive, too, the very close connection of Justification and Reconciliation. The latter word is generally used by St. Paul when he is speaking of the

1 The Roman Catholic view making Justification a condition of the soul ingendercd in man (habitus infusus), and the Rationalistic view, which makes it merely a more cxcellent morality, err alike in regarding it as an incomplete thing, having its degrees; whereas, the truly evangelical view of St. Augustine sees in Justification a lifting of the ehild of God once for all, and completely, into a right relation to his heavenly Father. The gradual after-growth is Sanctification. 
result of Christ's work as affecting the relation of mankind to God; the former, when speaking of the appropration of this by the individual.

We may now pass on to the discussion of the remaining word Redemption.

We have already said that this word serves to express the effect of Christ's propitiation as it regards our relation to the Evil One.

It has been said that the Church for a thousand years, that is down to Anselm's time, believed that Christ paid a ransom to the Evil One for the deliverance of manl. This is unfairly said, especially of the Fathers of the first four centuries, although Origen unisled some of them into the error. Still it cannot but be admitted that divines, both ancient and nodern - led astray by the etymology of the Greek and Latin words for Redemption - needlessly perplexed the doctrine with the question:- "to whom was the ransom paid?"

The simple truth is that the Hebrew words ${ }^{1}$ usually rendered by the Greek word $\lambda v \tau$ pov $\sigma \theta a$, to redeem, by no means necessarily involve the idea of a ransom paid to any one by way of compensation. When God redeemed His people from Egypt, - and it was this

1 hat is the word used for God's redemption of His people from Egypt;

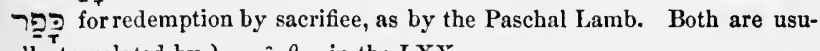
ally translated by $\lambda_{\nu \tau \rho o v} \sigma \theta_{a}$ in the LXX. 
great act which fixed forever the Israelite's conception of a redemption - there was no compensation paid either to the Egyptian bond-master or to the Destroying Angel, nor yet to God. And yet there was clearly the interposition of a $\lambda$ virpor, as a condition of the deliverance. God claimed as His own the life, or soul, or blood ${ }^{1}$ of those whom $\mathrm{He}$ delivered. And God required the blood of the Lamb as an acknowledgment of this.

We see from this how inadequate, and how misleading, is the English word ransom, as a translation of גúrpov. For our notion of a "ransom" is a compensation paid by the redeemer to some one else; whereas in the redemption from Egypt the $\lambda \dot{v} \tau \rho o v$ was claimed by the Redeemer as due to Himself.

Perhaps the only word in our language which at all corresponds to $\lambda$ úrpov, - and it need hardly be said how inadequate it is, - is the word homage ("I am thy man"), - a perpetual acknowledgment on the altar that the life and liberty they had received from God must be surrendered back to God. Such was the Hebrew idea of $\lambda$ úrpov.

We may now proceed a step farther.

This redemption of Israel from Egypt was a type of the redemption of mankind from bondage to the Evil One.

And as in the case of Israel, so in the case of man-

1 These words to an Israelite were synonymous. 
kind, God alone could effect it. And as in the case of Israel, so in the case of mankind, God required as the condition the homage of this self-surrender. And as Israel, so mankind were unable to fulfil the condition. What then? As in the case of Israel God "gave them the blood on the altar to make atonement for the soul" (Lev. xvii. 11), so in the case of mankind God gave the blood of Christ upon the Cross to make an atonement for our soul.

And this blood or life or soul of Christ, poured forth in perfect self-surrender unto His Father on be-

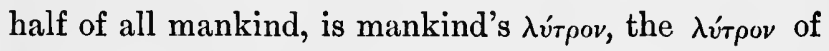
which Christ spake when He said that He came "to give His life a ransom for many" (Matt. xx. 28; Mark x. 45);-“a ransom," for we cannot avoid using the word, - "a ransom," inasmuch as it was the necessary condition of our deliverance from the bondage of Satan,- but not for one moment in the sense of being a compensation either to Satan or to His Father, but simply that expiation of sin, that dying unto sin, which (as we have seen) the eternal law of holiness required.

Thus we see in our conclusion, as we saw in our outset, how the idea of Redemption, as well as the idea of Reconciliation, has its root in the deeper mystery of the Propitiation.

There is yet one further mystery in Christ's Passion. It was a personal victory over the common enemy of 
the race, thereby benefiting the race forever. For the champion who maims and weakens the foe with whom all are struggling, is the benefactor of all. And Scripture reveals not obscurely that this was a part of Christ's achievement.

How the defeat of Satan was accomplished is not equally clear.

It may have been that the expiation of sin weakened the power which sin had given him.

It may have been that in cleaving a way throngh the dark valley and issuing unto light, and leaving that way - a living way - open to all believers, Christ virtually "destroyed him that had the power of death."

It may have been that in that garden of agony, and on that Cross of shame, there was a yet more direct and personal conflict with the prince of this world, whose hour it was, - too mysterious to be further revealed to us.

Whatever be the explanation, the fact of such a victory over the Evil One is declared in Scripture with abundant clearness : and the price of the victory no less clearly, our Champion's life-blood. "The good Shepherd gave His life for the sheep."

But this idea of Christ's championship and conflict with the Evil One lies apart from the doctrine of the Atonement, and is only introduced here by way of supplement, because no account of the mysterious effiacy of Christ's death is complete without it. 
The main purpose of this chapter has been to set forth the doctrine of the Atonement in harmony with the teaching of the first four centuries; in harmony with the instincts of a healthy conscience; and, above all, in harmony with the teaching of Holy Scripture.

The deep comfort of the doctrine who can tell? But it is not the comfort of sin being made less penal, it is not the comfort of being accounted righteous when we are unrighteous, it is not the comfort of being told that Another has borne for us the punishment that we deserved.

Infinitely deeper is the comfort of the Cross of Christ to those who know its power. It is the comfort of having our sense of $\sin$ so deepened that we learn to hate it with a perfect hatred. It is the comfort of a new hope and power within us, enabling us to crush and mortify sin more and more in all our members. Above all, it is the comfort of believing that however imperfect our dying unto sin may be, yet in Christ sin hath been altogether crucified; and the law of holiness being thus satisfied, if we are in Him, God is faithful and just to forgive us our $\sin$ now, and sanctify us perfectly hereafter. 


\section{CHAPTER IV.}

THE DOCTRINE OF THE THIRD PERSON OF THE TRINITY.

WE have been meditating in the two preceding chapters on the Person and work of our Blessed Lord, the second Person of the Holy Trinity, in His Incarnation.

In this chapter let us fix our attention prayerfully and reverently on the Third Person of the Holy Trinity.

Clear and distinct thought in matters of religion is a very great help to devotion. Devotion, by which we mean the soul's communion with God, is the allimportant thing, and $\mathrm{He}$ that is thus in communion with God, knows God with the best kind of knowledge ; for, as has been before observed, knowing God is an infinitely better thing than knowing about God.

Still, knowledge about God - having clear and distinct ideas about God, - in a word theology, is a great help, and therefore of much secondary importance.

Let our prayer be that our present meditation on the nature of God the Holy Ghost, as revealed in 
Scripture, may help us to enter into communion with Him, and know Him personally as our Friend and Comforter.

All do not so know Him. Christ said, "The world knoweth Him not;" and He gave the reason, "Because the world seeth Him not." (John xiv. 17.)

There are even professing Christians who do not realize to themselves His personality; who liave never got beyond the notion that by " the Spirit of God" the Bible means merely God's energy or influence upon the heart of man; merely a quality, or attribute, or power of God; just as we speak of the spirit of a man, saying, " $\mathrm{He}$ is a man of high spirit," or " He is a man of very humble spirit."

Now let us take the doctrine of the Holy Ghost as briefly laid down in the Nicene Creed, or rather in the Constantinopolitan Creed; for it was at the Council of Constantinople (A. D. 381) that this clause was thus enlarged. The Nicene Creed, as originally published at the Council of Nicæa (A. D. 325), had ended with the words, "And I believe in the Holy Ghost."

It was to refute the erroneous teaching of Macedonius ${ }^{1}$ that the doctrine of the Holy Ghost was

1 Macedonius fell into grievous error owing to his confusion of procession and generation. He denied the Divinity of the Holy Spirit. Ei $\mu \grave{\nu}$

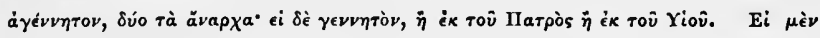

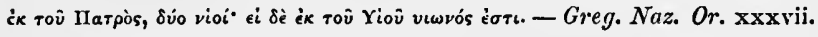
From such impiety the doctrine of the Procession saves us. 
added in the words which are to be the text of this chapter :-

"Ibelieve in the Holy Ghost, the Lord, and Giver of Life, who proceedeth from the Father [and the Son], who with the Father and the Son together is worshipped and glorified, who spake by the Prophets."

Observe how clearly we have here laid down -

The doctrine of His Personality,

The doctrine of His Divinity,

The doctrine of His witness in the world, that is the doctrine of Inspiration.

All three doctrines will demand our careful consideration.

But first it may not be amiss, by way of preparation, to endeavor to obtain a distinct notion of the meaning of the words personality aud person as used in speaking of the Holy Trinity.

What do we mean by a person?

Can we find any common property in mankind, in angels, and in the Divine Being, which defines our idea of personality, - some property which, belonging to all, serves to individualize each ? - for individuality is essential to our idea of a person.

Some have suggested Intelligence as the characteristic of personality. But the brute animals have intelligence in their degree. Intelligence, therefore, will not do.

Others have thought that personality was to be 
found in the Will. But it is not so. It would introduce confusion into our Theology, as the following admirable passage from Hooker shows: "Will, whether it be in God or man, belongeth to the essence or nature of both. The nature, therefore, of God being one, there are not in God divers wills, although Godhead be in divers Persons, because the power of willing is a natural, not a personal propriety. Contrariwise, the Person of our Saviour Christ being but one, there are in Him two wills, because two natures, the nature of God and the nature of man, which both do imply this faculty and power." (Eccles. Pol. V. xlviii. 9.)

Failing, then, to find that which truly individualizes the person in the Intelligence or in the Will, we seek it, with Bishop Butler and Locke, in that reflective, or self-referent faculty which we call Consciousness.

My consciousness is altogether my own ; all persons have it, and none can share it with another.

We may, therefore, best define a person to be an individual conscious being.

Now, let us apply this definition to the word Person as nsed in the doctrine of the Trinity.

Each Person in the blessed Trinity is an individual conseious Being. The Being (or nature or substance) is one and the same in all; and therefore (as Hooker shows) the Will is one and the same in all. 
It is the Consciousness which individualizes the Three Persons. Each Person is self-conscious, and conscious of a certain definite relation to the other two. The Father has the Being, with the consciousness of selfexistence : the Son has the Being, with the consciousness of being generated of the Father: the Holy Ghost has the Being, with the consciousness of proceeding from Both. It is this consciousness which seems to differentiate the three Persons.

Thus the nature of God is in this respect the converse of our nature. It is our nature to be one in person, manifold in substance (body, soul, and spirit); it is God's nature to be one in substance, manifold (that is, threefold) in person. God's substance being the original uncreated substance, whereon all other substance depends for its existence, ${ }^{1}$ ean only be one; but in this one substance there are revealed to us three distinct self-conscious agents, - the Father, the Son, and the Holy Ghost.

Being of one substance these three Divine Persons are not separable, as three human persons are separable, but ever united and inseparable, being one God.

Each of the three Divine Persons acts distinctly and individually ; for example, the Father creates, the Son redeems, the Holy Ghost sanctifies.

1 Descartes (Principia Philosophice, Pt. ii. 51) defines Substance, in this its highest sense, thus: "Per substantiam nihil aliud intelligere possumus, quam rem quæ ita existit ut nullâ aliâ re indegeat ad existendum. Et quidem substantia quæ nullâ aliâ re indigeat, unica tantum potest intelligi, nempe Deus." 
And yet in each of these acts, inasmuch as it is an act of God, all the Three Persons concur.

Thus in the beginning, "God created the heavens and the earth ;" but it was by the Word; and the Spirit moved upon the face of the waters. ${ }^{1}$

Again, it was Christ who " redeemed us to God by His blood;" but we read also that "God hath visited and redeemed His people ;" and it was " through the eternal Spirit" that Christ "offered Himself to God." 2

And lastly, St. Paul tells us that we are "sanctified by the Holy Ghost;" and yet our Lord speaks of sanctifying Himself that $\mathrm{He}$ might sanctify us; and in the same passage prays to His Father that $\mathrm{He}$ will sanctify us. ${ }^{3}$

These general remarks on the doctrine of the Trinity are premised for clearness' sake, that we may see distinctly what our Church has gathered from Scripture respecting the Holy Ghost; it is no less than this : (1) that $\mathrm{He}$ is a distinct Person; and (2) that $\mathrm{He}$ is is of the same divine substnce as the Father and the Son, concurring therefore in every act of the Father and in every act of the Son.

Now let us open the Bible, and observe for ourselves how its language necessitates this belief respecting the Holy Ghost.

\footnotetext{
1 Gen. i-13.

2 Rev. v. 9 ; Luke i. 68 ; Heb. ix. 14.

3 Rom. xv. 16; John xvii. 17, 19.
} 
I. First, as to His personality, we have Christ's own baptismal formula: "In the name of the Father, and of the Son, and of the Holy Ghost." The Spirit is here spoken of in precisely the same manner as the Son. We all confess that the Father and the Son are persons; this formula then obliges us to confess the same of the Spirit.

But other Scriptures also are unintelligible unless $\mathrm{He}$ be a distinct Person.

Take Rom. viii. 26 : "The Spirit maketh intercession for us with groanings which cannot be uttered." $\mathrm{He}$ intercedeth with whom? With the Father. How then can he possibly be a mere energy of the Father?

Eph.iv. 30: "Grieve not the Holy Spirit of God."

1 Cor. ii. 10 : "He searcheth all things, yea, even the deep things of God;" and xii. 11: "All these worketh that one and the self-same Spirit, dividing to every man severally as He will." Could His personality be more distinctly implied?

Acts xiii. 2: "The Holy Ghost said, Separate Me Barnabas and Saul for the work whereunto I have called them."

Chiefest of all we have our Lord's expressions concerning Him in His Last Supper discourse. (John xiv., xv., xvi.)

"The Comforter, which is the Holy Ghost, whom the Father will send in My name, $H e$ " (masculine 
in the Greek, though the word for Spirit is nenter) "shall teach you all things." "He shall testify of Me."

"If I go not away, the Comforter will not come unto you; but if I depart, I will send Him unto you. And when $\mathrm{He}$ is come, $\mathrm{He}$ will reprove the world. . . . He will guide yon into all the truth. For $\mathrm{He}$ shall not speak of Himself, but whatsoever He shall hear, that shall He speak. . . . He shall glorify Me, for He shall receive of Mine, and show it unto you."

What have we here? "A Person hearing, a Person receiving, a Person testifying, a Person reproving, a Person instructing." (Bishop Pearson.)

Some have said, "Yes, but so St. Panl personifies charity : - Charity suffereth long, and is kind; Charity envieth not, etc. ; - meaning, not that Charity is a person, but that persons who have charity act thus. So" (they say), "when the Holy Spirit is said to do this thing or that, we may understand that the Father doeth these things by virtue of His Holy Spirit, $i$. e., His power or influence."

Nay, but how if that which the Holy Spirit doeth is what God the Father could not be said to do? $\mathrm{He}$ intercedeth with the Father. How conld the Father intercede with Himself? He is sent by the Father. He receiveth from the Father.

Again, others have said, "He cannot be a Person because He is said to be given, and a gift is a thing." 
Nay, but what saith Holy Scripture of the Second Person? "Unto us a Son is given ;" "God so loved the world that He gave His only begotten Son."

II. Having shown that the Holy Ghost is a distinct person, we must now show that $\mathrm{He}$ is Divine, that is, of one substance with God.

And first, that Baptismal formula would be a blasphemy if it, were not so.

And again, Christ's language abont the sin against the Holy Ghost, as even more fearful than a sin against the Son of Man, would be utterly inexplicable, were He not very God. (Matt. xii. 32.)

And again, St. Peter spoke of lying unto the Holy Ghost, and lying unto God, as equivalent. (Acts v. 3,4 .)

And again, St. Paul's crowning argument against sins of the flesh is that our body is the Temple of the Holy Ghost (1 Cor. vi. 19), which he elsewhere expresses thus: "The temple of God is holy, which temple ye are." (iii. 17.) That St. Paul entirely and profoundly believed that Christ's baptismal formula implied the Spirit's Divinity as well as personality would be unanswerably proved by that one verse even if it stood alone, in which he gives the Corinthians his solemn blessing: "The grace of our Lord Jesus Christ, and the love of God, and the communion of the Holy Ghost, be with you all." (2 Cor. xiii. 14.) 
And that the Holy Ghost is of one and the same substance as the first Person of the Godhead, is proved by that passage which, however profound and unfathomable its mystery, yet to this truth at any rate bears evident witness: "The Holy Ghost shall come upon thee.... therefore also that Holy Thing which shall be boin of thee shall be called the Son of God." (Luke i. 35.) And again what one Scripture expresses by the words, "partakers of the Divine Nature" (2 Pet. i. 4), another Scripture expresses by the words, "partakers of the Holy Ghost." (Heb. vi. 4.)

But, assuming His Divinity as proved, it may still be asked, How is the Spirit to be distinguished from the Son of God? Does the only distinction lie in this, that the Second Person became incarnate, and the Third did not? Or have the Second and Third Persons been distinguished one from the other from all eternity?

The Fathers of the Church were led to observe that Holy Scripture continually expresses the relation of the Second Person to the First by the word begotten, but never once applies this word to the Third Person. The corresponding word applied to the Third Person is "proceeding," or some equivalent: "The Comforter .... even the Spirit of truth, which proceedeth from the Father." (John xv. 26.) So He is called the "Spirit of the Father." (Matt. $x$. 
20.) "The Spirit of Him that raised up Jesus from the dead." (Rom. viii. 11.) His Procession from the Father was on the strength of these and other passages ruled by the Council of Constantinople (A. D. 381). Afterwards the Western Church, - observing that $\mathrm{He}$ is also called the "Spirit of Christ" (Rom. viii. 9; Gal. iv. 6 ; Phil. i. 19 ; 1 Pet. i. 11); and that, in John xv. 26, our Lord said, "Whom I will send unto you from the Father;" and again in xvi. 7, "If I depart, I will send Him unto you ;" and again, that in $\mathrm{xx} .22$, He breathed on them, saying, "Receive ye the Holy Ghost," - inserted the word, "Filioque" (and from the Son) in the clause affirming His procession.

The Greek Church complains that this was done withont the authority of a General Council, and rejects the doctrine as inconsistent with the truth of God the Father's monarchy, i. e., that $\mathrm{He}$ is the one fountain of Godhead.

We reply that we maintain the monarchy; but, finding the Spirit spoken of in Scripture as the Spirit of the Son ${ }^{1}$ as well as of the Father, we say that $\mathrm{He}$ proceeds from Both - from the Father primarily, issuing from Him as from a source, and from the Son secondarily, as from one who transmits. He issues

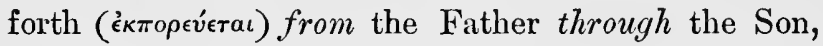
and so proceeds from Both.

1 Rom. viii. 9; Gal. iv. 6; Phil. i. 19; 1 Pet. i. 11; John xx. 22. 
To sum up: "The property of the Father is that $\mathrm{He}$ is unbegotten (self-existent) ; the property of the Son, that $\mathrm{He}$ is begotten ; the property of the Spirit, that He proceedeth." 1 All Three being one in substance, our Creed affirms that the Holy Ghost is "with the Father and the Son together worshipped and glorified."

We must now consider the further doctrine of the Creed, - that the Holy Ghost "spake by the Prophets."

This addition is in fact essential to our understanding of the doctrine; without it we should be left in utter perplexity. For whereas on the one hand we are forbidden to assign to the Holy Ghost any embodiment or organic form, ${ }^{2}$ on the other hand the Scriptures are continually attributing speech to Him. What then is the explanation? There is a passage in the Acts of the Apostles which supplies it at once. St. Paul tells the Ephesian elders (xx. 23)

1 The words are those of Gregory Nazianzen (Or. xxiii.): ióov dè, Matpòs

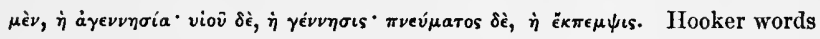
it thus: "The Persons of the Trinity are not three particular substances to whom one general nature is common, but three that subsist by one substance, which itself is particular, yet they all three have it, and their several ways of having it are that which maketh their personal distinction." (V. lvi. 2.)

2 Chrysostom, in his Homily on St. Matthew (iii. 16), is careful to remark that the Holy Spirit assumed not the nature, but the form only of a Dove ; and that only for the moment, in order to point out Jesus visibly. to the Baptist. 
that " the Holy Ghost witnesseth in every city, saying that bonds and afflictions" awaited him. How are we to understand this? The very next chapter makes all clear by describing how the Holy Spirit bore this witness: "There came ... a certain prophet, named Agabus; and .... he took Paul's girdle, and bound his own hands and feet, and said, Thus saith the Holy Ghost, So shall the Jews bind the man that owneth this girdle." (xxi. 10,11.) In the same passage we are told how the Holy Ghost spake by the mouth of Philip's four virgin daughters also.

Let us take another passage: in xiii. 2 we read: "The Holy Ghost said, Separate me Barnabas and Saul for the work whereunto I have called them." Again we ask how the Holy Spirit made Himself heard? Surely the preceding verse is intended to explain it. "Now there were in the Church at Antioch certain prophets .... and as they ministered to the Lord and fasted, the Holy Ghost said ...." clearly speaking by the mouth of those prophets.

We may very safely assume that whenever we read of the Holy Ghost thus "speaking," it is to be understood that He spoke by the mouth of those who had the Pentecostal gift of prophecy; and indeed we may reverently believe that it was for this very purpose that the Holy Ghost included prophetic utterance 
among His Pentecostal gifts to the Apostolic Church, viz, in order that $\mathrm{He}$ might thus have an organ through which to speak to men. These Prophets are frequently alluded to as a distinct order of the Christian Ministry. "God hath set some in the Church, first Apostles, secondarily Prophets, thirdly Teachers." 1 (1 Cor. xii. 28.) "He gave some Apostles, and some Prophets, and some Evangelists, and some Pastors and Teachers." (Eph. iv. 11.) And, therefore, in this same Epistle to the Ephesians (ii. 20), the Church is said to be "built on the foundation of the Apostles and Prophets;" where it is manifest that Christian Prophets are intended; for a few verses later the admission of the Gentiles is said to have been not made known in previous ages, "as it is now revealed unto His Apostles and Prophets by the Spirit."

Taking all this into account it seems highly probable that Justin Martyr, who lived in days when the existence of this Prophetic order was a familiar thought, meant to refer to it in the title which he nearly always gives to the Spirit, "The Prophetic Spirit." He seldom calls Him by any other name. And, if so, we may well believe that it was for the same reason, and intending to allude specially to the Christian order of Prophets, that the Council of Con-

1 All the Apostles were doubtless Prophets; but all the Prophets were not Apostles: therefore the two orders are distinguished. 
stantinople added the words, "Who spake by the Prophets."

Now let us proceed to notice the deep interest to us of this undoubted fact that the Apostles, and many of their contemporaries, possessed this special gift of prophecy, - were, in fact, the organs by which the Holy Ghost made His supernatural communications to that generation. For have we not here at once the proof, and an explanation, of the Inspiration of the New Testament Scriptures?

For what do we mean by the Inspiration of these Books? We mean, as Dean Alford well expresses it, - and it is the key to nearly all difficulty connected with the question, - we mean " that the men were inspired, and that the books were the result of that inspiration." In one word, we mean that the New Testament was written by men of the order of Prophets, by whose mouth, therefore, in the language of our Creed, "the Holy Ghost spake." The proof that the New Testament writers had indeed this extraordinary gift of inspired utterance is threefold. 1 . Christ promised it to them. 2. They tell us how that promise was fulfilled. 3. They claim credit for it in their subsequent writings.

1. Christ promised that they should have this Gift when $\mathrm{He}$ was gone.

Having in view the heavy responsibility of the task which $\mathrm{He}$ was intrusting to His immediate Dis- 
ciples, the task of publishing His Gospel, and recording for all ages the substance of His teaching, our Lord solemnly promised that $\mathrm{He}$ would qualify them for this task by a new and extraordinary gift; they should be " endued with power from on high;" and, until this promised power should be given, they were not to begin their preaching, nor depart from Jerusalem.

This promise is repeated again and again. "When He the Spirit of Truth is come, $\mathrm{He}$ will guide you into all (the) truth ; for He shall not speak of Himself; but whatsoever $\mathrm{He}$ shall hear, that shall $\mathrm{He}$ speak; and He will show you things to come (or the coming things)." (John xvi. 13.)

"When the Comforter is come, whom I will send unto you from the Father, even the Spirit of Truth, which proceedeth from the Father, He shall testify of Me." (xv. 26.)

"When they shall lead you and deliver you up, take no thought beforehand what ye shall speak, neither do ye premeditate; but whatsoever shall be given you in that hour, that speak ye: for it is not ye that speak, but the Holy Ghost." (Mark xiii. 11.)

Our Lord could not affirm more distinctly the personality of the Holy Ghost, and that He employs prophetic men as $\mathrm{His}$ organ of speech.

"The Holy Ghost shall teach you in the same hour what ye ought to say." (Luke xii. 12.) 
And if what they "ought to say," then surely, and much more, what they ought to write.

But some have said, What our Lord promises here is promised not to the Apostles only but to all Christians: why should we ascribe to them any inspiration differing in kind from that general guidance and illumination which we believe all good Christians more or less possess?

That this notion will not satisfy the terms of Christ's promise is clear from the following passage :-

"The Holy Ghost whom the Father will send in My name, He shall teach you all things, and bring all things to your remembrance, whatsoever I have said unto you." (John xiv. 26.)

Here the promise is limited, by its very nature, to those who had been ear-witnesses of our Lord on earth, to the men then standing around Him.

We do not for one moment mean to deny to the Church of after ages the presence and enlightenment of the Blessed Comforter; our Collect for Whitsuntide forbids it; St. John, in his Epistle (1 John ii. 27), forbids it.

But that Christ meant us, in these after ages, to have the power of predicting future events, of being irresistibly eloquent without premeditation, or of remembering conversations to which we never listened, none will venture to affirm. 
Such then was Christ's promise.

2. Was it fulfilled?

Yes, within ten days of His ascension, we read that they were assembled together, waiting prayerfully for its fulfilment, when suddenly, with outward visible signs, the promised Spirit filled their hearts. There was suddenly a sound of rushing wind, and an appearance of flame over the head of each; and forthwith they began to pour forth certain ecstatic utterances. These were the outward sensible signs. In the sermon of St. Peter's that followed - so unlike to any previous utterance of the Apostle - we see the real purpose and power of the new gift. $\mathrm{He}$ speaks of it, moreover, as the promise of the Holy Ghost, which his risen Lord had received of the Father, and bestowed on them according to His word. (Acts ii. 33.)

And what was the immediate effect? "They were all filled with the Holy Ghost, and they spake the word of God with boldness." "With great power gave the Apostles witness of the resurrection of the Lord Jesus, and great grace was upon them all." (iv. 31, 33.)

But, 3. Do they in their writings claim for their words such Divine authority as the possession of such a gift ought to confer?

Clearly they do, again and again :-

"We speak," St. Paul wrote, " not in the words 
which man's wisdom teacheth, but which the Holy Ghost teacheth." (1 Cor. ii. 13.) "For this cause we thank God without ceasing, because when ye received the Word of God, which ye heard of us, ye received it not as the word of men, but, as it is in truth, the Word of God." (1 Thess. ii. 13.)

"He that despiseth, despiseth not man but God, who hath also given unto us His Holy Spirit." (1 Thess. iv. 8.)

"I certify you, brethreu, that the Gospel which was preached of me, is not after man; for I neither received it of man, neither was I taught it, but by the revelation of Jesus Christ." (Gal. i. 11, 12.)

"God hath revealed these things unto us by His Spirit; for the Spirit searcheth all things, yea, the deep things of God." (1 Cor. ii. 10.)

"Which things," St. Peter writes, "are now reported unto you by them that have preached the Gospel unto you with the Holy Ghost sent down from heaven." (1 Pet. i. 12.)

Thus clearly do the writers of the New Testament claim that Divine authority for their teaching (both oral and written) which Christ had no less distinctly promised them.

All this, if we may venture so to speak, was according to the plan of Christ. Christ could not publish His Gospel to the world, or found His kingdom, in the days of His humiliation. Not till the Re- 
deemer had died could the Redemption be announced; not till the King had ascended His throne could the kingdom be inaugurated.

Both the dissemination of the Gospel, and the building of the Church, were the functions of the Holy Ghost; and for these purposes the Holy Ghost needed the organ of human speech. Therefore "He spake by the Prophets."

But although it is very clear that the Prophets of the Christian Church are here principally intended, the Prophets of the Old Testament are of course included in the plirase. By them, in old time, from time to time, the Holy Ghost spake and made known the mind of God.

Of the inspiration of the writers of the Old Testament, our Lord and His Apostles leave us in no doubt. They are continually asserting it.

Speaking of the writers of the Old Testament, St. Peter says, "Holy men of God spake as they were moved by the Holy Ghost." (2 Pet. i. 21.) And St. Paul, "All Scripture is given by inspiration of God." (2 Tim. iii. 16.)

Both our Lord and His Apostles commonly refer to the words of the Old Testament as the words of the Holy Ghost.

"David himself said by the Holy Ghost." (Mark xii. 36 , and Acts i. 16.)

"Well spake the Holy Ghoșt by Esaias the Prophet unto our fathers." (Acts xxviii. 25.) 
"Wherefore, as the Holy Ghost saith, To-day if ye will hear His voice ...." (Heb. iii. 7.)

So the Old Testament Prophets themselves continually, "Thus saith the Lord," claiming thus to be the mouthpiece of the Holy Ghost. Very noteworthy is the challenge addressed to the false teachers, to say whether they could claim the gift of predicting future events, as the prophets of Jehovah could. (Isa. xliv. 7 ; xlv. 21.)

But we remark that under the Old Dispensation this outpouring of the Holy Ghost was neither continuous nor general. There were long intervals during which (we read) "there was no open vision" (1 Sam. iii. 1), and it was only on some chosen man here or there, that the gift of this inspiration descended.

Hence the contrast between the gift under the Old and New Dispensations.

Joel prophesied that " in the last days" (i.e., under the New Dispensation) saith God, "I will pour out my Spirit upon all flesh; and your sons and your daughters shall prophesy ... . and on My servants and My handmaidens I will pour out, in those days, of My Spirit; and they shall prophesy." (Joel ii. 28 ; Acts ii. 17.)

This accounts for the phrase of St. John in recording a similar prediction of our Lord's. "This spake $\mathrm{He}$ of the Spirit, which they that believe on Him 
should receive; for the Holy Ghost was not yet (given); because that Jesus was not yet glorified." (John vii. 39.)

"The Holy Ghost was not yet," - clearly meaning the promised outpouring foretold by Joel had not yet arrived. Compare Acts xix. 2.

We have then a twofold promise of the Holy Ghost under the New Dispensation :-

1. A general outpouring of the strengthening and enlightening grace of the Holy Spirit, who should make the heart of the Christian His Temple and dwelling-place.

2. The return after an interval of four hundred years or more of a time of "open vision," when there should be an order of Prophets once more upon the earth, as in the days of Samuel, as in the days of Elijah and Elisha, as in the days of Daniel.

Such a time of "open vision" were the forty or fifty years that followed the Ascension of our Lord. The Holy Ghost once more "spake by the Prophets."

One only question remains : Does the Holy Ghost no longer speak to man?

That He no longer speaks to man by the mouth of Prophets must be allowed.

It seems to be a proved historical fact that the Pentecostal gift of extraordinary inspiration, that is of Prophecy, ceased with the generation of men on whom the Apostles had laid their hands. 
How then since that date has the Holy Ghost been speaking within the Church?

First, $\mathrm{He}$ speaks to us through the Word written. Like the Jews after the closing of the Old Testament Canon, and the hushing of their last prophet, we have become a "people of a Book." As St. Paul said of his nation, so may it be said of us Christians: "What advantage then," have we? "Much every way: chiefly because that unito" us are "committed the oracles of God." (Rom. iii. 2.) In this way the Holy Ghost still speaks to us by the Prophets.

But, secondly, Our Lord's promises clearly embolden us to believe that in the united voice of the Church the Holy Ghost yet speaketh.

But we cannot enter upon this without anticipating the subject of the next chapter.

Enough, perhaps, has been said to set forth the Doctrine of the Personality and Divinity of the Holy Ghost, and how He reveals to man the mind of God. 


\section{CHAPTER V.}

THE CHURCH.

HAVING in the last chapter spoken of the Person 1 of the Holy Ghost, let us now proceed to consider His work.

In adopting this order we are following the guidance of our Catechism and Creeds. The Catechism puts it very shortly: "I believe, thirdly, in God the Holy Ghost, who sanctifieth me and all the elect people of God." But this work, which the Catechism thus sums up under the one word sanctification, the two Creeds develop into a fourfold work.

First, the organization of a Holy Catholic Church. And then, through this Church so organized, the realization of three great blessings, a Communion of Saints, a Remission of Sins, and a Resurrection to eternal Life.

We must in this chapter consider the Spirit's work of Church organization.

That this is emphatically the work of the Holy Spirit is plain from Scripture. It is evident that Christ never regarded it as a work to be accomplished during His own sojourn on this earth. His language 
was ever, " The kingdom of Hearen is at hand," not "The kingdom of Hearen has arrived."

It was needful that the King should be enthroned in glory before His kingdom could be established. Christ's work on earth was a work of suffering; for only through suffering could $\mathrm{He}$ enter into His glory. This, therefore, was the work to which on earth $\mathrm{He}$ straitened or confined Himself. ${ }^{1}$ The more glorious work He left to the Holy Spirit or Comforter, whom He promised to send. It was expedient, therefore, that $\mathrm{He}$ should go, in order that the Holy Spirit might come. "He shall glorify Me," $\mathrm{He}$ said. Christ had been with His people, the Holy Spirit (and through the Holy Spirit the Son also in His Divine Nature) should be in them. ${ }^{2}$ We must mark the force of this: Christ during His earthly sojourn had no Temple. The Holy Spirit should build himself a Temple, and this Temple was the Church.

Hence the Apostles were forbidden to commence their ministry until the Adrent of the Holy Spirit. That day of Pentecost was the birthday of the Church. On that day the foundations of the ererlasting Temple promised to Darid were laid. Jesus Christ was the chief Corner Stone, but the Holy Ghost was the builder.

1 "I hare a baptism to be baptized with: and how am I straitened until it be accomplished !" - Luke xii. 50 .

2 John xir. 17; x rii. 23. 
This, then, was His work, on the consideration of which we now enter.

\section{CONSTITUTION AND NOTES OF THE CHURCH.}

What is the Church? And how is it to be known?

We must turn to the teaching of Christ and His Apostles; and first, to that of Christ. Nearly half of our Lord's teaching was about the Church that was on the eve of being established on the earth. $\mathrm{He}$ spoke of it under the name which His hearers would most readily recognize. The prophecies of Daniel were very familiar to them. Therefore, as our Lord adopted Daniel's expression for the Messiah, "the Son of man," so for the Church also He adopted Daniel's phrase, "the Kingdom." "The God of Heaven shall set up a Kingdom." A Kingdom is said to be given to the Son of man. ${ }^{1}$ So the Baptist had declared that this Kingdom was at hand. Christ, too, came preaching the Kingdom. In the Sermon on the Mount $\mathrm{He}$ laid down the laws of this future Kingdom. Many of His parables were designed to teach people what it would be like. It was to be like the estate of an absent landlord, showing that Christ would not reign visibly over His Church. It was to be like the mustard seed, showing how it was to grow from a very small beginning. It was to be

1 Dan. ii. 44 ; vii. $13,14$. 
like a net taking good and bad fish, a field sown with good and bad seed, a marriage feast where some had not a wedding garment; - showing that in this world the members of the Church would be a mingled company of good and bad.

All this was to the multitude. To His Apostles Christ spoke of the future government of His Church; how there was to be one, and only one, mode of admission, namely, by Baptism (John iii. 5; Matt. xxviii. 19); how those who were baptized were to be bound together in communion with each other and with Christ by the Sacrament of the Lord's supper; how He meant to give to His Church sovereign authority to admit or reject members; how this authority was to be devolved on the Apostles in the first instance; how He in Heaven would confirm their decisions; how $\mathrm{He}$ would be with them wherever two or three were gathered together in His name; how the Holy Spirit should dwell in this Church as in His Temple, and guide them into all truth; how $\mathrm{He}$ would never withdraw His presence, even to the end of the world; how, though false teachers might be expected, yet the gates of Hell should never prevail against it.

Such was Christ's teaching about His future Church before His death. In the great Forty days that followed His resurrection we are told that He spake " of the things pertaining to the Kingdom of God," giving 
" commandments" about it to His Apostles. (Acts $\mathbf{i}$. 2, 3.) What these more particular instructions for the organization of the Church were we are not directly told. But indirectly we may learn what they were, by watching the manner in which the Apostles gave them effect.

Let us take some one famous Church, and observe how it was founded and organized.

We know more perhaps about the Church of Ephesus than any other; for not only have we in the Acts a full account of its foundation, but we have also a long pastoral address delivered to its Presbyters by St. Paul ; three of his Epistles specially addressed to Ephesus; ${ }^{1}$ and, finally, our Lord's Epistle to this Church in the Book of Revelation. Thus Holy Scripture gives us knowledge of the Ephesian Church during some forty years of its early history.

Let us turn to the account of its foundation in the nineteenth chapter of the Acts. We there read how St. Paul came to Ephesus, and there abode three years, disputing and persuading the things concerning the Kingdom of God, - using, we observe, our Lord's own phrase for the Church. Twelve disciples of John the Baptist he found there. He asked them whether they had received any of the gifts of the Holy Spirit? No, they had not heard of the great outpouring on

1 One, a circular letter, to the Ephesians among others; two to their. Bishop. 
the day of Pentecost. Then St. Paul instructed them more fully, and they received Christian baptism, and the gifts of the Holy Ghost. Such was St. Paul's first beginning at Ephesus. Two things we here observe. The Apostle points to the Holy Ghost as the only Power whereby a Chur'ch can be founded or held together ; and next, he requires Baptism as necessary to admission.

In the following chapter we have St. Paul's pastoral address to the Presbyters of this same Church four years after its foundation, when it had grown to considerable importance. From this address we learn that during St. Paul's residence among them the main subject of his teaching was still " the Kingdom." $\mathrm{He}$ speaks of having gone about among them preaching not only repentance and faith, but also " the Kingdom of God."

He had ordained all these Presbyters whom he was addressing. He calls them "overseers" (or Bishops) whom the Holy Ghost had set over the Church. Thus we have an ordained Ministry distinctly recognized, and their Ordination no less distinctly spoken of as an operation of the Holy Ghost.

In the third place we find St. Paul four or five years later addressing a circular Epistle to this same Church among others. And of this Epistle the chief purpose was to lift these Ephesian Christians into a consciousness of the grandeur of their vocation. The Church 
of which they were members was not merely a local institution; it was more; it was a living portion of that one Holy Catholic Church which was the Household of God, the Mystical Body of Christ, the Temple of the Holy Ghost.

Grounded in the predeterminate Counsels of the Father, redeemed by the Blood of the Son, sanctified by the indwelling Spirit, the Church could have but one Lord, one Faith, one Baptism. (Eph. iv. 5.) These were the notes whereby the true Church was to be known, whether at Ephesus or elsewhere :-

Allegiance to one Lord.

Confession of one common Creed.

Participation in the same Sacraments.

These are the three outward and visible marks whereby we are to recognize the genuine Church of Christ.

The date of this Epistle to the Ephesian and other Asiatic Churches of St. Paul's founding marks an epoch in the development of the doctrine of the Christian Church. Heretofore St. Paul had always spoken of the Churches in the plural number; and such, from. first to last, is the language of the Acts of the Apostles. It was not until his long-cherished wish to visit Rome was fulfilled, and he found himself looking out upon all these several Churches from this, the metropolis of the Roman Empire, that the glorious truth of the imperial unity of Christ's Kingdom 
dawned upon him, and became his habitual thought. At any rate, it finds no expression in his earlier Epistles. In them it is always "the Churches" of which he speaks. In the Ephesian Epistle it is "the Church."

And he notes carefully, as we have seen, the marks whereby membership in this One Church was to be verified.

Then he goes on to declare how Christ appointed a varied Ministry, Apostles at the head of all; then Prophets, who were to preach the Word ; then Evangelists or Missionaries; then Pastors, who were to have cures of souls; and, lastly, Teachers, who were to care for the young and uninstructed.

Thus were the Saints to be perfected, that is, to grow in holiness; thus was the Body of Christ to be compacted; thus was the Temple to be built up as a habitation wherein God's Spirit might dwell.

This organization of the Ministry of the Church is more fully prescribed in the two Epistles which St. Paul addressed to Timothy, who, in the Apostle's absence, presided over the Ephesian Church. In these Epistles he lays down very careful directions for Timothy's guidance in the selection and ordination of Presbyters and of Deacons.

They are to be men whose own homes are well ordered, who are bringing up their children well; sober, and temperate in their habits. Each is to serve 
as a Deacon first, and if approved, to be advanced to Priest's Orders. Timothy's own higher office as Vicar Apostolic, is to ordain ministers (iii. 1-13), to assign them their stipends (v. 17), to maintain discipline, to examine and (if need be) excommunicate offenders, to regulate the almsgiving and sisterhoods, or Deaconesses, ${ }^{1}$ of the Church.

From the Second Epistle to Timothy we see how anxious St. Paul was to preserve a succession of faithful ministers in the Cliurch. He had himself ordained Timothy, and he charges Timothy in turn to "commit to faithful men" the doctrine which he had received, that they, too, might transmit the doctrine unalloyed to others. And so it might be kept pure.

How necessary this was we learn partly from the mention in this same Epistle of false teachers who were creeping in; and still more from the Epistle which our Lord Himself, in the second chapter of the Revelation, charges St. John to deliver to one of Timothy's successors in the government of the Ephesian Church. There we learn that men were boasting that they had the Apostolic order who had it not, and were seducing the Ephesian Christians from their fidelity.

From this rapid review of the constitution of the Ephesian branch of the early Christian Church, we

1 It is now generally agreed that the word rendered "their wives " in 1 Tim. iii. 11, should be translated the "Deaconesses." 
may gather very clearly the definition of the Catholic Apostolic Church in which the Christian professes in his Creed that he believes. And it agrees with that given in our xixth Article :-

It is a divinely-instituted society, maintaining its continuity from age to age by unity of doctrine, and by the due administration of the Sacraments. We must add that to secure this unity of doctrine and due administration of the Sacraments, two things were plainly regarded by Christ and His Apostle as necessary ; namely, Discipline, and a succession of duly ordained Ministers.

No community of Christians, therefore, who can show that they fulfil the following conditions, can be refused recognition as a branch of the one Holy Catholic Church of Christ :-

1. The acknowledgment of the One Lord.

2. Acceptance of the Christian Creed.

3. The due administration of those two Sacraments which Christ Himself ordained.

4. And as security for the transmission of the Creed and Sacraments, Church Discipline, and a continuous Ministry.

The third and fourth of these notes of the Church may seem to need further explanation.

In respect of the third, it may be asked why did St. Paul in his formula - " One Lord, one Faith, one 
Baptism" (Eph. iv. 5) - mention one of the two Sacraments only? The answer is obvious; he was addressing individual Christians, and speaking of their notes of Church-membership. To have included the other Sacrament among these essential notes of Churchmembership would have excluded infants, and would have excluded also non-communicants. Holy Seripture teaches, and our Church declares, that every one who is duly baptized and continues to acknowledge the one Lord, and to profess the Christian Creed, is to be reckoned a member of the Church, although he be not a communicant.

That there should be adult non-communicants within the pale of the Church may be matter for regret and humiliation. But our Lord foretold this mingled character of His Church. Are we to refuse to recognize them? "Wilt Thou that we go and gather them up? But He said, Nay: lest while ye gather up the tares, ye root up also the wheat with them. Let both grow together."

St. Paul therefore mentions the one introductory Sacrament in his definition of individual Churchmembership. But we know from another passage that he included the other Sacrament in his definition of a Church Community.

Speaking of the "many" of the Church at Corinth, he says plainly, in 1 Cor. $x .16$, that it is the breaking of bread and partaking of the Cup which puts 
them into communion with Christ; it is the partaking of the one bread that makes them, being many, " one body," - of the Body of Christ.

Our church is therefore clearly in accord with St. Paul in mentioning the due administration of both Sacraments as a note of the Church.

Let this suffice in explanation of the third note. Let us proceed to the fourth.

Besides the Common Lord, the Common Faith, and the Common Sacraments, there must be a continuous Ministry and Discipline.

But our Church in her Articles seems to agree with Hooker in teaching that, although some ministerial regimen and some Discipline are essential to every branch of Christ's Church, yet that uniformity of regimen and Discipline is not necessary.

Therefore no prescribed form of Ministerial Polity or of Discipline is included in our Article's definition of the Church of Christ.

As in the days of the Apostles, so now, while, on the one hand, we believe in the one Holy Catholic Church, so we believe, on the other hand, that this one Body is made up of independent National or Particular Churches; united in respect of the three great points above mentioned (the same Lord, the same Faith, the same Sacraments) ; independent one of another in respect of government and discipline.

But while our Church jealously maintains this in- 
dependence of particular Churches in respect of Polity, she clearly asserts her own belief that the threefold Orders of Bishops, Priests, and Deacons, are of Apostolic origin and authority. ${ }^{1}$

How may this be shown? Very simply:-From the Pastoral Epistles it clearly appears that Timothy and Titus held a grade of ministry superior to and distinct from that of the Presbyters and Deacons whom they are commissioned to ordain; and from Rev. ii. 1 it seems that they had successors in this higher office. Whether this highest grade received then, or a generation later, the distinctive name of Bishops, is unimportant; and whether now they be called Bishops, or Chief-Pastors, or Chief-Presbyters, is unimportant. What we do hold to be important, as a safeguard provided (as we believe) by the Apostles for the continuance of the ministerial succession, is that there should be a higher Order, above that of Priests and Deacons, responsible for all ordinations.

We may therefore venture to interpret the mind of our Church in respect of non-episcopal Churches, thus :

As to those that have abandoned episcopacy, but have retained the presbyteral succession, all that we affirm is that they have lost a very important safeguard, but our definitions do not exclude them from the Catholic Church.

1 See the Preface to the Ordinal. 
As to those who have abandoned, not only episcopacy, but the presbyteral succession also, we say that they are new societies, Christian it may be, but certainly not branches of the old historic Church of the Apostles.

But this leads us on to a further question -

IS THE CHURCH OF CHRIST VISIBLE OR INVISIBLE?

It may be said, "If the Christian Church be an external visible fact in the world's history, why make it an article of faith? It is the unseen that requires to be believed by an effort of faith, not what is visible."

Some answer: "The Church spoken of in the Apostles' Creed is, not the outward visible society so called, but the invisible society of those who are truly Christian at heart, known only to God."

This distinction between a visible and invisible Church was a favorite notion of the English Reformers. But it is a modern notion; and is not to be found in the New Testament. There the Church is always spoken of as a visible society of professing Christians, some more some less sincere, some more some less holy in their lives; intended to be thus mingled until the Day of Judgment, when God, who knows the heart, will separate them. Such is the teaching of our Lord's Parables of the Net and of the Tares; and such is the teaching of the Apostles who 
in their Epistles address all as members of the Church and as "called to be saints," though many require to be sternly reproved for their unholy lives.

But if this be so, and if the Holy Catholic Church mentioned in the Creed be a visible society, whose establishment after our Lord's Ascension is a plain historical fact, why make it an article of faith?

The answer is a very simple one: It is unlike all other merely human societies ; it is a divine society, instinct with divine power such as no other society in the world possesses, and this, its supernatural character, being invisible, is an article of faith.

What then is this divine power possessed by the Church?

It is the power of the Holy Ghost dwelling in the Church and working through the Church's organization for the sanctification of her members. And by this is meant - not the direct action of the Holy Ghost on the heart of the individual Christian - that might be carried on if there were no Church - but the indirect action of the Holy Ghost on Christians through the Church's organization.

And how is this indirect action exercised? In other words, what are the means of grace offered by the Church to all her members?

1. The ministry of the Word.

2. The ministry of the Sacraments.

3. The ministry of Discipline. 
Of this threefold ministry some further explanations may be needed.

THE MINISTRY OF THE WORD AND SACRAMENTS.

And first, the ministry of the Word. Of God's Word written we have already said enough.

On that first generation of Christians, and especially on those who were Apostles or of Apostolic rank, was devolved a responsibility which has rested on no succeeding generation of Christians. That first age had to commit to writing, and so fix for all time, the Revelation which had been made to the world by Christ. We have seen in the last chapter how they were specially qualified for their task by an extraordinary gift of Inspiration.

We pass on, therefore, to the consideration of God's Word spoken, to the ordinance of preaching as a means of grace in subsequent ages. Is this equally inspired? No, certainly not. Just so far as the preacher is a holy and prayerful man will he have the assistance of the Holy Spirit in his preaching, and no further. The Pentecostal gift of extraordinary inspiration ceased with that first age.

What security, then, have we that the word spoken by the Church's ministers shall still be God's Word to us?

Absolute security we have none.

But our Lord's Apostles made such provision as 
they could, to insure the preaching of true doctrine in all subsequent ages of the Church.

How was this provided for? As the continuance of the Sacraments was provided for - by the appointment of an ordained ministry. No attentive reader of the New Testament can fail to see how carefully the ministry of the Word and Sacraments was hedged about.

First by our Lord : He did not commission all His disciples to be Ministers of the Gospel, but only chosen men whom he named Apostles. ${ }^{1}$ They were to preach, and to baptize, and to break bread in remembrance of Him.

After His resurrection $\mathrm{He}$ gave them a yet more solemn commission - "As my Father hath sent me, even so send I you." And that this commission was not limited to the Apostles, but meant to extend to their successors also, He made plain by adding, "Lo, I am with you, even to the end of the world."

Most careful, therefore, were the Apostles to ordain elders in every city by the laying on of hands, who should continne this Ministry in their absence, and after their death.

In the New Dispensation as in the Old no man can undertake the priesthood except " he be called of God," as the Epistle to the Hebrews witnesses. (v. 4.)

1 Whether the Seventy, subsequently appointed, were a permanent order or no, we cannot certainly decide. 
Accordingly St. Paul asks, "How shall they preach except they be sent?" (Rom. x. 15), and forbids the notion that all are equally entitled to preach, asking, "Are all apostles? are all prophets? are all teachers?" (1 Cor. xii. 29.)

So careful was he to provide for the ordination of qualified men as ministers, that when he could not visit a Church himself for this purpose, we find him sending a Vicar-Apostolic to act for him, as Timothy to Ephesus, and Titus to Crete. From the instructions which he gave them, we learn that their chief function was their ordination of deacons and elders. They were to select, prove, examine, and by laying on of hands commission these deacons and presbyters.

And again and again he charges them to deliver to these younger ministers the same sound form of words, the same sound doctrine which they (Timothy and Titus) had received from the Apostles at their own ordination.

This deposit of doctrine they were to transmit to the younger generation.

"Hold fast the form of sound words which thou hast heard of me ; - that good thing which was committed unto thee, keep by the Holy Ghost which dwelleth in us. And the things which thou hast heard of me among many witnesses, the same commit thou to faithful men, who shall be able to teach others also." (2 Tim. i. 13, 14; ii. 2.) 
This extreme care of the Apostles to provide a constant succession of duly ordained ministers in the Church is to be noted. The early Fathers in arguing with heretics appeal again and again to the continuity for the Christian ministry, as a very important security for the transmission of true doctrine. ${ }^{1}$

There are always some who chafe under these wise restrictions who would relax all rules, admit all to be ministers, do away with all subscription to formularies. Not so Christ's Apostles. They would allow none who were not duly approved and commissioned to take upon them this ministry.

To the inspired foresight we owe it that this sacred torch of divine truth and these sacraments of grace have been handed down to our later days.

We have now spoken of the Christian ministry with special reference to the dispensation of the Word and Sacraments. But this involves them in another duty, the duty of maintaining Church discipline. To this we must now pass.

1 See Irenæus, iii. 2, 3, 4. If you wish (he argues) to ascertain the doctrine of the Apostles, apply to the Church of the Apostles; in the succession of bishops tracing their descent from the primitive age and appointed by the Apostles themselves, you have a guarantee for the transmission of the pure faith, which no isolated, upstart, self-constituted teachers can furnish. See also Hegesippus in Eus. H. E. iv. 22; and Tertullian de Prcescr. 32. 
CHURCH. DISCIPLINE - THE POWER OF THE KEXS.

In every organic society sovereign power must rule over the members of the society, and must rest somewhere: - the power of admitting, the power of censuring, the power of rejecting, the power of readmitting those who have been excluded, this power must rest somewhere, either in the society collectively, or in some governing body. This is essential to all societies. Most of all essential is it in the case of a society which claims to bestow on all its members the very highest of all privileges the covenanted favor of God.

The phrase used in Scripture for this inestimable privilege which full Church-membership carries with it, is remission of sins.

To be admitted into this society is, in Scripture language, to be " baptized into the remission of sins." St. Peter's invitation on the day of Pentecost was, "Be baptized for (or rather into) remission of sins." (Acts ii. 38.)

Hence the phrase in our Creed :-

"I acknowledge one baptism for (or rather into, as an admission into) the remission of sins."

As the one sacrament admits us into it, so the other sacrament is said by our Lord Himself to preserve us therein. In instituting the Holy Communion His words were, "Drink ye all of this, for this 
cup is the new covenant in My blood for the remission of sins."

"Remission of sins" therefore both in the New Testament and in the Creed means a present state of pardon or favor, or acceptance; it is the "state of salvation" spoken of in the Church Catechism.

As Church-membership, then, carries with it so inestimable a benefit, clearly the responsibility of dispensing it is proportionably great. On whom does it rest? Christ foresaw the need of providing for the exercise of this responsibility. He appears to invest His Church at large with this sovereign power over its members, and also He seems to provide that the Church should devolve it upon her ministers.

Three passages occur to us at once where Christ seems to speak of this matter.

The first is to St. Peter in Matt. xvi. St. Peter had just confessed his full belief that Jesus was the Son of God. A holy joy seemed to fill our Lord's heart that one of His Apostles had now, for the first time apparently, realized the full truth of His Divine nature; He turns to him, and there and then gives him the keys of His Kingdom: "Whatsoever thou shalt bind on earth shall be bound in heaven: whatsoever thou shalt loose on earth shall be loosed in. heaven." A phrase most familiar to a Hebrew; "binding and loosing" being the common expression among the Jews for the exercise of authority. 
Clearly our Lord meant to clothe St. Peter with authority to be a ruler in His Church. By " binding and loosing" Christ clearly meant admitting into or rejecting from Church communion.

But was St. Peter alone to have this authority? No. We turn to the next passage: it is in the eighteenth chapter. Christ is there speaking of offending members of the Church. For Christ saw plainly that in His new society there would be offences. How are they to be dealt with?

Gently, at first by expostulation. "If thy brother shall trespass against thee, go and tell him his fault between thee and him alone," - privately, Christian expostulating with Christian. This may suffice: let it be first tried. "If he shall hear thee, thou hast gained thy brother. But if he will not hear thee, then take with thee one or two more "witnesses, as it were, to strengthen the expostulation. And if the offending brother still neglects to listen, what then? "Tell it unto the Church." The case must now be brought before the society publicly. But how if he still refuse obedience? "If he neglect to hear the Church, let him be unto thee as a heathen and a publican" - the ordinary expression for being put out of the synagogue. "Let him be put out of the Church's communion," excommunicated.

No society could exist, as a society, without this power of expelling obstinate offenders. And Christ 
adds: "Verily I say unto you" (unto you, not unto thee, for Christ is speaking of the whole society now), "Whatsoever ye shall bind on earth shall be bound in heaven : and whatsoever ye shall loose on earth shall be loosed in heaven." Christ in heaven will confirm these sentences of His Church. "For where two or three are gathered together in My name, there am I in the midst of them." (Matt. xviii. 18-20.)

We see that the same authority which Christ before had seemed to give to St. Peter singly, He now gives to the Church at large, as a self-governing society. As we said, no human society could exist, as a society, without such sovereign authority over its individual members.

Thus, from these two passages, we learn that Christ gave, on one occasion to St. Peter, on another occasion to the Church at large, the power of " binding and loosing;" and that by this phrase He meant the power of excommunication and the power of admission.

Now, may these two passages (Matt. xvi. 19, xviii. 18) be taken to explain the third and most important passage in St. John (xx. 23)? -

"Whose soever sins ye remit, they are remitted unto them ; and whose soever sins ye retain, they are retained."

We observe that whereas in those two passages the phrase was " binding and loosing," the phrase here is " remitting sin and retaining sin." 
At first sight this latter phrase seems to convey a more awful meaning. And yet the wisest of our English divines ${ }^{1}$ have explained the one phrase by the other. How? Not by lowering the latter, but by raising the former.

Do we sufficiently realize to ourselves all that is contained in the privilege of being in communion with the Church? If Christ's Church be in truth His Body; if to be in communion with the Church is to be in communion with Christ; and if to be in communion with Christ is to be one of an accepted, forgiven people, - then, to be cast out of that communion would seem to mean the forfeiting of that forgiveness; and to be admitted into that communion would seem to mean being made a sharer in that forgiveness. And thus we may explain the latter phrase - " remitting and retaining sin" - by that former phrase, " binding and loosing Church-membership."

Without for one moment lowering the phrase of St. John, we have thus obtained a most important qualification of it. We have come to see, by the help of that other phrase of St. Matthew, that the forgiveness or remission of sin spoken of in this passage of St. John is not direct, but indirect. And this is most important.

Directly none but God can forgive sin. But if God

1 See for instance Hammond on John xx. 23, and Bishop Harold Browne on Art. xxxiii. 
grants pardon to a certain community, and certain persons have the power of including in, or excluding from, that community, then, indirectly, those persons are intrusted with the dispensing of God's pardon.

But is not this (some may say) a distinction without a difference? Is it not virtually the same thing as giving them the power of forgiving sin? No. The illustration of an amnesty will make the difference clear.

A king grants an amnesty to all the inhabitants of a country who will, before a certain day, assemble themselves within the walls of his royal eity. And to his officers he gives the keys of the eity gates, to admit or to exelude. What happens? Some seek admission, and are admitted. Some are refused. Some decline to eome. Clearly those inside are most safe. Clearly those outside run a great risk. That is all the officers can say. The prerogative of merey still rests with the king, and the king only. Those inside the city, though now amnestied, may, by their subsequent conduct, forfeit the amnesty. And those ontside, though not included in the present amuesty, may eventually be pardoned by the king's free merey.

So it is with the power of the keys of the new Jerusalem. Christ's Chureh, Christ's ministers, admit and reject from Cliureh eommunion. And they ery alond, and say, Those inside are most safe, and those outside run a great risk. But they never confuse 
this power with the power of actually forgiving sin. The forgiveness of sin belongs to God, and God only.

Now, let us proceed to inquire whether this distinction between the power of the keys, and the power of forgiveness of sin, is borne out by the Apostles' own interpretation of their commission, as shown by their subsequent exercise of it.

Two conspicuous examples occur at once, - the case of Simon Magus, and the case of the incestuous Christian at Corinth. In the first case, a man had been admitted to baptism whom the Apostles afterwards discovered to be unworthy of Church communion. Without any hesitation, remembering their commission, they excommunicate him. And in going so they are confident God will approve and ratify this their judgment. But we must mark well how carefully they distinguish between this their apostolic judgment and God's final judgment. St. Peter, while he excommunicates, adds the words, "Pray God, if perhaps the thought of thy heart may be forgiven thee." (Acts viii. 22.) Now look at the other case at Corinth. Again a baptized Christian falls into grievous sin. The Apostle, without any hesitation, commands the Corinthian Church to assemble in full congregation, and excommunicate the offender. But he adds these words after the sentence: "That his spirit may be saved in the day of the Lord Jesus." (1 Cor. v. 5.) 
Thus careful were the Apostles to distinguish between their prerogative of the keys and God's prerogative of forgiveness. As was before remarked, never once do we read of their saying, as Christ said, "Thy sins be forgiven thee." Clearly they did not understand our Lord's words, on that evening of Easter Day, to extend to them the Divine prerogative of forgiving sin against God. Clearly they understood the phrase "remitting and retaining" in the same sense as that other phrase in Matt. xvi. 18, "binding and loosing;" that, is, rejecting from, or admitting into, Church communion.

And now, in conclusion: Is this the sense in which the Chureh now applies Christ's words in the Ordination of Priests? Our soundest English divines (Hooker and Barrow, for instance) say that it is. And observe the immediate context: "Whose sins thou dost forgive, they are forgiven; and whose sins thou dost retain, they are retained. And be thou a faithful dispenser of the Word of God, and of His Holy Sacraments." May we not take these latter. words as intended to be an explanation - the very explanation we have been suggesting - of those former words? They are to remit sin by admitting to the ministry of the Word and Sacraments. They are to retain sin by excluding from the ministry of the Word and Sacraments.

One further proof may be given that this is the 
mind of the Church. Three examples of Absolution occur in the Prayer-book. We need not speak of the first, that in the Morning and Evening Prayer, for it is declaratory ; nor need we speak of that in the Holy Communion, for it is a prayer.

But let us turn to that in the Visitation of the Sick. There, if anywhere, the minister of Christ is making full use of that solemn commission intrusted to him at ordination; for listen to the words: "By Christ's authority committed unto me, I absolve thee from all thy sins."

At first sight it may seem to us, and to many I know it does seem, that the priest is here assuming to himself God's prerogative of forgiving sin. But is it so ? Do the priest's words mean that the sick man's account with God is thereby closed? Clearly not, for listen to what follows: Directly after uttering these words, the same priest kneels down, and represents the sick man as still " most earnestly desiring God's pardon and forgiveness."

What, then, did his words, "I absolve thee," mean? That same Collect teaches us, for it continues: "Preserve and continue this sick member in the unity of the Church." Observe, it is not, Restore him to the unity of the church; but, "Preserve and continue" him in the unity of the Church, to which, by my absolution, I have just restored him. It is his account with the Church — not his account with God 
- that the Prayer-book intends to be closed by that absolution.

For thus it is: The sick man is troubled in conscience; he has done things whereby he fears he may have forfeited communion with the Church, and whereby he knows he has displeased God. $\mathrm{He}$ is penitent. What, then, does the Church instruct her minister to do? From the first fear, he absolves him. From the second fear, he prays God to release him. Thus carefully does our Prayer-book make plain to us the meaning of this her most solemn absolution.

Oh that we valued more, as Christ intended us to value, this privilege of being in full communion with that holy Church which God has thus taken into covenant with Himself for Christ's sake! 


\section{CHAPTER VI.}

\section{THE SACRAMENTS.}

UR endeavor, in this chapter, will be to make plain to ourselves the Church's doctrine of the Sacraments.

We cannot have a better definition of a Sacrament than that given in our Catechism; it is as old, in substance, as St. Augustine : ${ }^{1}$ -

A Sacrament is "an outward and visible sign of an inward and spiritual grace given unto us, ordained by Christ Himself, as a means whereby we receive the same, and a pledge to assure us thereof."

Then the Catechism proceeds to insist especially on there being two distinct parts in a Sacrament.

"How many parts are there in a Sacrament?"

"Two; the outward visible sign, and the inward spiritual grace."

To suppose that these two things coalesce into one thing would (in the language of our Articles) "overthrow the nature of a Sacrament."

The two must be kept clearly and distinctly apart

1 See his 272d Sermon, ad infantes de Sacramento, and his 54th Epistle, ad Januarium. 
in the mind's eye, or we shall surely fall into confusion.

Still more needful is it to define to ourselves what we mean by a sign, and what we mean by a grace, in this passage.

Three fourths of the controversies which divide the Church arise from the bad habit of not defining the terms we use.

Let us begin, then, by defining the word sign, as it is used in this passage.

"A sign is a thing which, besides the impression it makes on the senses, of itself suggests the thought of something else to the mind." 1

The Latin word was often used for a seal; hence "to sign" means, in legal language, to ratify a thing either by setting one's seal to it, or by subscribing one's name; "signature" meaning properly either the one or the other. The words that accompany such legal signature are usually, "I sign, seal, and deliver this as my act and deed." A deed of sale, or a deed of gift, when so signed, becomes a legal instrument whereby property is conveyed from one party to the other. Many other signs were used by the ancients in ratifying covenants.

As in our Marriage Service, a ring is used, so, among the Romans, a few grains of corn were deliv-

1 "Signum est res, prxter speciem quam ingerit sensibus, aliud aliquid ex se faciens in cogitationem venire." $-\mathrm{S}$. Aug. De Doct. Christ. ii. i. 
ered by one party to the other. Among the Hebrews salt was handed over and eaten $;^{1}$ or a stone was set up; ${ }^{2}$ or a sandal was loosed, and passed from one to the other $;^{3}$ or they pledged one another in a solemn meal ${ }^{4}$ or, in more sacred covenants, an animal was sacrificed, and divided into two halves, between which the contracting parties were to pass. ${ }^{5}$ But, whatever the sign might be, a set form of words was always used, declaring what was covenated or conveyed; and (as St. Augustine remarks ${ }^{6}$ ) the sign was often called by the name of the thing signified.

When David poured forth the water of Bethlehem as a solemn libation to God, he said, "Is not this the blood of the men who went in jeopardy of their lives?" As often as the Israelites renewed their Paschal covenant they killed and ate a lamb, saying, "This is the Lord's Passover;" meaning that it was a sign announcing or showing forth to them and to their children that original Passover in Egypt whereby they had been redeemed.

Now that the word sign, in our definition of a Sacrament, is used with a special reference to this sense of the word, is plain from many considerations.

The language of our Articles agrees best with this notion. Sacraments are there said to be "certain

1 Lev. ii. 13; 2 Chron. xiii. 5.

2 Gen. xxxi. 45.

3 Ruth iv. 7 ; Ps. 1x. 8.

4 Gen. xxxi. 54 ; Ex. xxiv. 11.

5 Gen. xv. 10, 17.

6 Quost. in Levit. Ivi. 
sure witnesses, and effectual signs of grace;" and, again, the sign is described as "a sign or ceremony ordained of God." Still more plainly, in speaking of the Sacrament of Baptism, the sign is called an " $i n$ strument" whereby certain promises "are visibly signed and sealed."

St. Bernard, in a passage very often quoted, ${ }^{1}$ compares the Sacraments with our instruments of " $i n$ vestiture" (investiture into lands, honors, dignities), - which are significant and emblematical of what they belong to, and are, at the same time, means of conveyance, instancing a book, a ring, a crosier. And Bonaventura likens the outward sign to the signmanual of a king, which conveys a gift.

The divines of the sixteenth and seventeenth centuries repeat the idea continually. Hooker speaks of the Eucharist as being, to Christians, an instrument whereby the Lord Jesus "gives them in hand an actual possession of saving grace." The explanation is given still more expressly by Wake, Ussher, Brevint, Tillotson, and Waterland.

It need hardly be said that this idea of a Sacrament is suggested again and again in Holy Scripture. In several passages ${ }^{2}$ Baptism is likened to a seal; and, obviously, because it is the outward and visible sign, seal, or signature, whereby a Divine Covenant is ratified.

1 De Cxnâ Domini, Serm. i. p. 145, quoted by Waterland.

22 Cor. i. 22 ; Eph. i. 13 ; iv. 30. 
Again, in the case of the other Sacrament, our Lord, in His institution, used the word Covenant (or Testament) most emphatically: "This is the new Covenant in My blood;" having clearly in His mind the very similar words which Moses used in ratifying the Old Covenant, saying, "This is the blood of the Testament (or Covenant) which God hath enjoined unto you." 1

Now if we think of this meaning of the word "sign" in reading our Church's definition of a Sacrament, we shall at once understand the very important words that follow:-

This sign (the Catechism proceeds to say) must be one ordained by Christ Himself, "as a means whereby we receive," the inward spiritual grace, "and a pledge to assure us thereof."

The outward visible sign as really and truly conveys to us the inward spiritual grace, as the parchment deed, duly signed, sealed, and delivered, conveys property to the purchaser or heir.

Our Church teaches us distinctly that the one part of the Sacrament is a means of our receiving the other. Unless we will receive the outward visible sign which Christ has ordained, we have no right to expect the inward and invisible grace which $\mathrm{He}$ has promised.

1 Heb. ix. 20, where the reference to our Lord's words of institution seems to be clear. 
But here a further explanation, by way of caution, may be needed.

If there be one thing more clearly revealed than another, it is this: That in all God's gifts to man the Holy Spirit is the agent of the gift. St. Paul, after speaking of several divine gifts or graces, adds, "All these worketh that one and the self-same Spirit." 1 Our Lord declares that it was by the Holy Spirit that $\mathrm{He}$ worked His miracles, calling Him "the finger of God." 2 "He shall receive of mine (He said on another occasion), and shall show it unto you." 3 So, in the case of the Sacraments, the agent is the Holy Spirit. And inasmuch as this agent is a living Person, absolutely free (as Scripture reminds us $^{4}$ ) to come and go where and when $\mathrm{He}$ listeth, $\mathrm{He}$ cannot need any human or material means for the conveyance of God's gifts to man. 'This is most true. But it is equally true that He may will to employ such means as a rule. Thus the Israelites were cured of the serpent's bite by means of the Brazen Serpent; Naaman was healed of his leprosy by means of the waters of Jordan; the blind man, in the ninth chapter of St. John, had his sight restored, by means of the pool of Siloam. And yet, of all these intervening things, those words of the Wisdom of Solomon ${ }^{5}$ are

11 Cor. xii. 11.

3 John xvi. 14.

6 Wisd. xvi. 7 .
2 Luke xi. 20.

4 John iii. 8. 
true: "He that turned himself towards it was not saved by the thing he saw, but by Thee that art the Saviour of all!"

Therefore, to sum up this part about the outward visible sign in a Sacrament, - our Church teaches us, and Holy Scripture teaches us, that Christ has chosen to connect the grace of either Sacrament with an outward and visible sign as a "means conditional " " not a physical but a moral instrument" 1 — of our receiving the grace. We do not say that He could not, nay we allow that $\mathrm{He}$ might, impart the grace without the ordained sign; but we do say that we have no security or promise that $\mathrm{He}$ will do so; whereas we have a distinct promise and security that if we faithfully do the outward thing, He will assuredly impart the inward.

We must now pass on to the consideration of the other part of a Sacrament, the inward spiritual grace; and first we must define as carefully as we can the meaning of this word grace.

The English word "grace" has come to stand for two quite distinct Greek words. There is one Greek word ( $\chi$ áp $\iota s$ ) occurring more than a hundred times in the New Testament - meaning "God's favor." And our translators render this by the word "grace."

1 These phrases are Hooker's (E. P. v. lvii. 3, 4). 
There is another kindred Greek word ( $\chi u ́ p \iota \sigma \mu a)$ occurring very frequently (especially in the First Epistle to the Corinthians), meaning a gift which God's favor bestows on man. And this our translators very wisely render by the word "gift" - speaking of the "gifts of the Spirit," and "spiritual gifts."

But unfortunately St. Jerome was not so careful in translating the First Epistle to the Corinthians; and in the Vulgate version of that Epistle one and the same word, "gratia," is used both for the Greek word meaning God's favor, and for the Greek word meaning a divine gift.

From their great familiarity with the Vulgate, nearly all the theological writers of the Western Church thus became accustomed to use the word "gratia," in both senses; and the double use of the word grace may be traced all through our Prayerbook.

In the following passages the word is clearly used (as in our translation of the Bible) for Grod's favor or mercy or goodness.

"The throne of grace," $i . e .$, the throne from which we look for favor.

"The grace" (or favor) "of our Lord Jesus Christ and the love of God."

"Thy bountiful grace and merey."

"Thy children by adoption and grace."

No less clearly in these other passages the word 
stands for some gift or gifts which God's favor bestows : -

"Means of grace" (in the general Thanksgiving).

"Replenish her with the grace of Thy Holy Spirit" (the gift of Thy Holy Spirit). "Enrich them with Thy heavenly grace" (gifts which, like the Pentecostal gift, come down from heaven).

"Pour down upon us the abundance of Thy grace;" "pour Thy grace into our hearts" - in these passages the word clearly stands for the gifts of the Holy Spirit.

"Give grace to all bishops and curates," - clearly meaning "the many" excellent gifts" spoken of elsewhere.

Now in which of these two senses is the word used in these questions and answers in the Catechism?

Clearly in the latter. The inward and spiritual grace must be something bestowed, a charisma, a gift from God to man.

What the particular gift, or charisma, in any particular case may be, is quite another matter, needing further definition. Most commonly in the Prayerbook, the grace or gift we ask for is the grace or gift of the Holy Spirit. But the inward and spiritual grace bestowed in a sacrament is not the Holy Spirit; and clearly it needs further definition. Moreover, the gift or grace in one Sacrament is not the same as the gift or grace bestowed in the other Sacrament. 
This requires to be distinctly understood; because some in modern times speak or write about "Sacramental grace," as if it were a distinct something needing no further definition.

If we wish to avoid such confusion of thought, we should not speak of "sacramental grace," but rather (as the Catechism does) of " $a$ sacramental grace," — "an inward and spiritual grace." And it would tend still further, perhaps, to clearness of thought, if we used the word which more properly translates charisma, namely, "gift." Then every one would see at once that he was responsible for defining the gift, - the word "gift" in itself being indefinite.

We must, in the second place, therefore, proceed to define what the inward and spiritual gift is. Is it the same or is it different, in the two Sacraments?

According to the clear teaching of our Church in her Catechism it is different:- one distinct gift is bestowed in Baptism, and another distinct gift is bestowed in the Lord's Supper.

This will plainly appear in a separate discussion of the two Sacraments, to which we will now proceed.

\section{BAPTISM.}

What is the inward and spiritual gift in Baptism?

In one word it is Regeneration.

The answer in the Catechism resolves this single word into a twofold meaning, - 
"A death unto sin and a new birth unto righteousness."

What is the death unto sin? And why is it here spoken of as a gift of God, rather than our own act?

What.has been said (in a preceding chapter) of Christ's Atonement explains this. Christ's death was a death unto sin available for all mankind. ${ }^{1}$ It only remains that it be applied to us individually. And it is so applied in Baptism. All who are baptized in Christ are baptized into His death ${ }^{2}$ - the benefit of His death unto sin is made theirs. Thus we see how it is a gift or grace of God.

And what is the "new birth unto righteousness?" It is that gracious act of God whereby for Christ's sake $\mathrm{He}$ adopts us as His children, translates us into the kingdom of His dear Son, and so brings us under the sanctifying influences of His Holy Spirit, which, as consciousness opens, counteract the tendency to $\sin$ within us.

It is important to understand that this regeneration or new birth is as purely a grace or gift of God as natural birth. Therefore an unconscious infant is as capable of it as an adult.

Thus we see that the grace of Baptism is twofold, corresponding to the two parts of the theological idea of Original Sin.

For as in Original Sin there is to be considered 1 Rom. vi. 10. 2 vi. 3. 
(1) the wrong relation to God which we inherit, and which places us ipso facto under His displeasure; and (2) the corrupt tendency which we inherit also;

So in Baptism -

There is (1) a "death unto sin," which is an application to us of Christ's atonement, and consequently of Justification; for we are thereby brought into a right relation to God: ${ }^{1}$

And there is (2) "a new birth unto righteonsness," which is the commencement of a life under the influence of the Holy Spirit, - in other words the commencement of Sanctification.

The Justification is complete, though liable to be forfeited.

The Sanctification is inchoate only, for the hereditary tendency to sin remains in us, and will have to be gradually overcome.

But it may be asked, If a mere infant be capable of regeneration, and if regeneration be thus defined to include justification, what becomes of the doctrine of justification by faith?

The Church answers that when we speak of this gift of regeneration and justification on God's part requiring faith and repentance on our part, we mean that God requires as a condition of His gift that we shall lind ourselves (if adults), or be bound by others

1 It was shown in Chapter III. that restoration to a right relation to God is the best definition of justification. 
(if infants) to repent and believe. We cannot have the gift of regeneration without this accompanying obligation. For Baptism is a covenant.

Furthermore, by failing to fulfil this obligation we may forfeit the grace of Baptism. The character of Baptism (in theological language) we cannot lose, but the grace of Baptism we may lose.

We have been pardoned the inherited guilt, but we may contract fresh guilt; we have been placed in a health-giving atmosphere of grace, but we may refuse to breathe it.

Still, though the grace be in abeyance, the character of Baptism remains.

Baptism need not.be, and may not be, repeated.

Some may say, "Regeneration thus defined seems to mean admission into the Church merely."

We answer, Yes; with two provisos we accept the phrase :

(1.) It must be remembered that the admission is an act, not of man only, but of God also. The child's relation to God is altered.

(2.) It must be remembered that the Church is no mere human society, but the Temple of the Holy Ghost; so that one lifted into that Temple begins from that day forward to inhale a new element of spiritual life.

Regeneration - the grace or gift of Baptism - is now perhaps sufficiently defined. It is the result of 
two concurrent agencies. The Holy Ghost is the agent of the inward grace; man is the agent of the outward sign or seal, which is water, applied in the name of the Father, and of the Son, and of the Holy Ghost.

Both agencies are needed according to our Lord's doctrine : -

Nicodemus wished to know how a man could enter His kingdom ; - By being born again, Christ said.

And how born again? "Born of water and of the Spirit," was the reply.

Nicodemus, afraid of losing caste if he professed Christianity openly, wished to have the inward and spiritual grace without the outward and visible sign. But Christ insisted upon it - the water, as well as the Spirit, was needful to the new birth.

And so when charging His Apostles to make disciples by baptizing, He added, "He that believeth and is baptized shall be saved."

If ever the outward sign might have been dispensed with, it would have been in the case of Cornelius, on whom the Holy Ghost had already descended; or in the case of Saul, who had been converted by the Lord Himself.

But no! Cornelius must now be baptized, was St. Peter's first thought.

"Why tarriest thou? Arise, and be baptized, and wash away thy sins:" - were Ananias' words to Saul. 
In both these cases, by an extraordinary interposition, the inward and spiritual gift or grace had been already bestowed; but in both the Divine Lawgiver willed notwithstanding that the visible deed of conveyance should be duly executed.

In ordinary cases we have no right whatever to expect the gift or grace of pardon and regeneration until the outward and visible sign, ordained by Christ Himself, has been faithfully performed. We must "acknowledge one Baptism for the remission of sins." Such is our Church's clear and simple doctrine of Baptism.

\section{THE LORD'S SUPPER.}

We must now proceed to consider the other Sacrament, the Lord's Supper.

Here also, according to the Augustinian definition 1 of a sacrament, adopted in our Catechism, there must be an outward visible part and an inward invisible part. It will conduce to clearness if we begin with the latter :-

\section{The Inward Gift.}

"What is the inward part or thing signified?" "The Body and Blood of Christ which are verily and indeed taken and received by the faithful in the Lord's Supper.

1 "Sacramenta ideo dicuntur, quia in eis aliud videtur, aliud intelligitur." Serm. 272. - See also De Cat. Rud. xxvi. 
Thus clearly and distinctly and confidently does our Church Catechism assert that what is given us in the Holy Communion is the Body and Blood of Christ. And the words "verily and indeed taken and received" seem to be inserted purposely to exclude any metaphorical interpretation of the terms Body and Blood.

This is clear; but no less clear is it that in these questions and answers of the Catechism, our Church is most careful to keep distinctly apart this inward spiritual feeding on Christ's Body and Blood, and that ontward visible feeding on bread and wine; our Church teaches us that the two go on concurrently, and that we are not to have one without the other, but the two are not to be confused ; (it wonld, in the language of the xxviiith Article, "overthrow the nature of a sacrament" to suppose the two parts made one. But of this presently.)

Of the outward and visible feeding we are not now speaking; let us fix our thoughts exclusively on the inward spiritual feeding, and reverently inquire what we are to understand by it. Holy Scripture must be our teacher.

Twelve months before the institution of the outward visible sign, our blessed Lord had spoken at

1 "Concurrently" is Hooker's word, borrowed perhaps from the ouvrpé $\chi_{\text {e؛ }}$ of Greg. Naz. Or. 40, and a most helpful word it is ; in fact, the key to our Church's doctrine of the Sacraments. 
some length of this inward spiritual feeding on His Body and Blood.

The discourse is given in the sixth chapter of St. John. The whole of that discourse is anticipatory, not anticipatory, necessarily, of the institution of the Eucharist, but assuredly anticipatory of that gift or grace of spiritual food which Christ intended to bequeath to His Church, and which $\mathrm{He}$ was subsequently pleased to secure to His Church by a special form of conveyance in the Eucharist. ${ }^{1}$

But of that special form of conveyance there is no mention in this chapter; our Lord speaks exclusively of an inward spiritual grace. What is it? Let the tenor of the discourse guide us to an answer.

Christ is first speaking to the Jews in their synagogue - in dark sayings, as usual. They had asked for bread from heaven like that which Moses had given. Christ replies that God will give them the true bread from heaven, of which the manna from the sky was only a type: $H e$ had come down from Heaven, $H e$ was the true bread from Heaven.

The Jews murmur at our Lord's thus speaking of Himself as One who had come down from Heaven. Our Lord replies that none can receive this truth of His Divinity unless he be "taught of God;" and

1 "Fateor nihil hic dici quod non in Cœnâ figuretur ac verè præstetur fidelibus; adeoque Sacram Conam Christus quasi hujus concionis sigillum esse voluit." - Calvin on John vi. 
that to those who thus receive $\mathrm{Him}, \mathrm{He}$ will be (as He had before said) a life-giving food: "I am the living Bread which came down from Heaven; if any man eat of this Bread he shall live forever."

At this point, namely in the 51st verse, our Lord introduces a new thought. His thought heretofore has been simply, "I am bread," " he that eateth $M e . "$ Now, for the first time, He mentions flesh, and two verses later flesh and blood; and now for the first time He uses the future tense: "The bread that I will give is My Flesh, which I will give for the life of the world ; " - pointing to a definite time when He would give the world this bread.

What is the meaning?

Clearly the meaning is that, as He then and there stood before them, $\mathrm{He}$ could not be their food: that His death was necessary, - the mention of the flesh and blood as in a state of separation implying death, and not only death, but sacrificial death: "Verily, verily, I say unto you, Except ye eat the flesh of the Son of Man, and drink His blood, ye have no life in you ;" - meaning, "Unless you feed on My sacrifice, you cannot be partakers of my Divine Life."

To the Jews in the Capernaum Synagogue all this was unintelligible, and to them no further explanation was given. Afterwards, alone with His disciples, He finds that they too had failed to understand Him. 
To them $\mathrm{He}$ vouchsafes an explanation (in v. 63). And first, of His having come down from Heaven that is, of His Divinity - He promises them a convincing proof in His approaching Ascension.

Then as to the life-giving efficacy of $\mathrm{His}$ flesh, $\mathrm{He}$ explains the necessity of its sacrifice and consequent glorification.

His mere flesh, as it then was, could have no such efficacy ; it must be glorified and spiritualized. Then, and then only, could it be life-giving food. "The words I have been using " - or rather, " the things I have been speaking of - Flesh and Blood - are spirit and life." By the flesh which they were to eat $\mathrm{He}$ meant the divine substance, and by the blood which they were to drink $\mathrm{He}$ meant the divine life, of His glorified Humanity. ${ }^{1}$

1 The interpretation of the $63 \mathrm{~d}$ verse here given is that of St. Athanasius ( $A d$. Serap. iv. 19), and is approved by Bengel and by Stier. Zuingle and others have understood the verse to mean that Christ's words and doctrine were the bread on which we are to feed; and that He called them "flesh and blood" metaphorically; and some of the Fathers seems to countenance the notion, but it is observable that where they do so, they are speaking to the uninitiated. As, for example, Cyril of Jerusalem in his Catechetical Lectures (xvi. 13, 14). But surely this is too cold an interpretation, and altogether insufficient (as Hooker says) to sustain the weight of those many sentences that speak of our incorporation with Christ, of our being in Him and $\mathrm{He}$ in us! Besides, if this were really all that our Lord intended, it would be not merely explaining, but explaining away - retracting - all that $\mathrm{He}$ had said before. St. Athanasius seems to give us the key to the passage, when he tells us that by the word "Spirit" in this verse, our Lord meant, not the Third Person of the Trin- 
Thus we have in the Capernaum discourse the doctrine of that inward and spiritual feeding on Christ, of which the Eucharist (instituted twelve months afterwards) is our surest means and pledge.

And by the help of that discourse we are in a position to define (as far as so great a mystery may be defined) the inward spiritual feeding, vouchsafed to us in the Eucharist.

\section{What is it? It is twofold :-}

It is (1) such a participation in the sacrifice made once for all by Christ upon the cross, - in His Body as then given, in His Blood as then poured forth, as makes us (2) participators of His Body glorified, and of His Divine Life, so that thereby "we dwell in Christ and Christ in us, we are one with Christ and Christ with us."

If, in reference to the first, any ask, How can we now partake of Christ's Body in that state of dissolution in which it was once, but is no longer?- we answer, Partaking of the sacrifice means partaking of the benefits of the sacrifice, which are abiding.

ity, but His own Divine nature ( this that His Human Body ascended to Heaven; and it was by virtue of this that this same Body became a life-giving food to mankind. So St. Paul : "The last Adam was made a quickening Spirit," 1 Cor. xv. 45. And so Athanasius hesitates not to say in another place, " $\pi u \in v \hat{\mu} a$ $\gamma \dot{a} \rho$

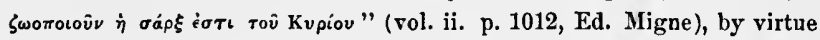
of the indwelling Divinity. He paraphrases Christ's words. "What I

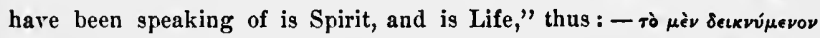

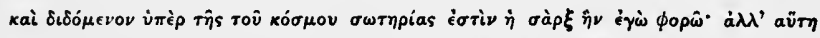

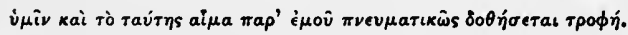


And if, in reference to the second, any ask, How can Christians in several places partake of the glorified Body of Christ, when it is "against the truth of a Body to be at one time in more places than one?" - we answer: - We do best to abstain from all speculation about the nature of the glorified Body of Christ. ${ }^{1}$ Suffice it to say, that where Christ's Body acts directly, there it may truly be said to be present, though it never leaves its session at the right hand of God. As the sun is said to be present wherever its light and heat are felt, so the glorified body of Christ is present wherever Christians are being strengthened and refreshed by its far-reaching power. But of this later when we come to speak of the Real Presence.

The important thing for us now to hold fast is this: - that it is verily and indeed the Body and Blood of Christ on which we feed; - though the manner of our feeding is spiritual, for by feeding on Christ's body we mean that Christ's body acts directly upon us, strengthening our souls as food strengthens our bodies. ${ }^{2}$

1 Bislop Thirlwall, in an appendix to his Charge of 1866, deprecates the line of argument adopted in the Protestation at the end of the Communion Office, showing how Leibnitz turned it against us.

2 Alexander Knox well expresses it: There is a substuntive communication from the adorable Person of onr Redeemer, quickening us with His divine vitality, and strengthening us with His strength;" and again: "We live by His life, are strong through His strength, and grow in grace by a vital effluence from Himself." - An Inquiry, on grounds of Scripture 
From that veritable Human Body of Christ, sacrificed for us eighteen centuries ago, and now glorified in Heaven, we derive, not only atomement, but also life and strength.

Let this suffice for our Church's doctrine of the inward spiritual grace promised by our Lord. We must now speak of the outward visible sign which $\mathrm{He}$ subsequently instituted, to be "a means whereby we receive the same, and a pledge to assure us thereof."

\section{The Outward Sign.}

We close the sixtl chapter of St. John, and open the passages that record the institution of the Lord's Supper. Remembering (as His Apostles would also remember) His promise that He would bequeath to them this spiritual food, - He purposed, the night before He suffered, to confirm and ratify the bequest most solemnly. That $\mathrm{He}$ viewed it as a bequest is clear from His own use of the word Covenant or Testament.

Wishing, then, to ratify it, He took up - what lay before Him on the table - the bread and wine. $\mathrm{He}$ broke the bread (so was His Body to be broken), and delivered it to each, saying, "Take, eat; this is My Body." He poured forth the wine (so was His blood and Reason, into the use and import of the Eucharistic Symbols, first printed 1824 ; published in Knox's Remains. 
to be shed), and delivered the cup to each, saying, "Drink ye all of it; this is My Blood of the New Covenant;" or, according to two of the four accounts, "this is the New Covenant in My Blood."

His Apostles could not fail to understand their Lord. When they saw Him thus solemnly place the bread in their hands, calling it His Body, and the cup, calling it His Blood of the Covenant, they could not fail to understand that $\mathrm{He}$ was intending to make bread and wine, then, and whenever so used in remembrance of $\mathrm{Him}$, a sacred pledge whereby $\mathrm{He}$ would convey to His Church in perpetuity the spiritual food which $\mathrm{He}$ had promised.

Those promissory words once spoken give to the bread and wine of our Holy Communion a force and an efficacy which it can never lose. As Chrysostom says so emphatically, "It is not man, it is not the priest, who gives them this force. It is Christ, who is Himself present presiding at the Holy Table. His word, once for all spoken gives them this efficacy; just as that other word once spoken, ' Be fruitful and multiply,' holds good, and retains its force to each succeeding generation." 1

I Hom. de Prod. Judæ, ii. 465. Alexander Knox has an excellent phrase: "Our Lord constituted the consecrated bread and wine the virtual representatives of His Body and Blood." And this explains very clearly and exactly the effect of the Consecration. Believing that Christ intended to connect His doing of the inward thing with our doing of the outward thing, we believe that our act and prayer of consecration establishes that 
In after ages, when men's minds were enslaved by a natural philosophy which taught that every cause produced its effects by some occult essence being infused out of the one thing into the other, we can hardly be surprised that they began to indulge in all sorts of speculations about the outward and visible sign of the Eucharist. They had lost the scriptural idea, that God acts directly by His Holy Spirit on the heart of man; and imagined that God worked according to their own theory, by infusing a secret something into the bread and wine, which was invisible only because it was of so fine an essence.

Thus the schoolmen lowered the doctrine of the Eucharist into a refined materialism, by their theory of some secret change in the substance of the bread, which made it become the Body of Christ. And so with the wine. The theory was afterwards known by the name of Transubstantiation. Though unknown to the first four centuries, the theory more and more took hold of the popular mind, which found it easier to believe that the Divine gift came to them in this

connection. The act is simply a rehearsal of the Institution, the prayer is a petition that the outward and inward thing may go on concurrently - that we receiving these Thy creatures of bread and wine " may at the same time " be partakers of His most blessed Body and Blood. [To adopt the old illustration, it is as though Christ had left a deed of conveyance needing only our execution to make it effectual; and as though this consecration were that execution. It gives to the bread and wine a sacredness and a significance which they had not before: making them effectual means of claiming the promised gift which they symbolize.] 
visible form in the hand of the priest, than that it came invisibly from the unseen Christ. Thus the doctrine prevailed, and, at last, was authoritatively sanctioned by Pope Innocent III., in A. D. 1215. The idea of transubstantiation being once suggested, the language of the early Fathers seemed to sanction it. For the early Fathers - having no fear of being misunderstood - habitually called the consecrated bread "the Lord's Body," and the consecrated wine "the Lord's Blood," for this simple reason, that Christ Himself had given them these names; ${ }^{I}$ without for one moment meaning that the bread ceased to be bread, or the wine ceased to be wine, - as abundant passages in the self-same Fathers prove. Their one desire was to guard against the opposite danger the only danger of their days - the danger of irreverent treatment of such sacred symbols. But in later ages the error of Transubstantiation was suggested, and though it never became universal, and though a continuous chain of authorities may be quoted against it all through the Middle Ages, yet it took such hold of the Church, that all that our Lord had said of the inward spiritual grace, in the sixth chapter of St. John, came to be said of the outward and visible sign.

Recoiling at last from the adoration offered to

1 So Tertuallian, $A d v$. Marc. iii. 19, and $A d v$. Jud. 10, "panem corpus suum appellans." 
created things, the great theologians of the sixteenth century went again to the early Fathers, and to the Holy Scriptures in their original language, and vindicated, once more, the higher and more scriptural teaching which is embodied in our Prayer-book, and which it has been the endeavor of this chapter to set forth with as much clearness as possible.

The idea of any change being wrought in the substance of the bread and wine seems to English divines (as our xxviiith Article declares) "repugnant to the plain words of Scripture."

And this in many ways :-

1. If any such change had been intended, the verb

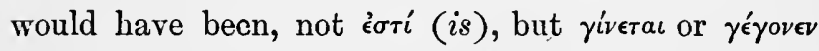
or $\gamma \epsilon v \dot{\eta} \sigma \epsilon \tau a \iota$ (becomes) ; as in Matt. iv. 3, "let these stones be made ( $\left.\gamma^{\prime} v^{\prime} \omega \nu \tau a \iota\right)$ bread;" and John i. 14,

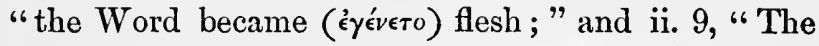

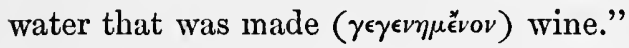

For our Lord's use of the verb '́ctí in this passage - is to be conceived as being-compare Matt. xi. 14, "If ye will receive it, this is Elias which was for to come," - where any literal interpretation of "this is" would be forbidden by John i. 21. So our Lord's words at the Last Supper are most naturally understood to mean that to all who will receive it the bread is in effect His body and the wine His blood. Compare also St. Paul's words (1 Cor. x. 4), "that rock was Christ." 
2. But the words of institution still more plainly forbid the idea of any transubstantiation. For, as though to guard us from so interpreting the words "this is My blood," the Holy Spirit inspired St. Paul and St. Luke to record the words " this is the New Testament in My blood." We must not give the words "this is" a force in St. Matthew and St. Mark, which they cannot possibly bear in St. Luke and St. Paul. Nor must we give them a meaning in "This is My body," which they cannot have in "This is My blood."

3. Again, St. Paul, in 1 Cor xi. 27, 28, continues to call the bread bread after consecration. And so our Lord (Matt. xxvi. 29 ; Mark xiv. 25) after consecration still spoke of the wine as the "fruit of the vine."

4. Again, our Lord did not say simply, "This is My body," "This is my blood;" but "This is My body broken," "This is my blood shed," which His body and blood were not as yet when $\mathrm{He}$ was speaking. The bread and wine symbolized, therefore, a future thing. They could not then be what was not to be until the morrow. Bishop Bull urges this argument as conclusive. (Corruptions of the Church of Rome.)

5. And, lastly, Transubstantiation and Consubstantiation are alike inconsistent with our Lord's assertion in John vi. 54, that all who eat His flesh and 
drink His blood have eternal life. If either of these theories be true, then all who eat the bread and drink the wine, eat the flesh and drink the blood of Christ, and therefore have eternal life, however wicked they may be. And this cannot be true. (This is the argument of our xxixth Article, drawn from St. Aug. Tract in Joan. xxvi. 18.)

\section{The Sacrifice.}

We have now considered "the inward gift" and the "outward sign" or symbol; let us, in the third place, consider in what sense the English Church allows us to call the Eucharist a sacrifice.

Our Prayer-book regards it as a sacrifice in three ways :-

(1.) First there is the "oblation" or "offertory" of our substance. In humbly presenting and placing on the Holy Table, not only the contributions of the people, but also (what in old days used to be included in those contributions) the bread and wine for use in the Holy Communion, our Church preserves a reminiscence, at any rate, of "the thank-offering of the fruits of the earth," which in the primitive Church ${ }^{1}$ was considered so essential a part of the Eucharist that the word Oblation ( $\pi \rho \circ \sigma \phi \rho \alpha$ ) was habitually applied to the whole service, and the name Altar given to the Holy Table, as that whereon the

1 Clem. Rom. i. 40, 44; Justin Martyr, 1 Apol. 65, 67 ; Iren. iv. 18. 
Christian "meat-offering" (mincha) was presented to the Lord. So in the Epistle to the Hebrews we read: "To do good and to communicate forget not, for with such sacrifices God is well pleased." (xiii. 16.)

(2.) Next, there is what the Prayer-book calls "this our sacrifice of praise and thanksgiving." This is the sacrifice which St. Peter speaks of as the Church's "spiritual sacrifice" (1 Peter ii. 5); and the Epistle to the Hebrews as "the sacrifice of praise, that is, the fruit of the lips." (xiii. 15.) And this is the sense in which the early Fathers loved to see in the Eucharist a fulfilment of Malachi's famous prophecy of the Gentiles' incense and pure offering. ${ }^{1}$ (Mal. i. 11.)

(3.) Thirdly, there is the sacrifice of ourselves: "Here we offer and present unto Thee, O Lord, ourselves, our souls and bodies, to be a reasonable, holy, and lively sacrifice" - words taken from Rom. xii. 1. With this sacrifice of ourselves the early Fathers ${ }^{2}$ connected the thought that we are the mystical body of Christ, so that in this sense the Body of Christ may be said to be offered under the symbol of the bread. St. Paul's words justify the idea: "For we

1 Justin Martyr, Dial. 116 ; Iren. iv. 17, etc.

2 Cyprian's Epistle to Cacilius, 1xiii. And St. Augustine's two Sermons, ccxxvii. cclxxii. ad Infantes. 
being many are one bread and one body." (1 Cor. x. 17.) $)^{1}$

In all these three ways, it will be observed, the sacrifice is of the Eucharistic kind. Of any propitiatory sacrifice in the Eucharist our Prayer-book says not a word. The doctrine of a propitiatory sacrifice is not that of the Anglican but of the Roman Church. The Council of Trent teaches - not, indeed, that the sacrifice of Christ on the Cross is repeated - but that an oblation of Himself, which they suppose Him to have made in the Upper Chamber is repeated in the Mass; and that the Mass thus becomes a propitiatory sacrifice, effectual for quick and dead. ${ }^{2}$ This doctrine is plainly repudiated in the opening words of our Consecration Prayer, which assert that Christ made only "one oblation of Himself once offered" on the Cross, and therefore deny that any such anticipatory oblation was made in the Upper Chamber, or that if made it could be repeated.

1 It might be worth while to inquire whether it was not this early idea that the bread symbolized not only the Lord's Body crucified (which is not offered in the Eucharist), but also His Body mystical (the Church), which is offered, which led, through a subsequent misinterpretation, to the error of the Sacrifice of the Mass.

2 Sess. xxii. can. 2. Si quis dixerit in illis verbis hoc facite in meam commemorationem Christum non instituisse Apostoles sacerdotes, aut non ordinasse, ut ipsi aliique sacerdotes offerrent corpus et sanguinem suum, anathema sit.

Can. 3. Si quis dexerit missæ sacrificium non propitiatorium ... neque pro vivis et defunctis, anathema sit. 
But while the Consecration Prayer thus emphatically denies that there is any propitiatory sacrifice of Christ's body in the Eucharist, it affirms no less clearly, and the whole Service proclaims, that it is the memorial of that full, perfect, and sufficient sacrifice of Christ. We therein " continue a perpetual memory of that His precious death until His coming again," and we receive the bread and wine "in remembrance of His death and passion." We thus fulfil our Lord's command, doing it " in remembrance of Him," and St. Paul's command, showing or annunciating "the Lord's death until He come again." In the very solemn recital with which our Consecration Prayer begins, we are pleading that Death before the throne of grace. This pleading of the sacrifice of the death of Christ in the Eucharist should never be lost sight of.

We may sum up all by saying that, in relation to the death of Christ, the Eucharist is not a sacrifice, but the memorial of a sacrifice, and a feast upon a sacrifice. ${ }^{1}$

\section{The Real Presence.}

The best safeguard against the unholy error of supposing that we in any sense sacrifice Christ in the Eucharist, is the true doctrine of the Real Presence as taught by the Church of England.

1 This view of the Eucharist, as a feast upon a sacrifice, was suggested by Cudworth in his youthful treatise, A True Notion of the Lord's Sup. per, 1642; and is defended by Waterland. 
By the Real Presence we mean, - not merely the real presence of the Gift, - but also the real presence of the Giver, - there presiding in His living glorified Person, and there dispensing the Bread of Life which He promised.

But this may need some further explanation. It may be asked, "Is He not always present with His Church, according to His promise?" (Matt. xxviii. 20.) We answer, Yes; but in the Eucharist we believe that we have a specially effectual presence. As in the narrative of the healing of the paralytic (Luke v. 17), Christ had been many days present in Capernaum, yet on that particular occasion, in some especial way (we are told) - perhaps because of the receptivity those of assembled - "the power of the Lord was present to heal them;" so we believe that our faithful performance of what $\mathrm{He}$ commanded, in our consecration of the elements, claims and calls forth a special fulfilment of His promise to be in the midst of us, where two or three are gathered together in His name.

Present by contiguity of place $\mathrm{He}$ in His Human Nature cannot be until the Second Advent; but present by spiritual power $\mathrm{He}$ in His Human Nature may be, and must be, if that Human Nature is to act directly upon us in this holy Sacrament. ${ }^{1}$

1 The difficult subject of the spiritual presence of Christ's Human Nature is admirably treated in Wilberforce's Doctrine of the Incarnation, chap. $x$. But see note 1, on p. 158, supra. 
Therefore, the more strenuously we deny that the elements either are, or contain, Christ, the more urgently should we insist on His most real presence presiding at our feast invisibly, and in the spiritual power of His glorified Manhood dispensing to all faithful communicants the vital efficacy of His Body and Blood.

Thus both are really present, - the Giver and the Gift; and both invisibly and spiritually.

It is to the Giver that our Eucharistic adoration is due.

Thus, whereas in other acts of worship it is we who are drawing near to Christ, in the Eucharist it is Christ who is drawing near to us. The deep comfort of this, especially in times of dejection, or illness, or weakness of faith, is known to many of us. In such seasons the Holy Communion seems indeed to place us on a rock that is higher than ourselves.

Thus, to repeat in conclusion the all-important truth with which we began, - we do not receive Christ " in a figure" only, in Holy Communion. The doctrine of our Church makes all clear. There are two most real things given in the Lord's Supper, the bread given by the priest, Christ's body given by Christ. Both are most really received, and the one is the symbol and token of the other.

If the purpose of this chapter has been at all fulfilled, it will be seen that there is, indeed, a profound 
mystery in the Holy Communion; but it lies not in the outward visible sign, but in the inward spiritual gift or grace.

In the bread and wine we see nothing but God's creatures, consecrated or set apart for a very sacred purpose, in obedience to His command, and as pledges of His promise.

But while we are receiving from the priest this simple bread and wine, we believe that the faithful are at that self-same moment receiving and (by the hand of faith) taking from Christ the spiritual food which $\mathrm{He}$ promised to bestow; and we believe the profound but blessed niystery that this spiritual food is no less than His own divine substance and life, by participation in which the faithful Christian enters into a communion with his Lord which death cannot end, or even interrupt. We believe, further, that all who enter, or have in previous ages entered, into this communion with their risen Lord, are thereby bound together in holy fellowship one with another also. And to this holy fellowship of those whom the Spirit has sanctified, one with another and with their Lord, we give the glorious name of the Communion of Saints.

Thus both Sacraments may be said to find mention in our Creeds, the one Creed bidding us acknowledge one Baptism for the remission of sins; and the other bidding us believe in the Communion of Saints. 


\section{PART II.}

ON THE SOTERIOLOGY OF THE BIBLE.

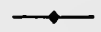

\section{CHAPTER I.}

THE SOTERIOLOGY OF THE OLD TESTAMENT.

BY the Soteriology of the Bible we mean the Doctrine of the Messiah's mediatorial work for man's salvation, as gradually revealed in Holy Scripture. These.scattered revelations may be conveniently arranged in groups under the following heads :-

I. The teaching of Moses;

II. The teaching of the Psalms and Prophets;

III. The teaching of the Gospel narrative;

IV. The teaching of St. Paul ;

V. The teaching of the Epistle to the Hebrews;

VI. The teaching of St. Peter;

VII. The teaching of St. John.

\section{THE TEACHING OF MOSES.}

That Moses wrote of Christ (John v. 46), and of his sufferings and resurrection (Luke xxiv. 27, 44, 46), is plainly told us. We turn to the five books of Moses for an explanation. 
1. We find on the very first page the doctrine of Sacrifice. And what is the doctrine of Sacrifice? It is closely connected with the doctrine of the Fall. Man has an animal nature; and he has also, breathed into him by God, a spiritual nature. He is free, but responsible. On this responsibility special emphasis is laid. In the day that he should set up his self-will in opposition to the Divine will he should die. (Gen. ii. 17.) He did so separate his will from God's will, and he died, $i$. e., death and corruption began to work in him. His life was forfeit; and he held it henceforth only as a reprieved life, on sufferance. God required acknowledgment of this; and the mention of Cain and Abel's sacrifice in close connection with the Fall is clearly intentional. Cain's sacrifice was a thank-offering merely; whereas Abel's contained an acknowledgment that his life was forfeit. God revealed to the two brothers that $A$ bel's was the kind of sacrifice that He preferred. Cain murmured, God replied, that if he were sinless, the thank-offering would be acceptable; but that, as he was a sinner, a sin-offering was needed, and might easily be offered ("lieth at the door"). "Offer that, and thou shalt retain thy primogeniture." 1 This appears to be on the whole the best interpretation of the pas-

1 Gen. iv. 7. "Unto thee shall be his (Abel's) desire." "ëxetv бe

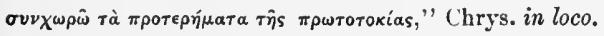


sage as it stands in the original Hebrew $;^{1}$ and so interpreted, it supplies, what the Israelites might fairly expect from Moses, some account of the institution of the sacrifice of living animals. Here, therefore, and all through the Pentateuch, we find this truth insisted on, that man's life is forfeit, and that sacrifice is the appointed acknowledgment of this.

2. But the teaching of Moses goes deeper. Did he intend the Israelite to understand that the sacrifice of the animal life really obtained for him the reprieve of his own life? Not for one moment: nor could the Israelite suppose that the life of a dumb beast could be accepted as an equivalent for his own life. The animal sacrifice did not redeem him; it was only the appointed acknowledgment that he needed a Redeemer and was expecting one. All that the homage of sacrifice obtained for him was a respite of his forfeited life, until a really effectual redemption should be accomplished. And Moses clearly teaches that such a redemption of man - from that bondage to his lower animal nature into which he had fallen - was, from the very first, promised. The Evil One, who, through this lower animal nature

1 The LXX., misled by the masculine $ץ$ ץר, separated it from $ר$,

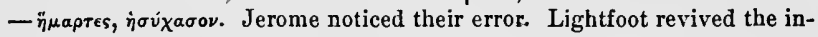
terpretation suggested by Eusebius, and given in the text (see Lightfoot's Works, ii. 1085, 1243). Then it was pointed out that תט of sin-offering is construed elsewhere as masculine. (See Ex. xxix. 14; Lev. iv. 21, 25 ; v. 9.) 
(aptly represented by the Serpent), had seduced man to his fall, received this sentence: "I will put enmity between thee and the woman, and between thy seed and her seed; it shall bruise thy head, and thou shalt bruise his heel." (Gen. iii. 15.) The lower nature was to inflict suffering on the seed of the woman, but the seed of the woman was to triumph finally over it. Thus, on the first page of the Bible, we find this deep truth written, that sin cannot be undone without suffering; and we find sacrifice instituted to give continual expression to it.

The main purpose of the Book of Genesis is to show how this promise of eventual deliverance was renewed to Abraham, and again to Isaac, and again to Jacob, by a special covenant - "the seed of the woman" being successively narrowed to the seed of Abraham, then to that of Isaac, then to that of Jacob.

And as the promise is repeated, it becomes more definite.

Along with the renewal of the promise, each of these Patriarchs is drawn into closer and closer covenant and communion with a mysterious Heavenly Visitor, who appears and speaks to him in the name of God. It is this Divine Person who is to be their Redeemer from evil. (Gen. xlviii. 16.) And yet it was one of their own seed in whom all the nations of the earth were to be blessed. Here was a mystery. 
They could not solve it; but they clung in life and in death to the promise. For Moses makes it clear to us that, in dying, these Patriarchs did not cease to be in covenant with God. Abraham is confident, that even though Isaac die, yet in him shall all the nations of the world be blessed. Very strikingly does dying Jacob, foreseeing how the old heel-biting serpent would show itself in one of his sons, bethink him of the primeval promise, and cling to it hopefully even on his death-bed - "I have waited for Thy salvation, O Jehovah!" He has waited, and he is still waiting; and even though he go into the other world, he will still be waiting, for the Redeemer, who is to be one day manifested in his seed, and whom he mysteriously identifies with the Angel whom he had learned to know, with whom he had wrestled in prayer, and who had redeemed him from all evil. (Gen. xlviii. 16, and xlix. 18.)

3. But not only is there an Angel of the Divine Presence with whom they and their seed are in covenant, but with this covenant the doctrine of sacrifice comes to be more and more closely connected.

In that narrative which the Church with a true instinct has ever connected with the doctrine of Christ's atonement, - the twenty-second chapter of Genesis, read on Good Friday, - we see how God burned into Abraham's mind the deep truth, that though redemption was promised in Isaac, yet it must be by way of sacrifice. 
Abraham had believed the promise of a Redeemer, and had hailed with joy ${ }^{1}$ the earnest of its fulfilment, - the germinant dawn of the "day of Christ "-in Isaac's birth. Then came the trial of the further revelation, that God could only redeem the life of man when man surrendered his life to God. Abraham was equal to the trial, and received back from God the dear life that he had surrendered.

Life through and beyond death, then, was the meaning of the redemption promised; Abraham accepted this fuller revelation of "the day of Christ," and "was glad."

With eager hope he had expected the day of redemption when Isaac was born to him; then came the agony of the process whereby God taught him how the redemption was to be accomplished; and yet it issued in life as a resurrection from the dead, ${ }^{2}$ and "he was glad." 3

This is the first unfolding of the doctrine of sacrifice in connection with redemption:- Life through death;-Man had fallen into his lower nature, and could only rise into his higher by the process of dying to the lower.

4. In the deliverance from Egypt, and in the sac-

1 Professor Stanley Leathes is surely right in seeing a reference to the

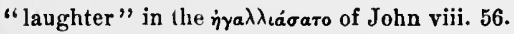

2 Heb. xi. 19.

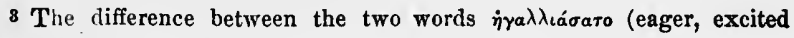
hope) and $\dot{e} \chi \dot{x} \eta \eta$ (a calmer, holier joy) is to be noted. 
rificial ritual of Sinai, the lesson was repeated and developed, that man's life was forfeited by the fall, and could only be redeemed by being surrendered back to God symbolically ${ }^{1}$ in sacrifice. When Jeliovah redeemed them from Egypt, He elaimed all their first-born; and the Paschal Lamb was the prescribed acknowledgment that they owed their lives to God. Under the covenant of Sinai there was the acknowledgment of a daily offering - the lamb of morning and evening sacrifice, - and to the maintenance of this every Israelite was to contribute his half-shekel or "atonement money," 2 for it was a "ransom for his soul to Jehovah." 3 Thus was every Israelite edncated to understand that his life was forfeited, and that he was only reprieved on condition of a daily ac-

1 The life or soul of the animal offered symbolized the life or soul of the offerer. Hebrew seholars tell us that the correct rendering of Lev. xvii. 11 is as follows: "For the soul of flesh is in the blood: and I have given it to you upon the altar, to make an atonement for your souls. For the blood it is which makes atonement by means of the soul (that is in it)." It is to be regretted that our translators render "جy by " soul " and "life" so caprieiously. Moreover, wa (we are told) should be translated by means of the soul. "For the soul" would be expressed by the preposition Augustine's comment on this verse (Qu, in Lev. lvii.) is the following : "Ye must not eat the blood, because it is the prefigurement of that more preeious blood which shall make atonement, the word blood being used for that whereof it is a sign, namely the soul."

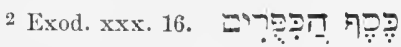

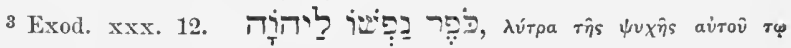
Kupiw. Expiation, not ransom, should be the word. See p. 173 . 
knowledgment that he was expecting a redemption; but the Redeemer was the Angel of the Covenant, and the redemption was still in the womb of the future. Of what kind this redemption was to be, was shadowed forth by an elaborate ritual; every part of this ritual being fashioned after a pattern which had been shown to Moses on the mount. (Heb. viii. 5.) Hence the threefold distinction of sacrifice into the sin-offering, which was to remove ${ }^{1}$ the defilement that excluded an Israelite from the sanctuary; the burnt-offering, which was to be an act of surrendering his whole self to God; the peace-offering, which was a sacred meal ${ }^{2}$ confirming the covenant. Once a year, as a sin-offering for the whole nation, came the great atonement; and once a year, as a renewing of the national Covenant, came the great peace-offering or eucharistic offering of the Passover. ${ }^{3}$ In all these sacrifices a mystical impor-

1 That the verb $N_{T}$ (nasa), when used in connection with the sinoffering, means not to suffer punishment for sin, but to remove and carry away the sin, is shown clearly by Lev. xvi. 22, where the live goat is said to bear or carry the iniquities into a land not inhabited. So in Lev. $\mathbf{x}$. 17, God says He gave the flesh of the sin-offering to be eaten by the priests, in order that they might so themselves bear away ( 1 ivin from Nivg the word to mean "elevation, portation, ablation." (See p. 219, infra.)

2 In the Peace-Offering alone was the offerer permitted to eat of his sacrifice.

8 For the elassifieation of the Passover in this third group, we have the high authority of Outram, De sacrificiis, lib. i. cap. 13, - "Illud forte si 
tance was attached to the treatment of the blood, which was not to be burnt nor eaten, but poured away at the foot of the altar. ${ }^{1}$ And again and again Moses impressed upon them the reason for this, - the blood is the life or soul, and the life or soul is forfeit to Jehovah. This symbolical pouring forth of life was essential to the sin-offering, essential to the burnt-offering, essential to the peace-offering. ${ }^{2}$ Without it there could be no atonement, no self-consecration, no entering into covenant.

How far all this ritual was understood at the time to be a foreshadowing of the redemption by the promised Seed of the woman, it is difficult, perhaps impossible, to say. But clearly the whole system of sacrifice was educational, grounding them in those doctrines of sin, and of man's fall, and of God's awful holiness, on which the doctrine of redemption rests. And we may safely say that, without this education, the Apostles could never have understood the work of Christ. When in those forty days that intervened between the accomplishment of His work

quæratur, quonam in victimarum genere sacrum Paschale ceuseri debeat, ego id in genere eucharistico commodè poni posse judico. Enimvero quamvis primum illud ipsâ in Egypto celebratum sacrificium ánотрónaiò erat, quo pestis tum Egyptiis imminens a familiis Hebræis averteretur, reliqua tamen deinceps omnia facta erant ob salutem Israelitis præstitam."

1 The word applied to the treatment of the blood in all these offerings is $P_{-\boldsymbol{T}}^{\mathbf{T}}$ (zarak) to pour out of a bowl, mistranslated "sprinkle."

2 See Lev. ix., where all these offerings are described. 
and $\mathrm{His}$ final departure, $\mathrm{He}$ "opened their understandings" to receive the doctrine of "His death, it seems to have partly been by unfolding to them this deeper teaching of the Books of Moses.

5. Let us endeavor to sum it up. From long familiarity we are perhaps hardly aware how largely our conception of what Christ has done for us rests on the teaching of Moses. I do not now allude to the doctrine of the Fall; that confessedly we owe to Moses; but I allude rather to the idea of a Divine Redemption from that Fall. Now here we owe to Moses two profound revelations :-

(1.) That there is, in the mystery of the Divine Being, One capable of entering into the closest relationship with man : One who made Himself known to Abraham, Isaac, and Jacob, and called them friends, promising that the blessing which they thus enjoyed should one day, through their seed, be extended to all the nations of the earth. This idea of a Divine Person, of human sympathies, speaking to man in the name of God, is one half of Moses' teaching.

(2.) And the other half is the doctrine of sacrifice. What was the Mosaic idea of sacrifice? First, we must notice this most important distinction between the Mosaic idea of sacrifice and the idea which prevailed among the heathen:- the heathen idea was that sacrifice was a gift from man to God, laying God under obligation; the Mosaic idea was that it was a 
gift from God to man, laying man under obligation. (See Lev. x. 17 ; xvii. 11.)

Next we must seize clearly the Mosaic idea of atonement. The death of the victim on the altar was vicarious, but in no sense penal. It never occured to an Israelite that an innocent animal was being punished in his stead. What was laid on the head of the goat or bullock was not the penalty of the sin, but the sin itself. The Israelite's thought was, " There goes my sin, separated and removed from me, by the mercy of God."

More than this was not disclosed. The sacrifices were symbols pointing onward to something in the reality of things, which, when it was revealed, would be found to interpret, and in fact to have suggested, those symbols.

II. THE TEACHING OF THE PSALMS AND PROPHETS.

To the teaching of the Psalms and Prophets we must now proceed. The two cannot be separated. The greatest of the Prophets summed up all his prophecies of Christ by saying that Jehovah would give them "the sure mercies of David." (Isa. lv. 3.) And St. Paul saw in these words, and expected his hearers to see, a convincing prediction of Christ's resurrection. (Acts xiii. 34.) Now what is the explanation of this? The almost hopeless difficulty of the question to all of us, when we first approach it, may 
well remind us of the need of searching the Scriptures before we profess to understand their deeper teaching about the work of Christ.

We have seen that under Moses the Israelites had learned to rest all their lope and trust on having a Divine Presence tabernacled in the midst of them, and a Priest to make atonement for their sin. The idea of both conditions being fulfilled in one Person does not seem to have been as yet suggested. But in David's Psalms the possibility of a Messiah, in whom these two ideas should coalesce, is gradually shadowed forth, and the prophet Isaiah gives it further definition.

To trace this development is most instructive.

It seems to have begun thus: David, rising to a grander conception of his nation's destiny than any Israelite before him, had set his heart on providing a worthier Tenple for the Divine Presence that tabernacled in the midst of them. But the prophet of the Lord forbade it, promising, at the same time, that his wish should be fulfilled by a son who should be born of his seed. "When thy days be fulfilled, and thou shalt sleep with thy fathers, I will set up thy seed after thee, which shall proceed out of thy bowels, and I will establish his kingdom. He shall build an house for my name, and I will establish the throne of his kingdom forever. I will be his Father, and he shall be my Son." (2 Sam. vii. 12, 13.) 
David, as humble as he was holy, accepted the promise as fulfilling all his heart's desire. And a whole series of Psalms show how continually he pondered over the promise, and unfolded the brief terms of the prophecy more and more, as the Holy Spirit enabled him. For there was much of mystery involved in it, as he at once saw :- "Then went King David in, and sat before the Lord; and he said, Who am I, O Lord God, and what is my house, that Thou hast brought me hitherto? And this was yet a small thing in Thy sight, O God; but Thou hast spoken also of thy servant's house for a great while to come. And is this the manner of man, O Lord God?" "I will be his Father, and he shall be my Son:" - the Son of David, and the Son of God! The thought reappears in his Psalms, - "The Lord hath said unto me, Thou art my Son, this day have I begotten thee." (ii. 7.) "He shall cry unto me, Thou art my Father." "I will make him my first-born, higher than the kings of the earth." (lxxxix. 26, 27.) Then again the promise of eternal duration made a deep impression of his mind: "His seed will I make to endure forever, and his throne as the days of heaven." (lxxxix. 29.) Solomon is born to him, but Solomon cannot fulfil these conditions; he can only prefigure the greater Son. The greater Son must be Divine; and as Divine he hymns His glory: "Thou art fairer than the children of men; grace is poured into thy 
lips ; therefore God hath blessed thee forever. Gird thy sword upon thy thigh, O most mighty, with thy glory and thy majesty. Thy throne, O God, is forever and ever: the sceptre of thy kingdom is a right sceptre." (xlv. 2, 3,6 ; compare Heb. i. 8.)

Then, with this idea of His divine royalty, there mingled also the idea that $\mathrm{He}$ would be a Priest forever; and yet not of the Levitical order, nor offering Levitical sacrifices, but of a higher order and offering more spiritual sacrifices, _ "Thou art a Priest forever, after the order of Melchizedec." (cx.4.) Speaking in the person of this promised Son, on whom his thoughts in the latter years of his life were ever dwelling, he says, "Sacrifice and offering Thou didst not desire; mine ears hast Thou opened" (to understand the deeper doctrine of sacrifice); "burntoffering and sin-offering hast Thou not required. Then said I, Lo, I come; in the roll of the Book (of the Covenant) it is written of me, that I should delight to do Thy will, O my God."' (xl. 6, 7, 8.)

But into this vision of his promised Son there entered also the bitterness of suffering. Before the Divine Son should ascend His throne, He was to pass through suffering. Most mysteriously this truth seems to have been borne in upon David's consciousness by the Holy Gliost. David himself had passed through the valley of humiliation to his throne; and in his prophetic vision his own consciousness and that 
of his greater Son were not distinguished. No Psalm more clearly speaks of the promised Son than the eighty-ninth, — "His seed shall endure forever, and His throne as the sun before me;" and yet in the very next verse this presentiment of fearful suffering passes across his vision, - "But Thou hast cast off and abhorred; Thou hast been wroth with Thine anointed (Thy Messiah); Thou hast made void the covenant of Thy servant; Thou hast profaned His crown by casting it to the ground. . . . Lord, where are Thy former loving-kindnesses which Thou swarest unto David in Thy truth?" (Ps. Ixxxix. 3849.)

Now on this verse we must pause a moment: It contains two words which are taken up and repeated by Isaiah in the great prophecy referred to at the opening of this section. The Loving-KINDNEsses which Thou swarest in Thy TruTH (in Thy Amen) are the "Sure Mercies" - the Amen Loving-kindnesses ${ }^{1}$ - of which Isaiah speaks. And the word for loving-kindnesses, ${ }^{2}$ in the 50 th verse, is the same as the word used for Thy Holy One ${ }^{3}$ in the 20 th verse of this same Psalm. The loving-kindness was in fact the giving of this promised Holy One. What then meant this vision of suffering? Would the

1 The word for sure in the Hebrew is the passive participle of (aman) to confirm ; whence "Amen."

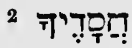

$$
\begin{aligned}
& 8 \text { חִִָירֶף }
\end{aligned}
$$


"Amen" of God's promise fail? No! the 16th Psalm supplies the answer — "God would not suffer His Holy One to see corruption." The Holy One was to descend into Hades, but only to rise again and fulfil the Divine Word, and reign gloriously and forever on the throne of David. Thus St. Panl and thus Isaiah understood the promise to David. There was folded up in it a prophecy of a Resurrection from Death of this Son of David.

But why the death? We fail to discover in the Psalms any indication that the reason for the death was revealed to David. But in the latter portion of Isaiah's prophecies we find it.

Taking up, as we have seen, the promise of the Holy One made to David, the prophet recognizes Him in the "Servant of Jehovah" whom he saw in his own vision. All through these latter chapters this servant of Jehovah keeps reappearing; and the sufferings of this Holy One, which had found such mysterious utterance in David's Psalms, begin to be explained.

Not only is this Servant of Jehoval to be one who will "feed His flock like a shepherd, gather the lambs with his arm, carry them in His bosom, and gently lead those that are with young" (xl. 11) :not only is $\mathrm{He}$ to be one who "shall not cry, nor lift up, nor cause His voice to be heard in the street;"

1 The same word again. 
one who shall not break "the bruised reed," nor quench "the smoking flax" (xlii.): but in that chapter, which has contributed more perhaps than any other single chapter of the Bible to the theology of the Atonement, the contrast between the exceeding sorrow and the exceeding majesty of the Messiah is set forth with a vividness that fills the reader with awe.

For what is there revealed? A Divine Person whose existence, when the prophet wrote, lay deep in the bosom of God, of such majesty that, when $\mathrm{He}$ should appear, kings should be dumb before Him (lii. 15), "exalted, extolled, and very ligh," and yet so capable of entering into fellowship witl human sin and all its consequences, that none would believe the prophet's report of Him, none would believe that $\mathrm{He}$ was the Arm of the Lord. He would be "despised and rejected of men; a man of sorrows, and acquainted with grief." His mission would be to bear our griefs, and carry our sorrows; and yet, so utterly would $\mathrm{He}$ be misjudged, that men would esteem Him stricken, judicially smitten of God. His sufferings would be an offence and cause of rejection; and yet His sufferings would be "the discipline of our peace," (learning obedience by the things that He suffered ${ }^{1}$ ) ; and by those sufferings He would heal

1 This verse of the Epistle to the Hebrews (v. 8) is the best commentary on the phrase which the LXX. and the Vulgate translate the "discipline 
us of our sin. Yes, He is the great Sin-bearer; the fulfilment df all those sacrificial types. It is "God so loving the world," that in the person of His Son $\mathrm{He}$ bears and takes away the sin of the world! $\mathrm{He}$ is the Lamb of God that taketh away the sin of the world; Himself dying the death of a sinner. $\mathrm{He}$ is an Intercessor for evil-doers, even while $\mathrm{He}$ is reckoned one of them.

But again we mark the deep theology of these contrasts: The despised root grows up to a rich harvest of seed; the travail of His soul obtains the fulness of recompense; it is through death that $\mathrm{He}$ "divides the spoil with the strong," - enters "the strong man's house, and spoils his goods;" and by knowledge of Him shall many be justified.

Ve do well to read this passage, as the Church has ever read it in her Good Friday service, in silent awe. It is absolutely impossible to explain it away by help of the circumstances of the prophet's age, or of any age previous to the Christian era. It is and can only be a vision of the Messiah's passion. If any seek further explanation, St. Philip and St. Peter must supply it. . St. Philip was asked the very question: "Of whom was the prophet speaking? of Himself, or of some other?" Philip answered by preaching Jesus from this text. St. Peter (whose of our peace." Sצרפ (musar) is used sometimes for instruction, and sometimes for the chastisement that enforces instruction. 
second chapter shows how deeply impressed this passage was on his memory) answers in his first chapter the further deeply interesting question, "How far was the prophet conscious that he was speaking of Christ?" and he answers: "The Spirit of Christ, which was in Isaiah, was testifying beforehand the sufferings that must befall $\mathrm{Him}$, and the glories that should follow : but not for himself, but for the Christian Church, who should afterwards read it, was the revelation made."

For our present purpose the important points are the following:-

1. The context of the chapter makes it plain that the "Servant of Jehovah" of this chapter is to be identified with the "Servant of Jehovah" and Anointed One, spoken of so continually in this latter portion of Isaiah, given for a light to the Gentiles, and a salvation unto the end of the earth; connected, therefore, by an unbroken chain of Messianic promise with the seed of Isaac in whom all the nations of the earth should be blessed.

2. His sufferings are clearly the sufferings of a historic Person - the sufferings of one who is persecuted even to death because of his righteousness. And yet they are spoken of, with marked iteration, in the language of the sacrificial ritual. His blood is to sprinkle many nations; He is a Lamb brought to slaughter; He is a sin-bearer: His blood, or rather 
the soul that is in the blood, is to be poured out unto death, and to make a trespass-offering (the āshām

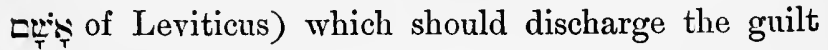
of many.

3. These sufferings are to issue in His exaltation, - "He shall be exalted, and extolled, and be very high." "He shall see His seed, and prolong His days" (so clearly is resurrection from death implied), "and the pleasure of the Lord shall prosper in His hand."

Thus in this wonderful passage the three grand revelations of previous Scriptures are brought together, and shown to be fulfilled in One Person: (1) He is the Angel of Covenant, whose manifestation in the seed of Isaac was foreshadowed in Genesis ; (2) He is the Priest who makes atonement, prefigured by the ritual of Leviticus, - only it is by pouring out His own soul unto death, and His soul thus poured out is to generate a Church ; (3) $\mathrm{He}$ is the Son of David, suffering, and yet living and reigning for evermore, of whom the Psalms are ever speaking. All these diverse presentiments of the holy men of old were to be harmonized and to find their fulfilment in One who, in the fulness of time, was to be historically manifested. 


\section{CHAPTER II.}

THE SOTERIOLOGX OF THE NEW TESTAMENT.

III. THE TEACHING OF THE FOUR GOSPLES.

To the historical manifestation of the Messiah we now come. We find it in the four Gospels.

And first we have to remark that their narrative contains indications that the whole Jewish people were at that time expecting $\mathrm{His}$ manifestation; and further, that the fifty-third chapter of Isaiah had largely helped to shape their conception of His character. They had apparently, since that prophecy was uttered, come to connect Him with the thought of sacrifice and atonement for sin. The exclamation of the Baptist - "Behold the Lamb of God!" was clearly intended to be a pointing out of the Messiah to his disciples ; and implies, therefore, that this was one of the many expressions by which the Jews had come to designate Him whom they expected. This must have been due to the deep impression made on the national mind by Isaiah's prophecy. ${ }^{1}$ We have

1 That this was so is abundantly proved by the Messianic interpretation of the chapter given by the Targums written before the Christian era. See Lyall's Propadia Prophetica. 


\section{THE SOTERIOLOGY OF THE BIBLE. 193}

a further indication that this was so in the words of Zacharias, who connects the salvation to be accom. plished by the Messiah with the sacrificial idea of remission of sins (Luke i. 77 ); and by the words of Simeon, who, with the Holy Child in his arms, spoke of suffering and persecution. Again we find St. Matthew forcibly reminded of the fifty-third of Isaiah, when he beheld Jesus entering into such close fellowship with human suffering: "He healed the sick," that it might be fulfilled which was spoken by Esaias (in this chapter), "Himself took our infirmities and bare our sicknesses." (viii. 17.) And again in Jesus' unwillingness to be known he recognizes at once Isaiah's portraiture : "Behold My Servant whom I have chosen; My beloved in whom My soul is well pleased. .... He shall not strive nor cry; neither shall any man hear His voice in the streets. A bruised reed shall He not break, and smoking flax shall $\mathrm{He}$ not quench, till $\mathrm{He}$ send forth judgment unto victory." (xii. 17-21.)

And how entirely the whole impression left on the mind by the Gospel narrative is that of a perfectly holy sufferer, fulfilling with almost startling exactness the image that rose before Isaiah's mind!

He moved among men as one conscious that $\mathbf{H e}$ was their Lord and Master, that he was born to be a King, that He was the Son of David of whose kingdom there was to be no end; but conscious also that 
He could only ascend His throne and be glorified by passing through suffering and death. The tempta-. tion suggested by the Evil One in the wilderness, and again by Simon Peter's ill-advised protest, was that He should ascend His throne without the suffering; but $\mathrm{He}$ repelled it. $\mathrm{He}$ had a baptims of suffering to be baptized with, and till that was accomplished, $\mathrm{He}$ must confine Himself ("straiten") Himself thereto. (Luke xii. 50.) It was entirely consistent with this view of His mission that $\mathrm{He}$ should speak little of the profound purpose of His death. But from time to time $\mathrm{He}$ used expressions of the deepest significance concerning it. Let us carefully consider them.

At the very outset of the ministry we have the conversation with Nicodemus, revealing the great truth that Christ had come to offer regeneration to mankind; and that in order to this regeneration His death was necessary: "As Moses lifted up the serpent ${ }^{1}$ in the wilderness, even so must the Son of Man be lifted up." (Three times ${ }^{2}$ our Lord used this phrase - "lifted up" - and the Evangelist's comment is, "This said He, signifying what death He should die.") And our Lord indicates to Nicode-

1 The symbol seems to point out that Christ would die "in the likeness of sinful flesh." See St. Augustine's comment on Rom. viii. 3, referred to infra, page 220 .

2 John iii. 14 ; viii. 28 ; xii. 32. 


\section{THE SOTERIOLOGY OF THE BIBLE. 195}

mus how His death would regenerate man: the believer would have a new vital principle, a divine life, infused into him: and that it might thus enter into man, it must first be poured forth by Christ. And this great gift to man is the Father's gift - it is allimportant to observe this - "For God so loved the world, that He gave His only begotten Son, that whosoever believeth on Him should not perish, but should have this eternal life (imparted to him)."

This thought is continually reappearing in our Lord's discourses as related by St. John, - that for this infusion of divine life which was to regenerate man, His death was necessary, and that it was His Father's gift to mankind: "My Father giveth you the true bread from Heaven. For the bread of God is He which cometh down from Heaven, and giveth life unto the world." "I am that bread of life." "I am the living bread which came down from Heaven: if any man eat of this bread, he shall live forever: and the bread that I will give is My flesh, which I will give for the life of the world." When the Jews nurmured, thinking $\mathrm{He}$ spoke of giving His flesh there and then to them, $\mathrm{He}$ added words, which to a Jew would necessarily carry the meaning that $\mathrm{His}$ death must first take place; for $\mathrm{He}$ explained that He meant His flesh and blood in a state of separation, that is, after death. "Verily I say unto you, Except ye eat the flesh of the Son of Man, and drink His 
blood, ye have no life in you" (ye cannot be regenerated).

The sacrificial allusion would have been plain to them but for that addition about drinking His blood. In all sacrifices the drinking of the blood was forbidden on pain of death.

To this paradox we must presently return; but first let us consider two other pregnant utterances of our Lord respecting His approaching death.

Not many months before it, He was speaking of Himself (in Isaiah's phrase) as "the Good Shepherd." But a further thought was added: "The Good Shepherd giveth His life for the sheep." We ask how? and why? The how is declared to us in the same passage: in conflict with "the wolf." (John x. 1-18.) And that He viewed His agony as a conflict with the Evil One is plainly revealed, as we shall see.

But why should the Good Shepherd lay down His life? He tells us, "This commandment have I received from the Father." It was an act of crowning obedience. And it was voluntarily rendered. "Therefore doth my Father love me, because I lay down my life, that I might take it again. No man taketh it from me, but I lay it down of myself. I have power to lay it down, and I have power to take it again. This commandment have I received of $\mathrm{my}$ Father." 
But do we ask further, "Why this commandment?"

One profound reason has been already revealed to us: there was a mysterious necessity that His human life ( $\left.\psi v \times \eta^{\prime}\right)$ should be poured forth in order that it might pass into man and regenerate him. This life of Christ was God's gift to man, and it involved the death of Christ as the essential condition of its communication.

And now we are in the right point of view from which to consider an all-important word spoken by Christ respecting His death the week before His Passion. We have it in St. Matthew (xx. 28), and in St. Mark (x. 45). Christ had been again announcing to His Apostles His approaching death, with all its fearful details ; the judgment and delivery to the Romans, the mocking, the scourging, the crucifixion, to be followed by resurrection. And the doctrine of this death is summed up in one word a few moments later: "The Son of Man came ....to give His life ( $\psi v \times \dot{\eta} v)$ a ransom for many."

This one word of Christ may be called the text of all that has ever been said about the virtue of Christ's death by preachers of the Cross inspired or uninspired. It is most important to consider carefully what meaning it bore as originally used by Christ. And here it is perhaps to be regretted that the question has been somewhat prejudged by the use of the . 
Vulgate word "redemptionem" and the English "ransom." The popular notion of a ransom is a price paid to redeem a captive or bondsman. And whenever the word is used, it seems to involve necessarily the idea of the price being paid to him from whom the captive is delivered. Dominated by this idea of ransom, divines, from Origen downwards, have been ever asking "To whom was mankind's ransom paid?" And the whole subject of the Atonement has been almost hopelessly complicated by this idea of its being a transaction between two parties, one giving and the other receiving a compensation or ransom. It has been roughly stated, ${ }^{1}$ that for a thousand years (down to Anselm's time) the Church taught that Christ paid, and the Evil One received, the ransom; and that, since then, the Church has been divided between the Anselmic notion of a transaction whereby the mercy gave satisfaction to the justice of God, and the Calvinistic idea of a transaction whereby the Son appeased His offended Father. A healthy conscience recoils from all three ideas. $\Phi \epsilon \hat{v} \tau \hat{\eta} s \tilde{v} \beta \rho \epsilon \omega s$ - out upon the insulting thought! - is Gregory Nazianzen's protest against the first; the second is artificial and scholastic ; the third shocks us. None of the three is to be found in Scripture. They all rest on a determination

I Oxenham's Catholic Doctrine of the Atonement, p. 167. The statement must be received with qualification. 
to press into the Greek word used by Christ all that is involved by the words redemptio and ransom. Whereas a careful study of the language of Scripture shows that the words $\lambda$ v́roov and ransom are by no meaus equivalent.

Let us carefully examine this word $\lambda \dot{v} \tau$ pov.

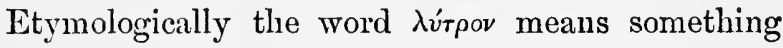
that loosens what is bound.

But, as a man may be bound in two senses - civilly, as a slave or captive, religiously, as a sinner by his sin, - so the word $\lambda$ v́rpov comes to have two senses a civil and a religious sense.

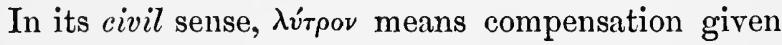
as the price of liberation. It is so used in Lev. $x x v$. 25-30, for the price paid to redeem the property or person of an insolvent debtor; the Hebrew word for

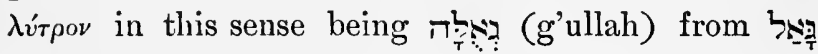
(ga'al) to redeem from pawn.

In its religious sense, $\lambda$ v́rpov means an oblation to God, or the money-value of such oblation ( $a$ deodand as it were), to redeem, or atone for, a life forfeited to God. The oblation usually took the form of the sacrifice of the life of an animal, by way of acknowledgment that the life of the offerer was really forfeited, and that all life is God's gift.

The $\lambda v^{\tau}$ pov in this case was expressed in Hebrew by the word (copher), a distinctly religious word, carrying with it the idea of atonement; and contain- 
ing obviously no notion of compensation to any one ; but rather that of satisfaction of the Divine law. We will call this the religious or sacrificial sense of the word $\lambda$ v́rpov.

To take one of the lower instances of its use : When an ox known to be vicious, gored any one to death, the proprietor's life, as well as that of the ox, was forfeit; but the proprietor's life might be re-

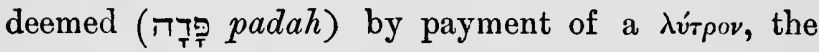
$\lambda$ úrpov being a ذَّ copher or oblation to God by way of atonement. ${ }^{1}$

But let us take a higher instance. On the Passover night the first-born of Israel were redeemed (padah, Exod. xiii. 13, 15) from the destroying angel by the blood of the lamb. This blood or life of

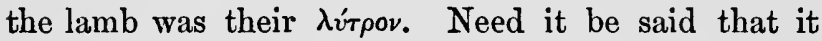
never entered the mind of an Israelite that it was given by way of compensation to the Destroying Angel? His only thought was that God required it as an acknowledgment that they owed their deliverance entirely to His grace, and that their lives henceforth belonged to Him. ${ }^{2}$ And in after years provision was

1 It seems to me clear that, in Exod. xxi. 30, the Copher levied went not to the relatives, but to the Sanctuary. It is true that in verse 32 , in the case of a slave being gored, compensation is made to the master, but the word Copher is not there used; nor was the life of the ox's owner forfeit to God in this case.

2 We have an excellent instance of the use of padah redemption witl copher for the $\lambda$ virpov in the forty-ninth Psalm: "None of them can by 
made for the continuance of the acknowledgment by the consecration of the tribe of Levi. Moreover, the whole people acknowledged that they were a redeemed people by the half-shekel payment, whereby the sanctuary service, with its morning and evening sacrifice of a lamb, was maintained. We have the full account of this in the thirtieth chapter of Exodus.

We there find the half-shekel called copher, or $\lambda$ útpov, " an offering to the Lord," " atonement money," "a ransom for the soul." (Exod. xxx. 1216. $)^{1}$ And in the twelfth verse we find that this con-

any means redeem ( $p a d a h$ ) his brother, nor give to God a ransom (copher) for him. . . . . But God will redeem ( padah) my soul from the power of the grave; for $\mathrm{He}$ shall receive me."

And for the word Copher, see that remarkable passage (to which Bishop Butler - Anal. ii. v. 6-calls special attention) where Elihu speaks of the "Angel of Jehovah" visiting the suffering saint on his death-bed, and regenerating lim, saying, "I have found an atonement." (Job xxxiii. 24.)

1 Professor Plumptre tells us (on the authority of Jost's Gesclichte des Judenthums, i. 218) that not long before the time of the incident related in Matt. xvii. 24, there had been a great controversy between the Pharisees and Sadducees whether this tax, or sanctuary-rate, ought to be compulsory or not; and that the Pharisees made it compulsory, and kept the anniversary of their triumph. This throws light on the demand for payment of this tax (or redemption-money) made upon our Lord, and on the deep meaning of His reply that "the children of the kingdom" ought to be free, - for was not $H e$ their all-sufficient $\lambda$ úrpov? It is worth noticing that on that

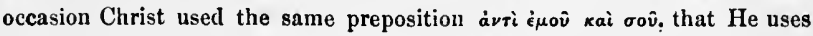

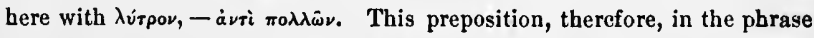

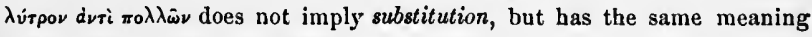
that it has in that other passage - payment on behalf of. Nor is the Hebrew preposition which expresses substitution ever used with Caphar, the

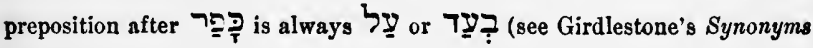
of O.T. p. 214). 
tinual confession that their lives belonged to Jehovah saved them from any plague.

Very much to the point is the note on this institution of the Sanctuary-tax-in the "Speaker's Commentary." Mr. Clark there observes: "This payment is brought into its highest relation in being here accounted a spiritual obligation laid on each individual, a tribute expressly exacted by Jehovah. Every man of Israel who would escape a curse (verse 12) had in this way to make a practical acknowledgnent that he had a share in the Sanctuary, on the occasion of his being recognized as one of the covenanted people. (Verse 16.)"

We have now perhaps sufficiently explained the two possible meanings of the word $\lambda \dot{\tau} \tau \rho \circ v$, one civil, the other sacrificial.

Can there be any doubt whatever in which of the two senses Christ used the word, when He said that $\mathrm{He}$ "gave His life a ransom, גúrpov, for many"? Do not the very time (the Passover season), and the evident reference to one or other of those great prophecies (Isa. liii. or Dan. ix.) make it clear that $\mathrm{He}$ used it in the sacrificial sense, - $\lambda$ virpov in the sense of expiation, the all-sufficing copher whereby, not Israel only, but a whole world, was to be redeemed? 1

1 Outram (perhaps the greatest authority I can quote on such a subject) is clearly of this opinion : - "Nemo dubitat quin quod Isaias olim dixerat, Messiæ animam pro $\square \underset{T}{\sum_{T}}$, hoc est, pro victimâ piaculari positum iri (Is. liii. 10), idem hoc in loco dixerit Christus; quod et eò minus dubitandum, quia 
If further proof were needed, St. Peter supplies it (in 1 Pet. i. 18, 19). For using the word '̇ $\lambda v \tau \rho \omega \dot{\theta} \eta \tau \epsilon$, and bearing in mind apparently its two meanings, he there negatives the first, the civil, meaning, and affirms the second, the sacrificial meaning, with direct reference to the Paschal Lamb.

And if this be so, then we must at once dismiss from our minds all idea of compensation or satisfaction of a debt. Our Lord's meaning is now clear: "The Son of Man giveth His life as a Copher, or expiation, for many."

For reasons lying deep down in the nature of things, mankind could not be redeemed without such expiation. Therefore God required it; and, in His exceeding love for man, gave His Son to make it. It was the cup of suffering of which Christ had spoken six verses before, and of which $\mathrm{He}$ spoke again in Gethsemane, as a cup which His Father had given Him to drink. It was the Asham of which Isaiah spoke in his fifty-third chapter. It was paid - not for one moment to the Evil One as compensation, nor yet to God as satisfaction of a debt-but to God in the true spirit of sacrifice, as an acknowledgment that the life of all mankind, summed up, as it were (recapitulated is the patristic word) in the life of the Second

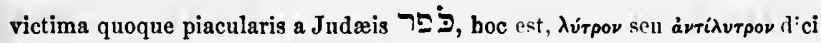
solet, victimæque anima sive vita vice sontis ipsius animæ dari." $-D e$ Sacr. ii. 6, §4. 
Adam, was forfeited to God. Until this acknowledgment was made, the higher life we had lost in the First Adam could not be restored to us by the Second.

We may sum up this long digression on the word

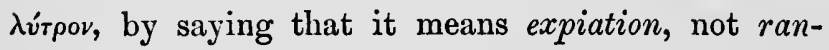
som.

How Christ in dying restored us to our higher life, we must now inquire. And in order to this, with all reverence, let us listen to our Lord yet further unfolding the deep-lying reasons why the pouring forth of His life-blood was necessary, in the innermost circle of His disciples, on the night preceding His Passion. How did $\mathrm{He}$ in that upper chamber show forth to them the profound efficacy of His Death? (Matt. xxvi. 26 ; Mark xiv. 22.)

He broke bread, calling it His Body, and bade them eat it. So far it might seem that Christ was merely speaking of His Death in the language of Jewish sacrifice, for the Lamb was even so eaten after it was slain.

But in what followed Christ went beyond the analogy of those sacrifices; and so virtually declared that there was a mysterious efficacy in His Death that had no counterpart in those sacrificial rites.

The blood in those sacrificial rites was to be poured 
away at the base of the altar. To drink it was forbidden on pain of death. ${ }^{1}$

Of Christ's blood the command is, "Drink ye all of it."

Let us compare and contrast the old and new commandment:-

The old commandment was: Whosoever eateth any manner of blood, I will even set my face against that soul that eateth blood, and will cut him off from among the people. For the soul of the flesh is in the blood; and I have given it to you upon the altar to make an atonement for your souls." (Lev. xvii. 10, 11.)

The new command was: Drink ye all of it: for this is my blood of the New Covenant, which is shed for many for the remission of sins."

Eating blood is forbidden in the first case for the very reason for which it is commanded in the second. For what is the reason? "The soul is in the blood." "For the blood it is which makes atonement by means of the soul." 2

But how could the blood of bulls or goats make atonement for man? The Epistle to the Hebrews (x. 4) plainly declares that it could not. What, then, is the meaning of this verse in Leviticus? St. Augustine surely is right in his interpretation : "Ye must not eat the blood, because it is the pre-

1 Lev. vii. 27.

2 See Note on p. 178. 
figurement of that more precious blood which shall make atonement by means of the soul therein signified." 1

Thus the two passages are reconciled. The blood of that animal must not be eaten because it is valueless except as a symbol. The blood of Christ is to be drunk, - or rather the soul which Jesus " poured out unto death" is to be infused into us, - because it is the real thing symbolized, and is of life-giving efficacy. ${ }^{2}$

And who shall say that in the mysteries of the spiritual world there may not have been a necessity that the life of Christ, the vital principle of Christ's human nature, should be surrendered in death before it could pass into us? At any rate the words of Christ in the sixth of St. John, and His symbolic act of breaking the bread and pouring forth the wine, in order that they might eat the one and drink the other, seem to suggest it.

But we have not exhausted the teaching of our Lord's words - Drink ye all of it; for this is my Blood of the New Testament for the remission of sins.

"A covenant for remission of sins" is here our Lord's phrase for the redemption $\mathrm{He}$ was accomplishing - a lifting of man into a new relation to God,

1 Quest. in Lev. Ivii. "Tanquam anima pro animâ exoret ;" soul atoning for soul. In the blood of the beast there was no soul that could be spir. itual food, therefore it must not be eaten.

2 See note on p. 271, infra. 
one of favor and forgiveness. Does any ask, Why should the blood-shedding and death of Christ be necessary in order that God should forgive? Why should not God forgive by a word?

If sin were a debt merely, it might be cancelled by a word, and the debtor taken at once into favor.

But if $\sin$ be also a disease and a corruption, will the word "I forgive you " heal it? and can God take the diseased and corrupt nature into favor, with no security for its being healed?

"Nay, but might not God by a word have healed the corruption?" Yes, by superseding, and in fact, destroying man's freedom of will. But it was the offering of a free heart that God desired in redeemed man ; and therefore God would not adopt a process of redemption that would compromise man's free will.

How then alone could it be done? Christ's words supply the answer, "By a Covenant," - God of His free grace undertaking to receive into favor, and man of His free will undertaking to die unto the corrupt nature.

But did God wait for mankind to fulfil their condition first?

No ; He accepted Christ as our surety in the covenant, ${ }^{1}$ as mankind's sponsor. ${ }^{2}$ Christ as the ${ }^{\hat{}} \rho \chi \eta \gamma$ os of

1 The $\tilde{\epsilon} \gamma \gamma$ os $\tau \eta \boldsymbol{s} \delta\llcorner\alpha \theta \dot{\eta} \kappa \eta s$ of Heb. vii. 22.

2 I borrow this word from our old divine, Dr. John Owen, quoted in 
our salvation fulfilled the condition, pledging mankind to fellow, and enabling them to do so at the same time, as we have seen. How completely does this idea find expression in that phrase of our Lord's High-priestly Prayer: "I consecrate myself that they may be consecrated." (John xvii. 19.) And again, in the equally pregnant phrase of St. Paul, "If one died for all, then all (virtually) died." Cor. v. 14.)

Thus His Death was necessary to the ratification of the covenant: and in virtue of the covenant so ratified by Christ as our sponsor, we are taken into God's favor. This surely is the true and catholic doctrine of Satisfaction. It may be stated briefly thus in the words of Athanasius : ${ }^{1}$

God's law of holiness required that there should be a death unto $\sin$ (Gen. ii. 17), ere there could be a restoration to favor.

This law was fulfilled by the sacrifice of Christ, inasmuch as all died in Him, and in Him took a new beginning of life.

Pole's Synopsis on Heb. v. 7. Hezekiah's prayer was, "O Lord undertake for me !" (Is. xxxriii. 14), which the Vulgate translates, "Responde pro

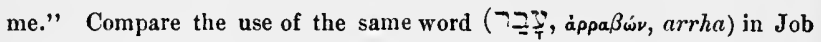
xvii. 3 ; Prov. xi. 15 ; xx. 16.

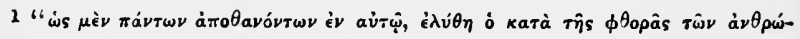

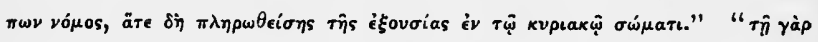

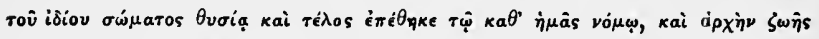

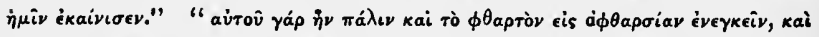

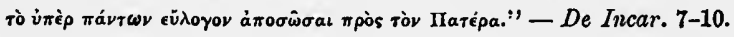


Thus man was saved while the supreme consistency of God's holiness was safeguarded.

And thus, in those few words of Christ in the upper chamber, we find two deep reasons why His Death was necessary : -

(1.) That the law which made the death of the old Adam a condition of a new Covenant of forgiveness might be satisfied;

(2.) That His life might pass into us, and so enable us to fulfil our part in that Covenant.

But a yet third reason why His Death was necessary seems to be suggested by the one remaining utterance of that same evening which remains to be considered.

Leaving the upper chamber where He had been instituting the Eucharist, and going forth into the moonlight to Gethsemane, what was the deep thought that filled the Redeemer's mind, and which He spoke aloud? - " The Prince of the world cometh, and in Me hath nothing. But that the world may know that I love the Father; and as the Father gave $\mathrm{Me}$ commandment even so I do." (John xiv. 30.)

Our Lord, then, viewed His agony and Passion as a coming of the Evil One. And if a coming, then necessarily a coming for conflict, for final conflict. For one conflict there had been already at the commencement of His ministry, after which we were told that 
"the Devil left Him for a 8eason." The Evil One is now returning for the conclusive conflict, and the Saviour knows it. "The Prince of the world" is approaching. The conflict has not yet begun. Therefore the exceeding calmness of the Prayer as $\mathrm{He}$ went forth to the Kedron. (John xvii.) The Good Shepherd is yet for a few moments alone with His sheep, who know Him and follow Him ; and for them in the moonlight He lifts His eyes to Heaven, and prays in tranquillity of spirit. But " the wolf cometh," and He knows it. And in the deep shades of that garden the great trial or temptation is to commence. The consciousness of $\mathrm{His}$ being on His trial is implied in His words, "Pray that ye enter not into temptation :" $H e$ must enter into it.

Another moment, and it is upon Him. $\mathrm{He}$ is in the agony. The very word agony means conflict and struggle. The fearful account of it indicates intense spiritual effort called forth by something - by some one - external to Him. Else why so tranquil one moment, and so agonized the next? But we are left in no doubt: our Lord's own words - so calm again - so suddenly calm again, when for the moment it is over - reveal to us its nature: "This is your hour and the Power of darkness." (Luke xxii. 53.) It was with "the Power of darkness" - with him who in this dark hour had power " to bruise His heel," that $\mathrm{He}$ had been struggling, and was yet again to 
struggle (it may be) on the cross. What the mysterious necessity for that personal conflict was, we cannot know. Our Lord's use of the word "temptation" suggests the idea that this conflict, like that in the wilderness, was of the nature of a temptation. But we know that when the Son of God came into the world, He placed Himself within the precincts of that dominion which our sin had given Satan. We know, too, that there was in His incarnation an emptying of

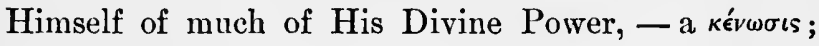
we know that the Divine Power whereby He worked His miracles was drawn from His Father in prayer, and never once in His ministry used for His own defence. We may well believe that the strong temptation, with which the Evil One in that hour of darkness was permitted to assail the human will of Christ, was a temptation to put forth His Divine Power to ward off Death, and ascend His throne without suffering. The Tempter's whisper, we may conceive, was " Thou shalt not surely die ;" and Christ's reply: "Get thee behind me, Satan. In the volume of the Book it is written of $\mathrm{Me}$ (that I should die), and I come to do Thy will, O God." Thus by dying $\mathrm{He}$ overcame the temptation, and so overcome the Tempter - overcame him "who had the power of death;" and death to Christ became the avenue to glory.

Other and deeper issues were doubtless involved in this conflict, which can only be revealed to us within 
the veil. That cry of exhaustion on the cross "My God! my God! why hast Thou forsaken Me?" - seems to imply that during that last hour the mysterious conflict was being renewed; and that the vital strength gave way, and the dissolution of soul and body supervened, rather from the exhaustion of this conflict, than from the mere pains of crucifixion. If so, additional force is given to those words: The Good Shepherd gave His life for the sheep : no man took it from Him : He had power to lay it down, and He had power to take it again. And voluntarily and for our sakes, and in obedience to His loving Father's will, because $\mathrm{He}$ would not put forth that Divine Power which might have averted it, He succumbed to Death. He had counted the cost; He knew that to redeem man He must place Himself within the power of him "who had the power of Death." But $\mathrm{He}$ knew also that by so yielding to the power $\mathrm{He}$ could destroy it, - " that throngh death $\mathrm{He}$ might destroy him that had the power of death, that is the Devil; and deliver them who, through fear of death, were all their lifetime subjects of bondage." (Heb. ii. 14, 15.)

Thus in this mysterious aspect of the agony, revealed to us by our Lord's own words, and interpreted by that profound commentary in the second chapter of the Epistle to the Hebrews, we seem to look into the very depth of that transcendent act of which it was the outward expression, and gain sight of a third reason why it was necessary. 
We must now sum up what we have gathered from our Lord's own utterances respecting His death.

From our Lord's words to Nicodemus respecting the new birth, and the type of the Brazen Serpent, we learn the healing and regenerating efficacy of His death, - it was life-giving death. This is further unfolded in the discourse of St. John's sixth chapter, where Christ speaks of giving His flesh and blood for the life of the world.

From the great saying that the Son of Man came

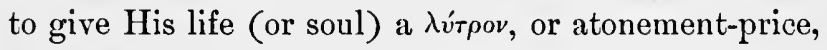
for many, we learn that His death had in it something which corresponded to the Jewish idea of expiation, a dying unto sin, rendering it possible for us to pass out of a previous state of alienation into God's favor.

Our Lord's words at the institution of the Eucharist combine both these aspects of His Death. In the "Take eat," "Drink ye all of it," we have implied the life-giving efficacy of His Death. In those other words - "My Body given for you," "My Blood of the New Covenant, which is shed for you and for many for the remission of sins," we discern the idea of expiation, and its meaning: God can only take back a free agent into favor by way of covenant; there must be a safeguard of the standard of holiness ; there must be a dying within us of the old Adam; and this was potentially effected in the Death of 
Christ. On credit that we would severally fulfil Christ's pledge we were forgiven. Thus His bloodshedding was necessary for this new covenant of forgiveness. ${ }^{1}$

From our Lord's saying in John x. about the Good Shepherd seeing the wolf coming, and laying down His life for the sheep, and from those words just before the agony, "The Prince of the world cometh," as well as from other indications, we seem to learn that one element of our Lord's agony was a conflict with the Evil One. And this, too, we shall find confirmed by the subsequent commentary of the Apostles.

More shortly we may sum up the teaching of Christ respecting His death by saying that it was

1. A crowning act of obedience, whereby the Tempter was overcome. - Luke iv. 13; xxii. 53. John x. 11,18 ; xiv. 30, 31.

2. An atonement, rendering possible a covenant of forgiveness. - Matt. xxvi. 28.

3. A gift to mankind of the spirit and life that was in His Flesh and Blood. - John vi. 51 and 63.

Those three petitions of the Lord's own prayer in which we ask for deliverance from the Evil One, forgiveness of our trespasses, and daily bread, seem to be a supplication that God will realize to each of us what His Son made possible for mankind.

1 Without the Epistles to the Romans and the Hebrews we should never perhaps have seen that this was the meaning folded up in our Lord's few words ; its further elucidation must be postponed until we are examining the teaching of the Epistles. 


\section{CHAPTER III.}

THE SOTERIOLOGY OF THE NEW TESTAMENT - CONTINUED.

IV. THE TEACHING OF ST. PAUL.

W $\mathrm{E}$ now have to consider how our Lord's Apostles, enlightened by the Holy Ghost, seemed to regard the redeeming work of Christ. And first we will examine St. Paul's Epistles.

In four of his Epistles St. Paul has occasion to speak in set terms of the work which Christ accomplished for mankind in dying on the cross. In all his Epistles he alludes to it; but the brief allusions of the other Epistles add nothing to the doctrine of the four more important passages. These, therefore, we will consider in detail. The fullest statement is in the Epistle to the Romans.

St. Paul's doctrine is strongly colored by the fact that he was a convert from Pharisaism. As a Phar-

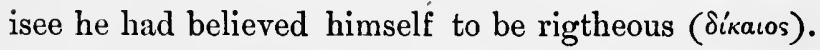
His conversion opened his eyes to the fact that this was in reality self-righteousness, and that the righteousness which is of God and which avails before God 


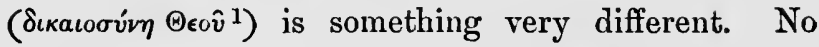
amount of observances ( if he be at heart selfish, proud, and worldly (баркско́s). We have within us a good self and a bad self (the spirit and the flesh). The Law has no power to redeem us from our bad self. The utmost it can do is to make us miserably conscious of our bad self. And this is the right point of view from which to approach the doctrine of Christ's atonement.

It may be useful to paraphrase the passages which set it forth.

ii. 23-26. All having sinned, we can only be justified (set right with God) by means of the redemption that we have in Christ.

God, in His eternal counsels, purposed that Christ should be to us what the mercy-seat ${ }^{2}$ was to the Jews, the source of all our hope of Divine favor, our trust being in His blood, that is in His sacrifice. God's purpose was to exhibit thus His own righteousness, — that is, His own mode of establishing a right rela-

1 That by "the righteousness of God" St. Paul means the righteousness which is of God, which God bestows npon us, by remitting our sins, is clear from Romans iii. 21-24, where he explains it to mean our being justified freely by $H$ is grace. It means therefore God's method nf justifying man, $i$. e., of putting him into a right relation to Himself. See p. 79 .

2 It makes no real difference in the import of the passage whether (with Chrysostom, Theodoret, Luther, Calvin, and Grotius) we translate i $\lambda a \sigma-$ ripıo as the "mercy-seat" on which the blood of the sin-offering was sprinkled, or (with the Vulgate and English version) as the "propitiation" which that sin-offering effected; or the sin-offering itself (with Alford). 
tion between Himself and mankind. He had overlooked transgression heretofore, and he would now vindicate this forbearance, and show that it had been in view of the coming atonement; thus proving Himself both just and justifying-just in requiring atonement, and justifying all who make faith in Christ their principle of action. ${ }^{1}$

In the fifth chapter the Apostle institutes a comparison or rather contrast between Adam and Christ, showing that the benefits resulting from Christ's work are co-extensive with the evils from Adam's fall. A reign of $\sin$ and death was developed from Adam's one sin; a reign of grace was developed from Christ's all-holy life.

v. 6-11. The Apostle dwells on the exceeding love of God in giving His Son to die for us while we were yet sinners. (Thus the Father's love was the moving cause, not the result, of the atonement.) "If, while we were yet sinners, Christ undertook by dying to render it possible for God to receive us into favor, much more will $\mathrm{He}$ now save us from again forfeiting that favor. For if while we were alienated from God, we were reconciled to God (made-atone with God) through the death of His Son ; much more surely shall we, now that we are reconciled, be saved in His life; that is, be kept safe in that divine life which we draw from Him."

1 Literally - him who is of faith in Jesus - i. e., him who is, or whose character is, the result of faith in Jesus. 
Then he goes on to institute a comparison between the reign of $\sin$ and death that dated from Adam, and the reign of grace and life that dates from Christ. It is clearly a mistake to see in this passage any doctrine of imputation. He is speaking simply of a propensity to sin which would never have been developed in the race but for the sin of Adam; and of a holiness which, after being once realized by Christ on

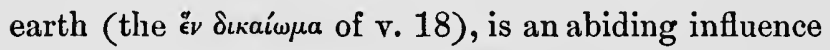
ever after.

Thus we see that in these two passages St. Paul is speaking of the passive and of the active work of Christ.

From the third chapter we learn what His passive work, His suffering, has accomplished for us: it has made atonement (at-one-ment or reconciliation to God), possible.

From the fifth chapter we see what the active work of Christ, His all-holy life, has done for us: it has given us a standard towards which the Divine life which He infuses into us is ever raising us.

In the next chapter (vi. 1-11) St. Paul seems to point to the very same solution of the mystery of atonement by death which we thought we found suggested by Christ's words at the institution of the Eucharist (supra, pp. 204-209). The whole force of the passage turns on the thought that in Christ's death we all died. Christ, as the head of the race, virtu- 
ally and potentially crucified mankind's worse self (the flesh, or old Adam), and so removed that which separated us from God and barred our restoration to favor. St. Paul gives ns a most helpful thought in saying that what Baptism is to the individual, that Christ's death was to the race: It not only pledged the race to mortification of the sinful self, but also imparted an inward and spiritual grace enabling all who would appropriate it by faith to work out this mortification of the sinful self.

Again this sacramental grace of Christ's death was twofold: (1) It enabled God to take us into favor by way of anticipation (the free gift of justification) ; and (2) It infused, into all who would receive it, $H$ is own divine life (the gift of sanctification).

"As surely as we are united with Christ in His death, so surely shall we be united with $\mathrm{Him}$ in His resurrection: knowing this, that our old self was crucified $^{1}$ with Christ, in order that the body, whereby (since the fall) sin has worked in us, might be rendered powerless, so that we should be no longer enslaved to sin. For a dead man is absolved from sin. And if we died with Christ, we believe that we shall also live with Him." (vi. 5-8.)

1 ovverravpwi $\theta_{\eta}$, was crucified. The tense is most important. The whole gist of the passage lies in the fact that it was done potentially, once for all, on Christ's Cross. Here and repeatedly elsewhere doctrine is obseured by the careless way in which our translators confuse the aorist and the perfect tenses. 
Thus Christ's death imparted to mankind a power of dying to sin, and a power of living in communion with God. And this its sacramental efficacy supplied that security without which God could not take back a fallen race into his favor.

But nowhere has St. Paul set forth his doctrine of the redeeming work of Christ more clearly or more succinctly than in the third verse of the eighth chapter ; and in St. Augustine's CLVth Sermon we have our best commentary on it.

There is now no condemnation hanging over the head of the Christian. Why not? Because the sinful self has received its condemnation on the Cross of Christ. How? St. Paul tells us how in the third verse, which fully and carefully translated is as follows: "That which the Law could not do - its weak point being that it depended for its performance on our carnal nature - that God in Christ effected. God sending His own Son, in flesh like that of sinful men, and as a sin-offering, ${ }^{1}$ passed sentence of death upon sin in that flesh which was its domain, that so in our regenerate nature we might fulfil the

1 The phrase repi ámaprias is used more than fifty times in the Book of Leviticus (as though written with a hyphen) for a "sin-offering." The Septuagint dropped the word offering, and spoke of "a for-sin." St. Augustine (155th Serm. \$ 8) says, "Peccatum vocabatur in Lege sacrificium pro peccato. Assidue Lex hoc commemorat: non semel, non iterum, sed sæpissime peccata dicebantur sacrificia pro peccatis. Tale peccatum erat Christus" (referring also to 2 Cor. v. 21). 
requirement of the Law, which in our unregenerate nature we conld not fulfil."

St. Paul's idea, as St. Augustine works it out, was that the Flesh of Christ, though absolutely sinless, was nevertheless to Him as to us the avenue of temptation. (Heb.iv. 15.) For this reason it was symbolized by the Brazen Serpent which Moses lifted up; and for this same reason - because herein the flesh of Christ was akin to our flesh - St. Paul in this passage

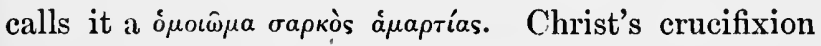
was therefore, according to St. Paul, the death-warrant of our sinful self, so redeeming our better self.

In the remainder of this eighth chapter St. Paul shows how, concurrently with that sentence of death against the sinful self, there came, streaming forth upon us from that same Cross, a vital grace, enabling us individually (if we will receive it) to enforce in our own case that foregone sentence, and so realize in our measure that sanctification to which Christ (as our surety) has pledged us.

We may now proceed to the three other Epistles in which St. Paul has occasion to speak fully of the redemptive work of Christ, and in each we shall find this same view of the Atonement reappearing.

2 Con. v. 14-21. After speaking of his work as an Apostle, he sets forth its great motive and purpose, which is to make known the Atonement and how it is to be appropriated :- 
"Christ's love for man constraineth us, our doctrine being that One died on behalf of all, ${ }^{1}$ therefore all died (that is, died potentially in Him): and he died on behalf of all, in order that they who yet live in this world should no longer live to themselves, but to Him who died and rose again in their behalf and as their surety."

It is important to observe that the preposition

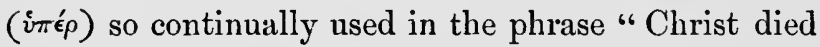
for us," here belongs to both verbs, "died and rose for us," - though the English translators have not so given it. Hence it cannot have the sense of doing a thing instead of another so as to relieve that other from the necessity of doing it. The very point of the Apostle's doctrine of atonement is that Christ died by way of surety that we would die with Him, and rose again by way of surety that we should rise with Him to newness of life. And it is this suretyship or sponsorship that is expressed by the preposition íté $\rho$. Two ideas are involved in it - (1) that Christ pledged us to do it, and (2) enabled us to do it. And this $\mathrm{He}$ did at a cost of great suffering, and (as St. Peter says) " the just for the unjust," i.e., for the benefit of men who were utterly undeserving.

In the sequel (16-21 verses) St. Paul works out this idea of the necessity of dying to the old self, and

1 The masterly note of Estius is well worth citing: "Unus pro omnibus, intellige, quoad sufficientiam pretii, non item quoad efficientiam." 
rising to newness of life, in order to reconciliation to God. God who, through Christ, made us originally good, purposed through Christ to renew us to goodness. "God was reconciling the world to Himself in Christ, notimputing to them (i.e., remitting to them) their transgressions, and charging us Apostles with this word of reconciliation. On Christ's behalf, therefore, we are ambassadors, as though God were exhorting you by us: we beseech you in Christ's behalf, be reconciled to God (i.e., make your own the benefits of that covenant which Christ executed for you)."

At this point a possible objection occurs to the Apostle which he must remove: "Before the covenant of reconciliation could be sealed, it was needful that the whole race should die to the bad self; and this (you say) it did in the person of its representative or sponsor, Christ. But how could that be? Christ had no bad self to die unto. St. Paul meets the difficulty by recurring to the sin-offering ${ }^{1}$ of the Mosaic Ritual. That victim had done no sin, had no bad self, but God accepted it as a symbol of the

1 That St. Agustine is right in interpreting áapriav here as "sin-offering" seems clear when we remember how exactly the word corresponds with 7 NiT (chattath) which is used for both sin and sin-offering. See

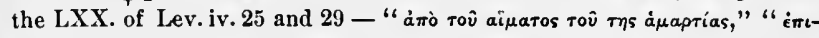

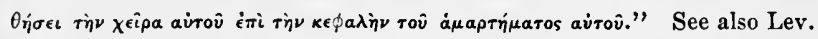
vi. 25, xvi. 9, and Num. vi. 14 . It is discussed in St. Aug. Sermons CXXXIV., CLII., and CLV. (vol. 5). See also Schleussner's Lexicon. See also the interpretation of Gen. iv. 7, given supra, p. 173, and note on p. 220, supra. 
people's bad self, which had need to die. And so in the case of Christ: Christ knew no sin, but God made Him a sin-offering for mankind. As the goat symbolically, so Christ really, took upon Himself our fallen nature, and, crucifying it, passed into the heavens with the blood of the dead self in His hand (being Priest as well as Victim) to execute a covenant between God and our regenerate self: "That we might thus have grace given unto us to realize the righteousness of God by communion with Christ." (The thought is the same as that of Rom. viii. 3.)

This passage has been again and again explained by help of the idea of imputation - as though our sins were imputed to Christ, and Christ's righteousness imputed to us. It is a most unreal notion, and fails entirely to satisfy either the analogy of the sinoffering or the deep need of our heart.

For as to the analogy: The Jew, when he saw the victim on the altar bleeding and burning, never imagined that it was suffering the punishment he would otherwise have suffered. There is no trace of such an idea in the whole range of Jewish ritual; and if there was no such idea attaching to the symbol, then we may be very sure no such idea attaches to the reality to which the symbol pointed.

And as to the deep need of the human heart : it is not from the penalty of sin merely, but, oh! far more, from the sin itself that we sigh to be delivered. 
It is a poor theology that would dilute and explain away St. Paul's clear strong words by any doctrine of imputation. It is not to be thought righteous, but to be righteous, that we yearn. And this is what St.

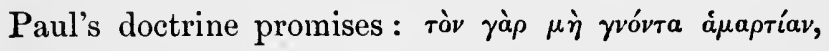

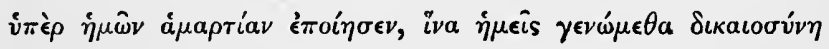

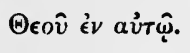

God forbid that we should soften away either the

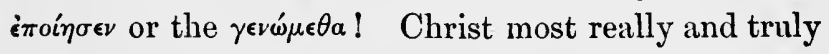
took our sinful nature, and regenerating it in the sacrament of His death, made it possible for us to be really and truly righteous.

What baptism once for all is to the individual, that the death of the Representative Man once for all is to the race. Though He had no bad self, yet He had identified Himself with us who had, and therefore in Him our bad self died sacramentally. His Atonement is to us not merely an acquittal from penalty, but a power of God unto salvation.

Galatians iii. 13, 14. This passage speaks of Christ becoming " a curse for us ;" and the thought in the Apostle's mind is again, donbtless, the sinoffering on the Day of Atonement, and specially the Scapegoat (Lev. xvi. 21); and therefore what has been said on the last passage ( 2 Cor. v. 21) may serve to explain this. The Apostle, in the ignominy 
of the Cross (attested by Deut. xxi. 23), sees an analogy to the scapegoat.

It is to be carefully noted that St. Paul, in quoting Deut. xxi. 23 ("He that is hanged is accursed of God "), omits the words "of God," as being inapplicable to the case of Christ. And yet Luther, and many after him, have dared to reinsert them. Luther's painful comment is as follows: "The Law steppeth forth and saith, Every sinner must die: therefore, O Christ, if thou wilt answer and become guilty and suffer punishment for sinners, Thou must also bear sin and malediction. Paul therefore doth very well allege this general sentence out of Moses, as concerning Christ, 'Every one that hangeth upon the tree is the accursed of God;' but Christ hath hanged upon the Tree, therefore Christ is the accursed of God."

Luther should have remembered Justin Martyr's protest against this misapplication of the text: It was not God who cursed the crucified, but the wicked Jews. (Dial c. Tryph, c. 96.)

In this passage of the Epistle to the Galatians a new

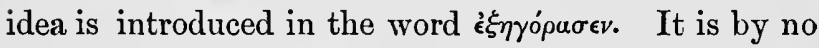

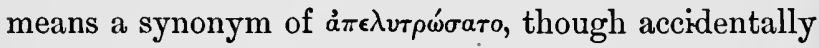
both may be rendered by the English word redeemed.

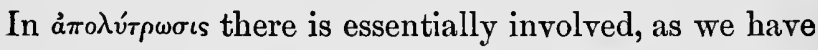
seen, the idea of a $\lambda$ v́rpov in the religious sense of the

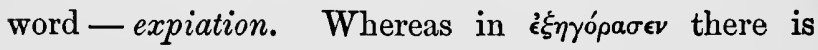


simply the idea of purchasing the deliverance of another at a great price. The word price (it need hardly be said), as applied to the sufferings of Christ, is a metaphor, and does not for one moment imply a transaction - one paying and another receiving. If a man rescue his friend from a burning house, and is badly hurt in so doing, his hurts are the price paid for his friend's deliverance, in the same metaphorical sense.

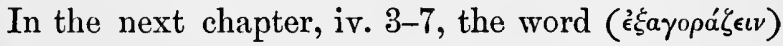
is repeated, with the additional idea that it was a bondage from which Christ at this great price redeemed us. That the price was not supposed to be paid to any one, is manifest ; for who was it that held us in bondage? - " the elements" - i. e., the elementary or literal rules - of a system of law, - a mere abstraction! 'This is the necessary servitude of one who is alienated from God. The death of Christ slew the bad self that made this coercion necessary, and made us capable of being intrusted with freedom, and so redeemed us from the bondage. Then the Apostle, as before, passes to the life-giving side of Christ's death. "And because ye are sons, God sent forth the Spirit of His Son ("the spirit and the life' of John vi. 63) into our hearts," making us conscious of our adoption.

The fourth important passage in which St. Paul 
sets forth his view of the redeeming work of Christ is in the Epistle to the Colossians i. 13-22, and ii. 11-15; for whatever allusions to it occur in the Epistle to the Ephesians are here repeated more fully.

The Epistle to the Colossians was written to Christians who were being seduced into a superstitious demonology. To them it was all-important to set forth Christ's work as a triumph over our spiritual enemies, over those "Principalities and Powers"

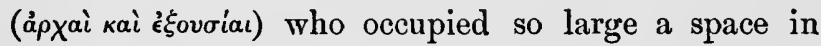
the theosophy of the Essenes. ${ }^{1}$

We found evident allusions to a mysterious conflict with these "powers of darkness" in our Lord's utterances. $^{2}$ Some light - not much can be expected but some light on this mysterious subject is supplied by this Epistle.

In the 13th verse we notice at once that it is not from our own evil self, but from "the power of darkness," that St. Paul speaks of our being delivered. And the word for "delivered" is not the word "redeemed" (for no גúrpov was here needed), but the word used in the Lord's prayer — "Deliver us from the Evil One."

Our English word "rescue" expresses it.

"God rescued us from the power of darkness, and translated us into the kingdom of His well-beloved

1 See Josephus, Bell. Jud. viii. 2-13.

2 See pp. 210, 211, supra. 
Son." The rescue needed no $\lambda \dot{\tau} \tau \rho o v$, but the translation into the kingdom of God's favor did need it; and therefore in connection with this second clause the Apostle adds, " in whom we have the redemption which His blood effected, the remission of our sins," reverting to the language of his Epistle to the Romans. He then declares Christ's absolute supremacy over all those intermediate spiritual beings, good or bad.

"For the Father was pleased that in Him the Fulness of the Godhead should dwell, purposing through Him to reconcile all things once more unto Himself, making peace by the blood of His Cross, - by Him, I say, whether they be things on earth or things in heaven " (so that nothing should be left in subjection to the Powers and Principalities). "And in this reconciliation, effected in his material body by means of death, you Gentiles have your share." (i. 19-22.)

Again, in the second chapter he asserts this absolute supremacy of Christ - temporarily infringed and compromised by the fall, which gave to the Powers and Principalities some dominion over man, but restored by the victory of the Cross.

"For in Christ all the Fulness of the Godhead dwells bodily (in His glorified Body); and in His Fulness ${ }^{1}$ ye are incorporated [owing no allegiance

1 The word "Fulness" should have been retained in our translation. It is a theological term, indicating the full complement of those Divine energies whereby God manifests Himself ; St. Paul asserts that this plenitude of Deity dwells in the one Clirist, and not in a plurality of mediators (or aons), as the Gnostics pretended. 
therefore, whatever, to any other Power], for $\mathrm{He}$ is supreme over all Principality and Power." (ii. 9, 10.)

Then the Apostle repeats the idea of Rom. vi., that Baptism is the application to the individual of the great sacrament which Christ's death was for the race. Our old self was buried with Christ that we might so rise with Him reinstated in God's favor. ${ }^{1}$

"God quickened you with Him, having forgiven us all our transgressions, having cancelled the hostile bond that was recorded against us in the decrees of the Law; and He (Christ) hath abrogated it by nailing it to the Cross ; divesting Himself ${ }^{2}$ (or ridding

1 Professor Lightfoot well brings out the force of all the aorist tenses of this passage: "St. Paul regards this change-from sin to righteousness, from bondage to freedom, from death to life - as summed up in one definite act of the past; potentially to all men in our Lord's Passion and Resurrection, actually to each individual man when he accepts Christ, is baptized into Christ." . . . " It is the definiteness, the absoluteness of this change, considered as a historical crisis, which forms the central idea of St. Paul's teaching, and which the aorist marks." - On Revision of New Testament, p. 85.

2 Our English translation ("having spoiled") makes better sense; but

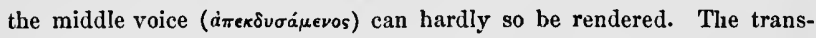
lation given in the text seems justified by the a and the $\dot{a} \pi \varepsilon \kappa \delta v \sigma a ́ m e v o c$ of iii. 9, where St. Paul speaks of our divesting ourselves of our corrupt nature. So here Christ may be said to have shaken off the hold which the powers of darkness had upon His mortal Body when His Spirit laid aside that mortal Body. The Peschito (always well worth consultiug) seems so to render it: - "Et, per expoliationem corporis sui, diffamavit principatus et potestates et confudit eos palam in semet ipso," - is the Latin rendering of the Syriac. 
Himself) of those Principalities and Powers (in divesting Himself of His mortal body), He exhibited them fearlessly in the triumphal procession of $\mathrm{His}$ Cross." (ii. 13-15.)

Thus in the Epistle to the Colossians we seem to have that aspect of Christ's death (as it regarded the power of the Evil One) which St. Panl's doctrine needed for its completion. Its effect on us directly, and on our relation to God, was what concerned the Apostle most in the great argument of his Epistle to the Romans; but surely (as we shall better understand perhaps within the Veil) its effect on the powers of evil was no less important to us. And if there was really in that dark hour a personal conflict and victory over the Tempter, maiming and lessening his power over mankind for all after time, is not a most helpful contribution made to the solution of the question, how the sufferings of the One could benefit the many? When David slew Goliath, were not all Israel the gainers? And if it had cost him life or limb, would not that suffering have been the price of their redemption?

We may now sum up St. Paul's teaching.

In the Epistle to the Romans we have the great lines of the doctrine.

We have two selves - a bad self $(\sigma a ́ p \xi)$ and a good 
self $(\pi \nu \in \hat{v} \mu a)$ : one needs to be killed, the other needs to be quickened.

Christ's Death effected the former, His Resurrection the latter.

How? By virtue of our mystical union with Him

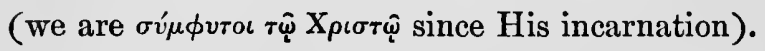

God therefore accepted His death as a security that

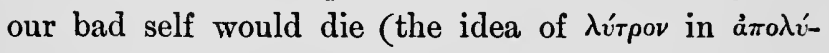
$\tau \rho \omega \sigma \iota s):$ and on this security admitted us freely into

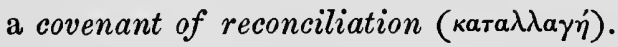

And "If when we were enemies we were thus reconciled to God by the death of His 'Son, much more, being reconciled, shall we be saved by His life." (v. 10.) The same mystical union that made His death our death, will make His life our life. (vi. 5.)

Thus freely, for our Sponsor's sake, we were pardoned or (in St. Paul's language) justified.

Being justified, we are - by the grace to which that justification admits us - sanctified.

And being sanctified we fulfil the pledge on the security of which we were justified.

In this train of thought there is one point, and that the point on which the whole rests, clearly needing further elucidation. How could the death of Christ effect the death of our bad self? The doctrine of the mystical union seems at first sight to fail here; for what died in Christ was a sinless self, what has to die in us is a sinful self. 
The passages above considered in 2 Corinthians $v$. and Galatians iii., seem to supply one answer, and that in Colossians another.

The first answer is: The body that Christ crucified was sinless it is true, but $\mathrm{He}$ made Himself a sin-

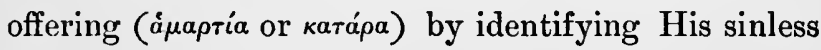
self with our sinful self.

The second answer is: Christ's death weakened forever the power of the Evil One, and so made it less difficult for us to crush him within us.

Or, to put St. Paul's doctrine yet more shortly, we may formulate it under three heads :-

1. A weakening of the Power of the Evil One.

2. Justification (or pardon) of man rendered possible by our having died to sin potentially in Christ's death.

3. Sanctification, by communion with Christ's life.

It will be seen how closely these three heads correspond with the three heads to which we reduced our Saviour's teaching in the Gospels.

Most beautifully and most completely is St. Paul's doctrine summed up in those three petitions of our Baptismal Service, in which we pray that what Christ accomplished once for all, as in a great sacrament for mankind, may be realized in the case of the child before us :-

Grant that the old Adam in this child may be so buried, that the new man may be raised up in him! 
Grant that all carnal affections may die in him, and that all things belonging to the Spirit may live and grow in him !

Grant that he may have power and strength to have victory, and to triumph against the devil, the world, and the flesh ! 


\section{CHAPTER IV.}

THE SOTERIOLOGY OF THE NEW TESTAMENT - CONTINUED.

v. THE TEACHING OF THE EPISTLE TO THE HEBREWS.

WE come now to the great anonymous Epistle of the New Testament, so unlike St. Paul's stlye in its diction that it can hardly have been penned by him ; but so thoroughly in harmony with St. Paul's habit of thought that it must have been written by one who was under his immediate influence. ${ }^{1}$

The Epistle seems to have been written when the signs of the time were unmistakably pointing to a speedy destruction of Jerusalem, and therefore of the temple-ritual. It was addressed, apparently, to the Jewish Christians who still clung to that ritual, and was intended to open their eyes to the great truth that Christ's incarnation, and death, and ascension, had entirely fulfilled the symbolic meaning of that ritual, and therefore, that which was symbolized having come, the symbol might safely cease.

1 It need hardly be observed that our Translators are responsible for the heading which it has in our English Bible; the Church Catholic affirms its inspiration and canonicity, but has never determined the question of its authorship. 
The method of the epistle is very clear: There is first a historical portion of five chapters, and then a mystical portion of five chapters.

By calling the first a " historical " portion, I mean that it rests on the plain facts of the Gospel narrative, - the fact that "God hath in these last days spoken unto us by His Son;" the fact that the scheme of salvation had been announced by Christ, and "confirmed unto us by them that heard Him" (ii. 3); the fact of His Incarnation and Death (ii. 14); the fact of the Agony which preceded that Death. (v. 7.)

I call the second a "mystical" portion (using the word not in its modern, but in its ancient sense), because it is addressed to those who, being already grounded in the facts of the Gospel, were competent to be initiated in those inner and spiritual meanings of the Old Testament which found their fulfilment in these facts (see vi. 1, where the word rendered "perfection" has in it the notion of initiation into what is mystical or spiritual).

Thus, in reference to our present purpose, we may expect to find in the earlier portion a setting forth of the atoning work of Christ, as accomplished in certain historic facts well known to the readers of the Epistle; and in the later portion we may expect to find a series of analogies, instituted between the grand accomplishment which that generation had 
witnessed, and those prefigurements whereby it had been foreshadowed to previous generations.

In the earlier portion the inspired writer is speaking directly of that which we are seeking to comprehend; in the latter portion he is speaking indirectly of it, by way of certain analogies.

With this preface let us open the Epistle.

In the first chapter the writer declares that the Jesus of whom he speaks was none other than that Son of God whose manifestation as the Messiah of Israel David had so confidently predicted.

In Him human nature was to be glorified; but, in order to this, the Son of God must first assume it in all lowliness; and, by entering into the closest possible fellowship with our sufferings, must qualify Himself to be our High Priest. Hence the appearance of Jesus in a state of humiliation; hence those sufferings bringing Him into brotherhood and sympathy with man, sympathizing with us even in our temptations; and hence, too, His Death. In this connection occurs the important 14 th verse of the second chapter: "Since the children of men are partakers of blood and flesh (involving mortality), $\mathrm{He}$ Himself also in like manner took part in the same; in order that by means of his death, He might destroy the ascendency of him who has the power of death, that is the Devil, and so might deliver those who, by dread of death, were all their lifetime sub- 
ject to bondage. For, need I remind you ? it is not angels that he is succoring but the seed of Abraham. Hence the moral necessity that $\mathrm{He}$ should be made altogether like unto $\mathrm{His}$ brethren, in order that $\mathrm{He}$ might become a merciful and faithful High Priest in our relations to God, to expiate ${ }^{1}$ the sins of the people. "For He Himself having been tempted, in that which $\mathrm{He}$ suffered, $\mathrm{He}$ is able to succor them that are tempted."

Now here two purposes of Christ's death (both introduced by "in order that") are brought into prominence.

The first purpose is the destruction of the Evil One's ascendency over mankind.

The second purpose is the expiation of mankind's sins.

We have seen that these two purposes were also intimated by our blessed Lord's utterances, and find equally distinct expression in St. Paul's Epistles.

1 Let us notice the forced use of the word i $\lambda$ á $\sigma \kappa \epsilon \sigma \theta \alpha$. How may this best be conveyed to an English reader. The word means "to propitiate," or "render propitious;" and the obvious phrase that a less profound theologian would have used would have been "to propitiate God." But neither here nor elsewhere does any inspired writer ever speak of Christ having propitiated God (in the heathen sense of the word). He wants to express in Greek the Hebrew idea that our sins are covered, that is, made as though they no longer existed, no longer separated between us and

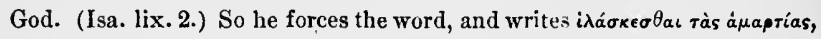
as though one was to say in English, "to propitiate our sins." Expiate is the word he wanted, had there been such a word in Greek. 
But here they are brought apparently into significant connection one with the other, and the words used in describing them are very remarkable.

First we notice the clearly intended paradox of the 14th verse, "by His death destroy the lord of death." Why should Christ's death have this effect? The 17 th verse supplies an answer: Because it expiated man's sin. The links of thought are clear.

Christ's death expiated our sin, and therefore deprived death of its sting (for " the sting of death is $\sin$ "), and therefore took away our fear of it, and therefore deprived the Evil One of that terrible ascendency which our fear of death had given him.

All this is clear.

But that phrase of the 17 th verse, on which it all rests, — "Christ's death expiated sin," — what in the reality of things does it mean?

This - we must lave felt it all through these pages - is the very question of questions, taking us into the heart of the mystery.

Does this passage throw any light upon it?

Perhaps it does: at all events the next verse begins with "for," which leads us to expect some explanation. The 17th verse says that it was essential to His priestly office of expiating our sins that He should be made like unto us. Why so? Left to ourselves we should not, I think, see the necessity. Did not the goat on the Day of Atonement expiate 
the sin of the people? And is not the goat of a nature totally different from ours, incapable of sympathy or communion with us?

Yes; and - for that very reason possibly - it made no real expiation: it only prefigured the real expiation. For real expiation there must be mystical union: without it, His dying unto sin would not have been our dying unto sin.

Thus, for two reasons, according to this Epistle, it was needful that he should pass through Death: (1) it made Him able to sympathize to the uttermost; He felt our sins as if they were His own, having in His own person felt the force of their temptation: And (2) mystical union was essential to expiation, and death to mystical union; - that He should by dying spiritualize - glorify (the word of St. John's Gospel) is a better word - the human nature which He had assumed. By passing through Death the last Adam became a quickening spirit (1 Cor. xv. 45 ), and so became qualified to enable mankind by communion with Himself to fulfil the pledge which He had given to God as their Sponsor ${ }^{1}$ on the Cross. Such seems to be the force of the very remarkable declaration in Heb. ii. 9, that Christ was glorified in order that His death might avail for all.

We now pass on to that wonderful passage in the fifth chapter, in which the inspired writer bids us 
gaze reverently on our High Priest in the very crisis and mystery of $\mathrm{His}$ high priestly office, under the shadow of Gethsemane :-

"Who in the days of His flesh - in that $\mathrm{He}$ offered up prayers and supplications with strong crying and tears to Him that was able to save Him from death, and was heard by reason of His reverent submission - though $\mathrm{He}$ was a Son, learned from the things that $\mathrm{He}$ suffered His obedience: and being made perfect, became the cause of eternal salvation to all who obey Him, being addressed by God (in the 110th Psalm) as High Priest after the order of Melchisedek." 1

The agony of that prayer was surely the measure of the conflict with temptation through which our Redeemer was passing; and the whole moment of this allusion to it is to show that by that conflict with temptation, $\mathrm{He}$ qualified Himself to be our High Priest, to enter into sympathy and communion with fallen man, and so succor him to the uttermost in crushing lis worse self. What then was the temptation with which the Tempter assailed His human soul? This passage seems to declare it: Even the same as in the wilderness, to ascend His throne without going through the valley of the

1 I have adopted Alford's translation. The Peschito puts a comma

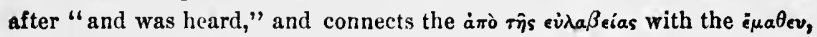
- "learned by His submission." 
shadow of death. By dying, therefore, $\mathrm{He}$ won His victory over the Tempter, as the second chapter told us.

Thus we have endeavored to view the actual work of Christ's death, as this inspired writer viewed it, as a necessary qualification for His. High-priesthood, in its twofold office-(1) as Sponsor for us to God; (2) as our Helper ever after in fulfilling what $\mathrm{He}$ had pledged us to.

We now proceed to the second portion of the Epistle (vi.-x.), in which we are to learn to recognize in all this the grand reality which the symbols of the Levitical sanctuary had foreshadowed.

This is done by a series of analogies. Those that bear on our subject are contained in the ninth and tenth chapters. (ix. 1-14.) As in the Levitical sanctuary the high-priest once in every year passed through the Veil, bearing the Blood of the Sin-offering in His hand, and made atonement for the people; so Christ once for all passed through the Veil of His Flesh, in dying, into Heaven, having by means of His own Blood obtained eternal redemption for us.

Only we must mark the difference (applying equally to the right of the Red Heifer):- those Levitical atonements only cancelled ceremonial defilement; whereas the blood of Christ, who through His eternal Spirit offered Himself without fault to 
God, will purify our conscience from dead works, and so enable us to serve the living God.

We have to notice here the same twofold effect of the work of Christ that we have found in almost every Scripture that we have examined : -

(1.) The effect as it regarded God, namely the ex-

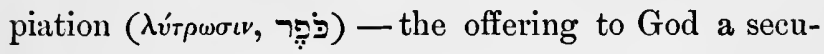
rity sufficient to enable $\mathrm{Him}$ to pardon sin.

(2.) The effect as it regarded man, namely the

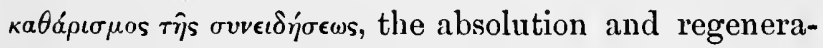
tion of the better self, that should enable him to renounce his dead works, and by serving God from the heart, make good the pledge which Christ had given.

ix. 15-28. - As the Old Covenant was inaugurated with blood of sacrifice - Moses sprinkling the book and all the people with it, saying, "This is the blood of the covenant," - and as subsequently the sanctuary and all it contained were sprinkled with blood, and one might say generally that under the Mosaic Law there is no purification or remission without shedding of blood, ${ }^{1}-s o$ it was necessary that the Kingdom of Heaven (Christ's Church) should be inaugurated by some more effectual sacrifice; - what sufficed for those merely typical things, not sufficing for the grand reality which they prefigured.

1 The second clause of the verse (Heb. ix. 22) is often quoted as if it were a universal axiom ; whereas, surely, the words "under the Law," limit both clauses. (See note to p. 248.) 
The sanctuary where Christ is now performing His high-priestly office for us is Heaven; and the more effectual sacrifice, wherewith $\mathrm{He}$ inaugurated His high-priestly office, was His sacrifice once for all upon the Cross. That sacrifice had no need to be repeated annually, for it was effectual for the cancelling of $\sin$

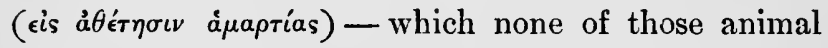
sacrifices could be. For as it is appointed unto men once to die, and after that judgment ; so Christ, having been once offered to bear the sins of many, shall appear a second time, without any sin-offering, to them who be waiting for Him, unto salvation.

In this passage the prominent idea is the analogy of the two covenants. The sprinkling with sacrificial blood at the inauguration of the Mosaic Covenant was intended to prefigure the great truth, that God could not take fallen man into favor without a purification of man's nature, such as the death of Christ alone could effect. The writer's object in this portion of his epistle being not to set forth the work that Christ had done in its own nature, but rather to show how it stood to the Mosaic sacrifices in the relation of substance to type, fulfilling and therefore superseding them, he is careful to speak of it in sacrificial language - Christ was " offered" ( $\pi \rho \circ \sigma \epsilon \nu \in \chi \theta \epsilon i s)$ " to bear sin"

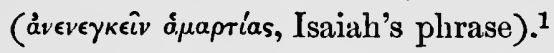

In the tenth chapter, we have a contrast rather

1 The true meaning of this phrase will be considered infra, p. 252. 
than an analogy. Those oft-repeated animal sacrifices could never really expiate sin, but were only outward and visible emblems, pointing onwards to a transcendent spiritual act, whereby, from the very first, God had purposed to bring about the expiation of man's sin. Of what kind this real expiation must needs be, the Psalmist had revealed, speaking in the person of the Messiah. The Levitical sacrifices ${ }^{1}$ are declared to be rejected; and what does the Messiah reveal as to the nature of His own great act which is to supersede them once for all? "A body hast thou prepared Me," 2 - this first, His incarnation, as essential for what is to follow; - and then in this Body the great act of obedience whereby God willed and designed to effect the expiation of man's sin. What that divine will and design was, we are told in the next verse: it was a process of sanctification (that is his word, and it is important); and the process was the death of Christ, - we were to be sanctified by means of the sacrifice of that Body which Christ had assumed.

1 All the four great classes are enumerated: $\theta v \sigma i a$, the peace-offerings;

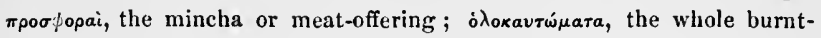

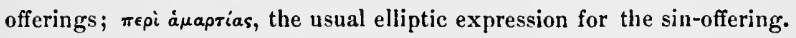

2 It is quite immaterial whether or not the LXX. version correctly represents the sense of the Hebrew. It was the version which the writer and his readers used; and he found in it an expression whicl served to set

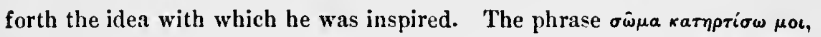
however it found its way into the Greek Psalter, became when appropriated by the writer of this Epistle, an inspired utterance. 
In the 19th and three following verses we may perhaps discern the thought that was in his mind when he spoke of the death of Christ being necessary to this sanctification. For that 19th verse begins, "Having therefore boldness to enter into God's presence," ... clearly meaning that Christ's death has given us this boldness. How? By opening the way to us. Death up till then had been a dark passage leading we knew not whither. Christ traversed it, and visibly issued into light and life. What before had been at best a faint and flickering hope, burst into a clear flame of faith in the light of His resurrection. And without His death there would have been no resurrection.

So that in this way, if His death had done no more, it would have given us a motive for sanctification stronger than any we had known before. But it did much more. This way that $\mathrm{He}$ opened is called a new and living way. Let us mark that word "living." It seems to mean, what so many other Scriptures have suggested, that the life or soul that was in the blood of Jesus, that is, the human life or soul which $\mathrm{He}$ had assumed in His incarnation, became from that moment available as a vital principle for all who enter into communion with Him. This is a mystery; but Scripture after Scripture seems to reveal it to us: that the blood which He poured forth in death - meaning of course the life or soul that was in the 
blood - became from that day onwards a strengthening, purifying, regenerating power, mingling with the life of all who are in communion with Him. All those figurative phrases about our being cleansed, or washed, or sprinkled by His blood, seem to have this for their real meaning. Surely this is the meaning of what he says in the $22 \mathrm{~d}$ verse: As our bodies in Baptism are washed with pure water, so when we enter into communion with Christ we have our hearts sprinkled from an evil conscience: surely he means that we become conscious of a process of sanctification going on within us, due entirely to that pouring forth of the soul of Christ in Death, that it might be the life of the world.

And it was to this great result of Christ's death that all those sprinklings of sacrificial blood under the Law had pointed. This most effectual provision for the sanctification of mankind, made by the death of Christ, it was, that rendered. it possible for God, without any lowering of His standard of holiness, to remit and pardon the sin of man. In a word, therefore, Christ's death expiated sin.

We may now sum up the teaching of the Epistle to the Hebrews. And no words will serve our purpose better than those admirable words of Bishop Butler.

"The doctrine of this Epistle plainly is, that the legal sacrifices were allusions to the great and final 
atonement to be made by the blood of Christ; and not that this was an allusion to those. The priesthood of Christ, and the tabernacle in the mount, were the originals : of the former of which the Levitical priesthood was a type; and of the latter the tabernacle made by Moses was a copy." 1

In the earlier chapters (as we have seen) we have, without the veil of sacrificial language, a setting forth of some of the great purposes for which Christ died :-

1. It was needful that Christ in His human nature should be tried and tempted to the uttermost, in order that by resisting that temptation to the uttermost, even unto death, He might destroy the Tempter's ascendency over the children of men. (ii. 14.)

2. It was needful that $\mathrm{He}$ should enter into fellowship with all our sufferings and trials even unto death, in order to qualify Himself to sympathize with us and succor us to the uttermost, and so under-

1 Analogy, pt. ii. ch. 5. Bishop Pearson (On the Creed, art. iv.) seeme, in some passages, to invert the meaning of the Fistle to the Hebrews, and to speak as if the Mosaic Sacrifices were the originals on which Christ's sacrifice was modelled: "Because the sacrifices of old were to be slain, and generally 'without shedding of blood there is no remission;' therefore if $\mathrm{He}$ will offer sacrifice for sin, $\mathrm{He}$ must of necessity die, and so 'make His soul an offering for sin.' If Christ be our Passover, He must be sacrificed for us." How far more profound is Bishop Butler's teaching! That without shedding of blood there is remission is no general axiom : but because in the eternal counsels the Death of Christ was the predestined atonement for man's sin, therefore (in order to prefigure this) there was under the law no remission without a shedding of blood. 
take to sanctify us as our High Priest and Mediator. (v. 7-9.)

3. His Death, affording as it did these securities for our regeneration, rendered it possible for God to absolve us from our past sin, and take us into a new; Covenant with Himself. His death was therefore, in the reality of things, all that is meant by an Expiation; and was the grand original of which all those Levitical sacrifices were faint imitations.

How incomplete would have been our conception of Christ's redeeming work on earth if this Epistle had never been written! We hardly remember sufficiently perhaps that to it, and it alone, we are indebted for this aspect of Christ's Passion, as qualifying Him to be the Intercessor, Mediator, and High Priest of him whose nature for this purpose $\mathrm{He}$ had assumed! Surely it was the Epistle to the Hebrews more than any other Scripture that inspired that prayer of our Litany: "By thine agony and bloody sweat, by Thy Cross and Passion, by Thy precious Death and Burial, by Thy glorious Resurrection and Ascension, - Good Lord, deliver us."

\section{THE TEACHING OF ST. PETER.}

A special interest attaches to St. Peter's teaching on this subject, because of his direct application of the great prophecy of Isaiah liii. to the Death of Christ. And on the interpretation of Isaiah's lan- 
guage, which St. Peter is supposed to sanction, rests almost exclusively the theory of the Pona vicaria, the theory that Christ bore the penalty of our sins, and so saved us from bearing it.

We have found no ground for this theory in our Lord's own teaching, nor in St. Paul's teaching, nor in that of the Epistle to the Hebrews, nor shall we in that of St. John. However, if it really be implied in this Epistle of St. Peter, and in the 53d of Isaiah as here interpreted, then it has scriptural authority, and must be accepted.

With all care, and without prepossession, let us examine St. Peter's allusions to our Lord's Death. It is at the close of the second chapter that the citation from Isaiah occurs. But we must first consider the equally important passage in the first chapter.

i. 18-23. St. Peter is enforcing the duty of holiness. His first ground is God's holiness. The second ground is the awe with which we should regard Him, remembering that $\mathrm{He}$ is not only our Judge, but our Father. This thought, that God has made us His children - hath regenerated us (it is St. Peter's favorite word, occurring twice in this chapter) leads him to remind his readers of the way in which this regeneration had been effected.

“ Ye were redeemed ('ं $\lambda v \tau \rho \omega \dot{\theta} \theta \tau \epsilon)$ from your hereditary sinfulness, not with perishable silver and gold (as from a human slave-master), but with blood (as 
from a spiritual bondage), with precious blood, as of a lamb blameless and spotless, even of Christ." St. Peter here is closely following Christ, who said the

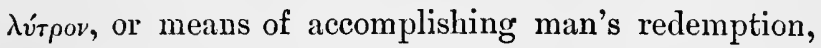
was His life or soul $\left(\psi v \chi \eta^{\prime}\right)$, or in Hebrew idiom blood. (See pp. 206, 246, 271.)

But how did St. Peter explain to himself the efficacy of this blood (or soul in English idiom) which Christ poured forth like a Paschal lamb in death? $\mathrm{He}$ clearly attributes to it a sanctifying efficacy: "Having sanctified or purified your souls in your obedience to the Gospel, leading on to unfeigned love one towards another, love one another from the heart earnestly (and this is now possible, for) ye have been regenerated" (here seems to be the efficacy of the blood) " not of corruptible, but of incorruptible seed" (Christ's $\psi v \chi \eta^{\prime}$, poured forth for this purpose), "by means of the living and undying Word of God" (by means of that Divine nature that was united to the Human Soul so poured forth).

The points to be noted here are : (1.) that it is from sin, not from the penalty of sin, that Christ's

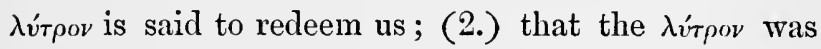
efficacious, not because it was of the nature of a payment to any one, but because it had in itself a sanctifying virtue, being none other than the regenerating life-blood or vitality of Christ.

So far, then, St. Peter's teaching is in perfect accord 
with the teaching that we have discerued in previous Scriptures.

Now let us consider the important passage in the second chapter.

ii. 21-25. The Apostle is now enforcing the duty of patient endurance of undeserved suffering. And he holds up to us Christ's patience, when He suffered far greater suffering, for well-doing infinitely transcending any well-doing of ours.

"For Christ also suffered for our sake, leaving an example that we should follow in His footsteps; who did no sin, nor yet was guile found in His mouth; who, when reviled, reviled not again; when suffering, threatened not; but committed all to Him who judgeth righteously;" so far His patience is set forth, and now the well-doing for which he suffered all this : "Who Himself carried up our sins in His body to the tree, in order that we might die to our sins and live to righteousness; by whose stripes ye were healed."

Such is the passage translated as closely as possi-

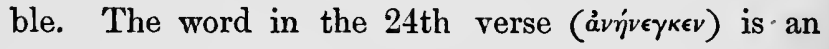
ordinary word for offering a sacrifice. But as it is here followed by the accusative of motion, "up to the tree," we are obliged to use the English word "carried," the idea being that of the priest carrying the victim up the slope that led to the Brazen Altar in the Temple. It is the word used for Abraham offer- 
ing Isaac in James ii. 21. And again in the same sense, in Heb. vii. 27, xiii. 15. And in this same chapter (verse 5) St. Peter had just used it for offering up spiritual sacrifices. It never means bearing in the sense of enduring. If St. Peter had meant to say that Christ bore the punishment of our sins, he would have used the obvious word i $\pi \circ \phi$ ć $^{\prime} \epsilon$ (v (which occurs only five verses previously): or he would

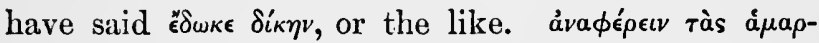
rias expresses a totally different idea. The idea is clearly the idea of carrying up our sins to His cross, and crucifying them there. It is the same idea as that of St. Paul in Rom. vi. 6: "Our old man is crucified with Him ;" and again, Gal. ii. 20, v. 24 ; Col. ii. 14. Indeed, that this was St. Peter's meaning, he himself declares to us, in the words that follow: " that we, being dead to our sins, should live to righteousness." And, again, he makes it clear by those other words, "by whose stripes ye were healed." If he had meant, "by whose stripes ye were saved from stripes," he would have said so. But that was not his meaning; he was not thinking of punishment at all; his idea is the far more scriptural idea, that we were redeemed from the sin itself, the disease of $\sin$, by the death of Christ: "by whose stripes" - the revilings and sufferings he had just mentioned - "ye were healed."

We may notice also incidentally (as confirmation 
of what Bishop Butler says so well about Christ's sacrifice being the original, and all those other sacrifices mere copies) that St. Peter speaks (in i. 20) of Christ's sacrifice having been "foreordained before the foundation of the world," - no afterthought consequent on the Fall; but part of an etermal purpose for the development of the rational free agent whom He had created.

But some advocate of the penal theory may say, "How about the original passage of Isaiah which St. Peter is quoting?" And the answer is, that what has been here said about the Greek word ảvaф́' $\rho \epsilon \nu$ applies to the Hebrew word בָָָ (nasa); the literal meaning is to lift up (as the feet, the hands, the voice, etc.); then to carry away; thus the goat carried away the people's sin to Azazel (to "separation," as some understand it). Hence, in Lev. x. 17, the phrase that the priests " bore, or carried away (nasa), the iniquity of the congregation," is used as an equivalent of " making atonement for it." And in several places it thus comes to mean "forgive" 1 (as Gen. 1. 17 ; Exod. x. 17, xxxiv. 7 ; Num. xiv. 19 ; Isa. ii. 9, xxxiii. 24). Therefore, in Isaiah liii. 11, the Hebrew word, as well as its Greek equivalent, means to

1 This same word $\mathrm{Nim}_{\mathrm{T}}$ is used in Ex. xxviii. 38, where Aaron is said to bear the iniquity of the holy things on his forehead; where the idea of penalty is simply impossible. It is true that in Ezek. xviii. the word is used frequently for bearing a penalty. But this is not the sacrificial sense of the word. See p. 178, note 2, supra. 
"atone for" or obtain "pardon for :" and the Christian interpretation of it (adhering closely to the radical meaning of both words), is that Christ carried up our sinful self to His Cross, and there crucified it in His own Person. ${ }^{1}$ (See p. 179, supra.)

Thus, to close these remarks, so far from discountenancing the view of Christ's Atonement, which we have learned from the other Scriptures, this passage of St. Peter's Epistle confirms it.

Thus from St. Peter (1) we obtain a striking confirmation of the interpretation given (on pp. 197-204,

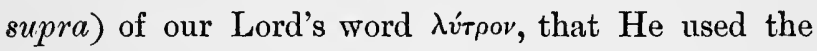
word in its sacrificial, not in its forensic, sense: the sense in which the Israelites were redeemed by the Paschal Lamb; not the sense in which we speak of a captive debtor being redeemed from prison.

(2.) Next we observe in both these passages a close connection between the blood-shedding of Christ and our regeneration, implying that the soul that was in that blood was the new vital principle which, infused into us, regenerated us.

In other words, the Blood of Christ, according to St. Peter's teaching, had a twofold efficacy.

(1.) It was a $\lambda$ úroov obtaining for us restoration to God's favor.

1 It is no slight argument in favor of this interpretation of $N_{T} \underbrace{}_{T}$ (remoring, not enduring) that it justifies at once St. Matthew's quotation of Isaiah liii. 4. (Matt. viii. 17.) 
(2.) It was a regenerating principle passing into our very life; and the two are manifestly connected very closely in his mind.

To these two heads of doctrine we may add a third, completing the parallelism between his teaching and that of the other Apostles: From the concluding verses of the third chapter we learn that he too believed that one result of Christ's death was the defeat and final subjection of the powers of evil. His expressions are almost exactly similar to St. Paul's in the Epistle to the Colossians - "Angels and authorities and powers being made subject unto Him."

\section{THE TEACHING OF ST. JOHN.}

We will endeavor to gather St. John's doctrine of the Atonement from his Epistle. The allusions to it in the Gospel are mostly our Lord's own words, and as such have been considered. So in the Apocalypse he is not speaking in his own person, the allusions occurring in the Angelic Hymns, and being too highly charged with poetry to be doctrinally analyzed. Nor is there any idea connected with the Atonement suggested in the Apocalypse that may not be found in the Epistle. To the Epistle, then, we turn.

At the close of the first chapter, we find the following words: "If we confess our sins, $\mathrm{He}$ (God) is faithful and just to forgive us our sins and cleanse us from all unrighteousness." Faithful and just! 
They are not exactly the words that one fresh from some of our modern divinity would have used. As some modern divines have interpreted St. Paul's "just and justifying" (Rom. iii. 26) into " just and yet justifying," so some might also wish to change St. John's "faithful and just to forgive," into " merciful and willing so far to surrender His justice as to forgive."

But let the Apostles rather than modern divines be our teachers. Here are the inspired words, "faithful and just to forgive." They imply a Covenant to forgive ; and was not this exactly our Lord's own teaching in the institution of the Eucharist - "the blood of the new Covenant?" And there are words in our Baptismal Service quite answering to St. John's "faithful and just" — "which promise $\mathrm{He}$ for His part will most surely keep and perform."

The Atonement, then, according to St. John's view, was a Covenant: On God's part forgiveness, and on our part what? A Socinus or Crellius might answer, "Is it not plain? "if we confess' - confession implying of course repentance." But as Atlanasius pointed out long ago, repentance could never suffice, sin being not merely an act of disobedience requiring pardon, but also a disease needing cure. And St. John clearly recognizes this: "God is faithful and just to forgive us our sins, and to cleanse us from all unrighteousness." 
But this cleansing seems to be on God's part, and we are seeking man's part in the covenant. St. John will himself meet this difficulty. He had spoken of this cleansing a few verses before: "The blood of Jesus Christ His Son cleanseth us from all sin." It is Christ's doing then? Yes, but Christ assumed Human Nature in order to do it; became a man among men; did it therefore, as on man's part, as our part of the Covenant, becoming man's Sponsor (or, in the language of the Epistle to the Hebrews, man's High Priest) in things pertaining to God. How does this notion of Christ's sponsorship or HighPriesthood appear in St. John's teaching? In the next chapter (ii. 2) we find him teaching us that Jesus Christ is an expiation of our sins - a clearly sacrificial sacerdotal word.

Now what does St. John mean by Christ being an expiation? This brings us into the very heart of the mystery. What do we mean by expiation? We mean a something that renders forgiveness possible without any lowering of the moral standard.

But is this St. John's idea of expiation as applied to the work of Christ?

We bring together at once the verse that speaks of Christ being an expiation, and the verse that speaks of His blood cleansing us from all sin. Clearly if Christ on our part covenants that we shall be cleansed, God on His part may forgive without any 
risk of lowering the standard of holiness. But how was Christ able to give security for this cleansing? St. John answers "by His blood," His death provided for this cleansing in a way that nothing else could.

It need hardly be repeated that by blood here, and all through these Scriptures, the life that is in the blood is meant. The life (that is, the human soul) of our Lord abides eternally and is communicable to man. While that life (in Hebrew phrase) flowed in the veins of Jesus it was incommunicable to man. The "whole tenor of our Lord's discourses in St. John's Gospel seems to teach us that His Death was necessary in order that it might become communicable to man. He would give His flesh and blood to be the life of the world. ${ }^{1}$

And St. John takes up this teaching at the very opening of this Epistle. The Second Person of the Trinity, manifested visibly, tangibly, awhile, and then withdrawn, $\mathrm{He}$ is this Life, this Divine Life, now (by virtue of the hypostatic union) communicable to man, with whom the Christian may hold communion. Such seems to be the intention of the first three verses. Christ's blood-shedding then being necessary in order to the communication of this Divine regenerating Life, that blood-shedding was the required security given on our behalf ( $\dot{v} \pi \dot{\epsilon} \rho \dot{\eta} \mu \hat{\omega} v$ ), to render possible the pardon and restoration to favor, which was God's part in this New Covenant.

1 See pp. 205, 271. 
And therefore St. John calls this blood-shedding

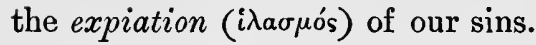

We observe, in the third chapter, that St. John uses the same word that St. Peter had used to express this vital principle thus communicated to man : he calls it seed ( $\sigma \pi \epsilon^{\epsilon} \rho \mu \alpha$, iii. 9) because it regenerates.

That this communication of a new life to us (rendering a new covenant between God and man possi-

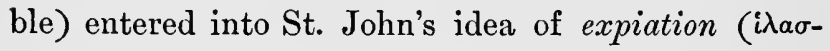
$\mu$ ós), seems to be further proved by a careful comparison of the 9th and 10th verses of the fourth chapter. In one verse St. John says the purpose of Christ's mission was that we might live (have this higher life put into us) through Him; in the other verse he says the purpose of Christ's mission was that He might be an expiation of our sins ; implying that the two purposes were to some extent coincident.

In the Apocalypse we have repeatedly the expres-

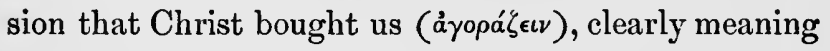
that Christ having laid down His life for us, the redeemed belong to Him as though they had been purchased by that sacrifice. (Rev. v. 9 ; xiv. 3, 4.)

Thus, to conclude, from St. John's teaching also we obtain these two moments of doctrine :-

(1.) That Christ's death infused a new life into the world.

(2.) That it was also an expiation, rendering possible a new covenant of forgiveness, with security 


\section{THE SOTERIOLOGY OF THE BIBLE. 261}

that the standard of holiness would not be thereby lowered.

In another brief passage St. John recognizes a third purpose of Christ's manifestation - "that $\mathrm{He}$ might destroy the works of the devil."

So the same three points of doctrine that we drew from the teaching of the other Apostles may claim the authority of the Disciple also whom Jesus loved. 


\section{CHAPTER V.}

THE SOTERIOLOGY OF THE BIBLE - CONCLUDED.

WE will now endeavor to sum up the Soteriology of Scripture in a few general propositions.

I. First, as to the necessity of such a scheme of salvation. Scripture clearly sets forth the doctrine of the Fall: "By one man sin entered into the world, and death by sin; and so death passed upon all, for that all sinned." (Rom. v. 12.) By "death" is here meant not only natural death, but also that of which natural death is the outward symptom, - "alienation from the life of God" (Eph. iv. 18), and bondage to the lower nature and to the Evil One. (2 Pet. ii. 19; Heb. ii. 15.) Such were the consequences of the Fall, and from these consequences of the Fall (excepting only the natural death) the love of the Father moved Him to deliver us. For Scripture is ever careful to teach us that we owe it to the love of the Father. (See John iii. 16 ; 2 Cor. v. 19; Tit. iii. $4 ; 1$ John iv. 9, 10.) But whence the necessity of so costly a sacrifice? Could not God, by a single word of His free grace, have pardoned man? The teaching of Scripture is clear; the Parable of the 
Unmerciful Servant shows how vain would have been such mere remission of penalty without redemption from $\sin$. It was not from "the wages of sin" merely, but from sin itself, that God would deliver us, - "from all iniquity" (Tit. ii. 14); "from our" vain conversation" (1 Pet. i. 18) ; "from the power of darkness." (Col. i. 14.) Therefore mere pardon would not suffice; it would be only a lowering of the standard of righteousness, unless there were also a redemption from evil.

But why not rescue us from evil, from this thraldom to the Evil One, by a high-handed act of sovereign power? "By strength of hand" God delivered His people from Egypt, - why not even so from bondage to the Evil One, without the costly sacrifice?

Again, Scripture is clear. It was a being of freewill, one who could render Him the service of a free heart, that God had originally created, and the inference is plain ; and God would not compromise the free-will of man in the process of deliverance. He would not " enforce his will," in the language of our Articles of 1552. He would call us friends, not slaves. (John xv. 15.) He designed for us "the glorious liberty of children of God." (Rom. viii. 21.) Therefore the process of restoration must be such as would indeed set us free to choose the good, and strengthen us to resist the evil, but for the rest leave 
us free "to work out our own salvation" (Phil. ii. 12); "As though God did beseech you by us, we pray you in Christ's stead be ye reconciled to God." (2 Cor. v. 20.) If man's evil will had been simply crusled, his freedom and his moral responsibility would have been destroyed, and the design of his creation frustrated. How, then, should God deal with him?

II. 'This leads us to the process whereby our salvation was accomplished. Scripture, from first to last, reveals to us that it is by way of Covenant that God deals with mankind. Again and again God had taken man into Covenant witl Himself, and again and again man had forfeited the Covenant. And even so in this final scheme of restoration, it is by a "new Covenant." (Matt. xxvi. 28 ; Heb. viii. 6, xii. 24.) No doctrine of the Atonement can be considered scriptural that loses sight of the idea that it is a Covenant.

And very clearly Scripture unfolds to us the two terms of the Covenant, - "This is the Covenant that I will make with them after those days, saith the Lord; I will put my laws into their hearts, and in their minds will I write them," - this on one side, - God requires that the law of holiness shall be impressed on man's heart; "Then said He, And their sins and iniquities will I remember no more;" this on the other side, an act of amnesty, or absolution, 
on God's part. Indeed, the word Covenant necessarily involves the idea of an engagement on both sides. God could not forgive sin, unless the law of holiness were first satisfied.

III. But what is meant by satisfaction when it is spoken of as a condition of man's restoration to God's favor? The word is not found in Scripture, but the idea is repeatedly. What, then, is the scriptural idea?

And, first, is it the discharge of a debt due to God? This is the basis of the whole of the Anselmic theory, - that man's sin had robbed God of the honor due unto His name, and that this must be repaid. But we never once met with this idea in our analysis of the teaching of Scripture; nor, when we come to think of it, is it consistent with Scripture. For Anselm's theory makes God's need of compensation the motive of the Atonement; whereas Holy Scripture clearly reveals to us that God's love of man was the motive. Satisfaction, then, does not mean the discharge of a debt.

But, secondly, does it mean the payment of a penalty? This is the idea which underlies the Calvinistic theory of the Atonement.

But have we found this idea expressed or implied in any of those Scriptures that we have been examining? The only passage that has any appearance of this meaning is the fourth and fifth verses of the $53 \mathrm{~d}$ 
of Isaiah. And we have seen how far more in harmony with the teaching of the New Testament, and with the original Hebrew of the passage, is that other interpretation of the verse, that the Messial entered into fellowship with all our sufferings, healing the disease of the soul even as He healed the diseases of the body, - in accord with St. Matthew's application of the fourth verse (Matt. viii. 17), and St. Peter's of the fifth. (1 Pet. ii. 24.) That Christ (as a Priest ${ }^{1}$ and as a Sacrifice ${ }^{2}$ ) " bore our sins" is indeed repeatedly affirmed; but that " $\mathrm{He}$ bore the punishment of our sins," never.

Nor indeed can it be maintained that by Himself bearing the penalty $\mathrm{He}$ saved us from bearing it. For what was sin's penalty? Death either temporal or eternal. If temporal, then $\mathrm{He}$ did not save us from it, for we still die in this sense; if eternal, then assuredly Christ never so died. His satisfaction, then, is not to be understood in a penal sense.

But, thirdly, is the satisfaction to be explained by the theory of imputed righteousness? If this mean that Christ's perfect righteousness is so imputed to us that God accepts us as holy, while in point of fact we remain unholy - an idea that some ill-advised expressions of Luther seem to countenance - then not only the healthy conscience, but Scripture also, re-

1 Compare Exod. xxviii. 38 ; Num. xviii. 1.

2 Lev. x. 17 ; xvi. 22. See also pp. 178, note, 254. 
jects the doctrine. For what is it, according to the Epistles to the Galatians and Romans, that is counted unto man for righteousness? It is faith. (Rom. iv. 5.) And what is St. Paul's idea of saving faith? "The just shall live by faith;" it is a new life in the soul; it is a new energy which we derive from communion with Christ. (See Gal. v. 6, compared with the parallel passage 2 Cor. v. 17.) The truth that "without holiness no man shall see God" is in no sort superseded.

What, then, lastly, is the scriptural idea of the satisfaction, without which God could not pardon or restore man to His favor? As we have seen already, it is that dying unto sin which the law of holiness required.

The Epistle to the Hebrews works out this idea.

IV. Could man, could any human priesthood, thus satisfy the law of holiness? The Epistle to the Hebrews plainly declares that it was impossible. And yet it must be done on man's part, for it is man's side of the Covenant. The solution was the death of the God-man. But why the death? For three reasons:-

1. That the dying unto sin, the death of the old Adam, might be perfect.

2. That the Evil One might be vanquished in his own realm of death.

3. That the life or soul so poured forth might become communicable to us. 
All this (need it be said?) is most mysterious ; but such seems to be the teaching of Holy Scripture, and especially that of the Epistle to the Hebrews.

To that Epistle we turn; and what have we there presented to us? We behold the Eternal Son of God, made for a brief while lower than the angels, taking upon Him our nàture, capable of temptation, capable of death, that He might, as our High Priest, be the "Mediator" or "Surety" of a new Covenant

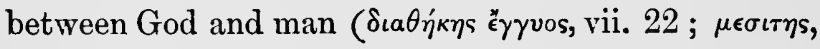
viii. 6), and so expiate or "make reconciliation for"

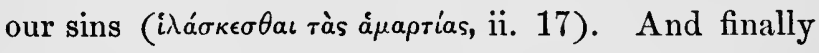
we behold Him passing throngh the Veil of death even unto the Mercy-Seat of the Divine Presence, there to claim for us the Pardon, with the Security in His hand which rendered that pardon possible (ix. 11, 12), - the blood of the Cross, whereon the death unto sin had been accomplished for the whole race.

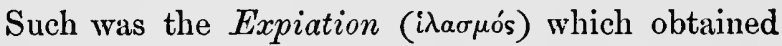
our pardon. And what to us was the result? The

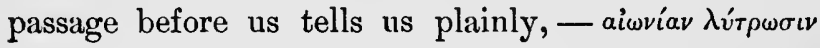

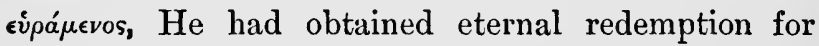
mankind, He had made provision once and forever for mankind's pardon, and redemption from the power of sin.

And how were we redeemed from the power of $\sin ?$

In two ways: (1.) The power of the Evil One 
over us was lessened. Evil One was increased.

(1.) How did Christ lessen the power which sin had over us? 'If the common enemy of mankind were defeated and crippled by what Christ did, then his power over men was lessened forever after. And this is the teaching of St. John's Gospel: "Now shall the prince of this world be cast out" (xii. 31) ; "The prince of this world cometh, and hath nothing in Me" (xiv. 31); "The prince of this world is judged" (xvi. 11); "Be of good cheer, I have overcome the world" (33). And this is equally the teaching of the second and fifth chapters of Hebrews. There we have revealed to us the mystery of the Agony. We behold Christ entering into the closest fellowship with our infirmities, feeling all our sin as if it were His own, agonizing with temptation, yea with the Tempter himself, depending entirely in this conflict on the same source of strength that we have to depend on, - prayer (such was the mystery of His

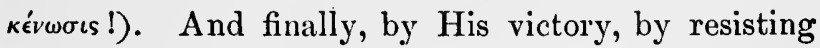
the Tempter even unto death, and through death cleaving a way to life, we are taught that $\mathrm{He}$ destroyed the ascendency which the Tempter had over mankind, thereby delivering those whom heretofore the king of terrors had held in thraldom. (ii. 14, 15.) Thus, to one who believes in the personality of the Evil One half the mystery of redemption is solved. 
(2.) But the other half remains. Not only did Christ lessen the power of evil, but He strengthened us by His death. How? St. Paul (as we have seen) explains our regeneration by the idea of our rising again with and in Christ; but this is hard to grasp. St. John's Epistle and Apocalypse, as also the Epistle to the Hebrews, explain it by saying that we are washed, purged, cleansed, by His blood; but this is metaphorical. Let us turn to St. John's Gospel, and we shall find the sacramental efficacy of Christ's death for our regeneration unfolded in a way that we can more readily assimilate.

The more we meditate on our Lord's discourses there recorded, the more it grows in clearness that our Lord regarded His dissolution - the separation of His flesh and blood, that is of His body and soul (for blood here as ever stands for the life that is in the blood) - as needful in order that the latter (the life that was in the blood) might pass into us. The life that was in the incarnate Christ could not be made communicable to us until it had been glorified," that is, spiritualized by passing through the process of death. "Except a corn of wheat fall into the ground and die, it abideth alone; but if it die, it bringeth forth much fruit" (xii. 24); "For their sakes I sanctify myself" (devote myself to death), "that they also might be sanctified." (xvii. 19.) And again, what but this is the thought whereby $\mathrm{He}$ 
comforts His Apostles on the eve of His death?" the whole burden of that discourse is that $\mathrm{He}$ must die in order that $\mathrm{He}$ may return to them far more effectually. He had been with them, He would be in them. (xiv. 17.) So St. Paul tells us that Christ by dying " became a life-giving spirit." (1 Cor. xv.)

Remembering, then, that the blood means the life that is in the blocd, ${ }^{1}$ we begin to see the real meaning of those Scriptures that speak, in varying phrase, of our being regenerated by the blood of Christ; of the blood of Christ (the life of Christ infused into us) "purging our conscience from dead works to serve the living God:" St. Paul ventured to say, "Not I, but Christ liveth in me." (Gal. ii. 20.) And even so had Christ said that he gave his flesh for the life of the world; and that unless we drink His blood, we have no life in us. (John vi. 51, 53.)

Thus, then, did Christ by dying strengthen us to resist evil. And we have seen before, how, by His

1 In our Hymns and Devotions we do well to retain the Hebraism, so hallowed in its associations; but when we are concerned with Doctrine we should substitute for the word "blood" the word "life" or "soul"

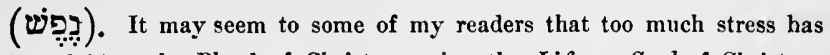
been laid on the Blood of Christ meaning the Life or Soul of Christ, $i$. e., the vital principle of His Hunanity (pp. 205, 246, 260). And they may ask, Do not the phrases "faith in His blood," "cleansed by His blood," simply mean by His Blood-shedding, i. e., by His Death? I would reply (1) that the phrase, "Faith in His Death" never occurs in Scripture; and (2) that the Blood of Christ is uniformly spoken of as a most living thing, now communicable to us. 
passion, He weakened the power of evil over us. In both ways, therefore, $\mathrm{He}$ made provision by $\mathrm{His}$ Death for our redemption from sin.

V. Lastly, and this last point links together the teaching of the whole Bible, as the angels linked together "the Song of Moses" and "the Song of the Lamb:" Our blessed Lord in working out this redemption of mankind fulfilled all that had been prefigured in the sacrificial ritual. But here the theological student must be careful. He must remember that sacrificial language is only applied by way of analogy to the death of Christ. ${ }^{1}$ Christ's death was in itself a Roman military execution. His blood was shed, not by a priest's sacrificial knife, but by the blade of a soldier's pilum. But it is no less true that the transcendent mystery of Divine mercy designed from the foundation of the world, and consummated in that historic Death, was the grand original of which all those Patriarchal and Levitical sacrifices were the faint copies. This, as Bishop Butler admirably points out, is the teaching of the Epistle to the $\mathrm{He}$ -

1 Coleridge's Aids to Reflection, and two scarce volumes of Sermons by Bishop Peter Browne, published in 1749 (to which, in the Reflexions on the Atonement, Coleridge seems to have been much indebted), show very clearly that an analogy is involved in all the sacrificial phrases that Scripture applies to the work of Christ, illustrating the consequences of the act, rather than the nature of the act itself. Analogy, being ioótrs rov hóyov, involves four terms: e. g., as the blood of the sin-offering cancelled ceremonial defilement, so the death of Christ cancelled sin: therefore by analogy Christ is called a " sin-offering." 
brews; it does not seek to explain Christ's Death by the aid of those sacrifices, but it seeks to explain those sacrifices by the aid of Christ's Death, showing its readers that, as the substance had now been revealed, the shadows might well cease.

But, with this caution premised, we may adopt the analogical language of Scripture, and speak of Christ's transcendent act as in the lighest sense of the term a sacrifice. And it was this in three ways:-

(1.) It expiated, or made atonement for, man's sin; meaning by this phrase that it rendered it possible for God to forgive sin without relaxation of the law of holiness. Herein it was prefigured by the sinofferings of the Levitic ritual.

(2.) It was the crowning act of a life-long obedience, an offering in absolute self-surrender of body, soul, and spirit unto God; the only perfect realization of that which the whole burnt-offering of the Patriarchal and of the Mosaic dispensation had faintly shadowed forth.

(3.) It was the inauguration of a New Covenant between God and man; whereas there had been an alienation of man from God, it made peace and reconciliation. It was symbolized, therefore, by the peace-offering, of which the offerer, as reconciled to God, always partook ; and most of all by the Paschal Lamb. "Christ our Passover is sacrificed for us, therefore let us keep the feast." 
Thus, in all three ways, Christ's death effected what those sacrifices foreshadowed without effecting.

We will now endeavor to summarize yet more briefly the teachings of Scripture as set forth in the last ten pages. It may perhaps be most conveniently done in the form of question and answer.

Why was a scheme of redemption needed? To deliver man from the consequences of the Fall.

What were the consequences of the Fall? Alienation from God, and bondage to evil.

Why could not God forgive by a word? It would have been a mere relaxation of the law of holiness to restore to favor one who was still essentially sinful.

But why could not God simply destroy man's sinfulness? Because in so destroying it, man's freedom of will would have been compromised.

How then could it be done? Only by way of a covenant between God and man, involving satisfaction on man's part, and an act of absolution on God's part.

Does satisfaction mean the payment of a debt, or the suffering of a penalty due from man to God? No; such ideas were the after-thoughts of scholastic divines, and are not found in Scripture. The pardon was of free grace; and the motive, love, not the requirement of compensation, or of punishment.

What, then, does the word satisfaction mean, when 
THE SOTERIOLOGY OF THE BIBLE. 275

used to express that which rendered man's pardon possible? It means the fulfilment of the law of holiness.

Was man able to give this satisfaction? No; therefore the Second Person of the Trinity became one of us, and on our part gave it.

In what way did Christ satisfy the law of holiness?

In His life, by exhibiting to man a perfect standard of holiness.

In His death, in three ways chiefly -

(1.) By dying unto sin on behalf of the whole race, whose head and representative He was :

(2.) By resisting, even unto death, the Evil One ; thereby destroying the ascendency which man's Fall had given him over the race :

(3.) By pouring forth His soul in death, that so it might become communicable (as a new principle of life) to all who would receive it.

In what sense was Christ's death vicarious? It was vicarious, inasmuch as $\mathrm{He}$ who in His own person had no need to die unto sin, died unto sin as Head of a race that needed so to die.

Thus all who are in Christ have in Him their death unto sin and their new birth unto holiness. And the Gospel is, to all who believe, not merely a doctrine, but "a power of God unto salvation." 


\section{TABULAR VIEW}

OF THE SCRIPTURES EXPLAINED OR QUOTED IN PART II., IN ILLUSTRATION OF THE DOCTRINE OF REDEMPTION.

Genesis

“

“

66

or

“

Exodus

“

"

"

Leviticus

"

ii. 17

iii. 15

iv. 7

xxii. 1-18

xlviii. 16

xlix. 18

xiii. 13,15

xxi. 30

xxx. 12-16

$\mathrm{xxx} .12,16$

X. 17

xvi. 22

xvii. 11

Xxv. 25-30

PAGE

173,208

175

- 173

176,177

176

176

200

200

201,202

178

- 179

179

178,205

199

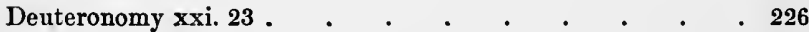

2 Samuel vii. 12,13 . . . . . . . . 183

Job

Psalms

6

"

6

66

《6

6

Isaiah

66

66

(6

Matthew

co

c

66

66

cc

6 xxxiii. $24 \quad$ • $\quad$ • $\quad$. $\quad$. $\quad$. 201

ii. 7 . . . . . . . . . 184

xvi. 10 . . . . . . . . 187

xl. 6,7,8 $. \quad . \quad . \quad . \quad . \quad . \quad . \quad . \quad 185$

xlv. $2,3,6 \quad . \quad . \quad . \quad . \quad \cdot \quad . \quad . \quad .185$

xlix. 7, 15 . . . . . . . 200

Ixxxix. 26-29, 38-49 . . . . . 184, 186

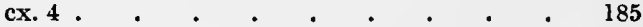

$\mathrm{xl} 11$. $\quad . \quad . \quad . \quad . \quad . \quad . \quad .187$

lii. 15 . $\quad . \quad$. $\quad . \quad$. 188,189

liii. 11 . . . . . . . . . 254

lix. $2 \quad \cdot \quad \cdot \quad \cdot \quad \cdot \quad . \quad . \quad . \quad .238$

viii. 17 . . . . . . 193, 255, 266

xii. 17-21 • . . . . . . . 193

xvii. $24 \quad . \quad . \quad . \quad . \quad . \quad . \quad .201$

xx. $28 \quad \cdot \quad . \quad . \quad . \quad . \quad . \quad . \quad . \quad 197$

xxvi. $26 \quad+\quad . \quad . \quad . \quad . \quad . \quad . \quad .204$

xxvi. $28 \quad$ • $\quad$ - . . . . 214, 264

xxrii. $46 \quad . \quad . \quad . \quad . \quad . \quad . \quad . \quad .211$ 


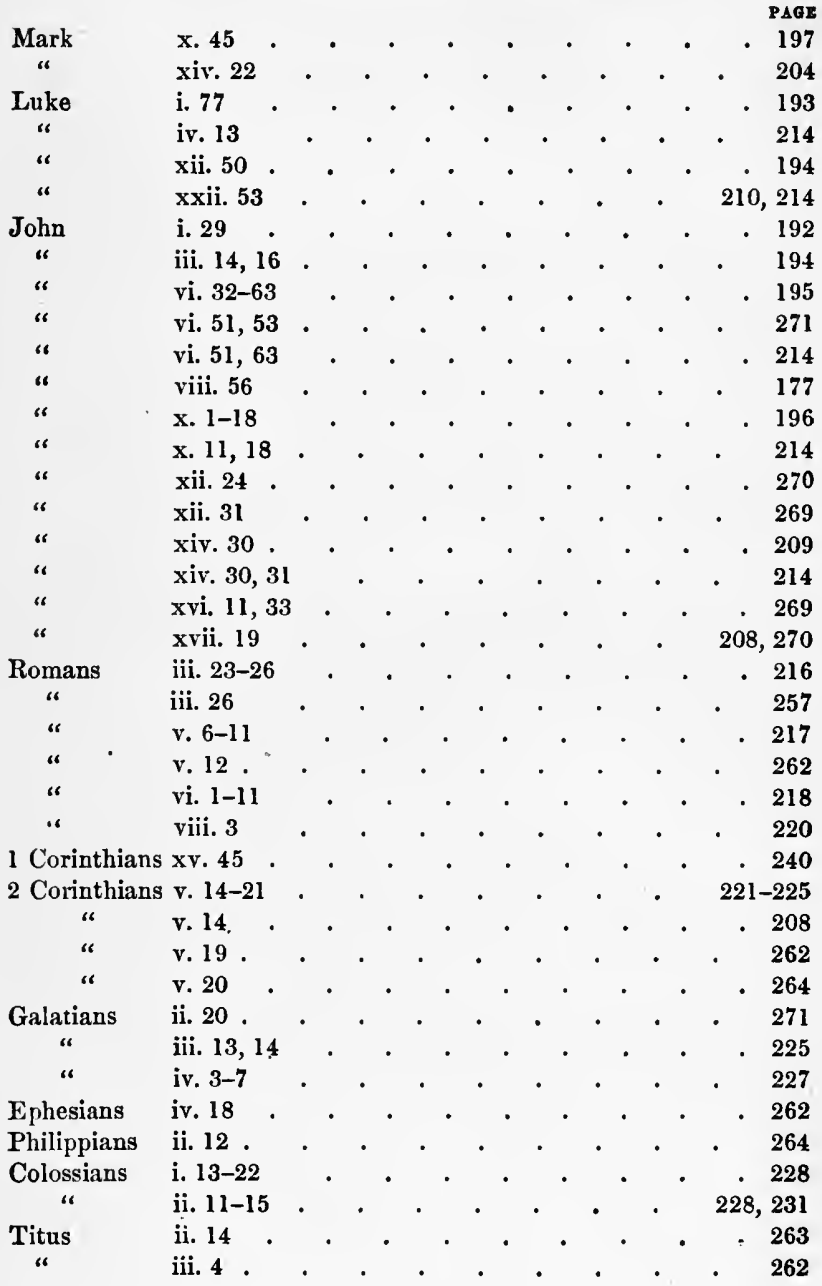




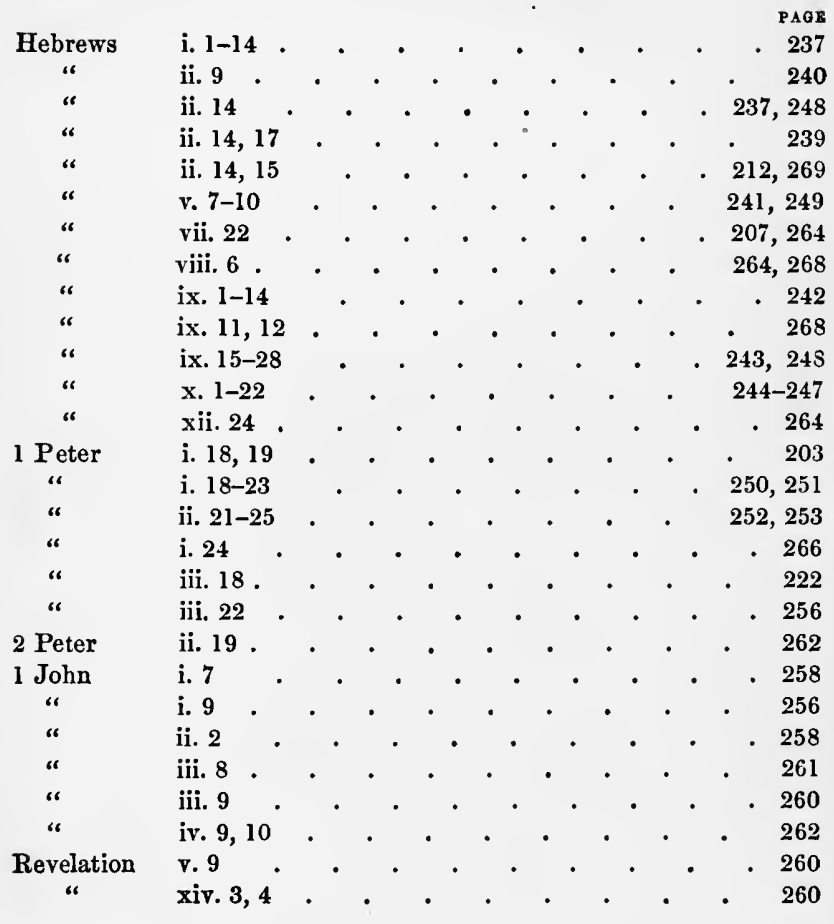




\section{GLOSSARIAL INDEX.}

Absolution, see Keys.

PAGES

AdaM, the whole race summed up in Christ as the Second Adam . . . . . . . . . . . . . . . . .

Apollinarian Herest, that our Lord had no human mind or anima rationalis, the Logos supplying its place . . . Arian Heresy, that Christ was a Divine Being, but created, refuted by Athanasius . . . . . . . . . . . .

Athanasian Creed, its doctrine of the Trinity . . . Atonement, Christ's Deatl expiated man's siu, thereby reconciling him to God, and redecming him from the Evil One . . . . . . . . . . . . . . . . . Summary of tẹaching of Scripture . . . . . . . See also under Satisfaction, for modern views.

BAPTISM : the Sacrament wherein we are admitted into the Christian Covenant. The outward sign is water with words ordained by Christ; the inward and spiritual gift is regeneration (see Regeneration). To the Covenant there are two sides: on our side certain responsibilities; on God's side, remission of the displeasure under which, as children of a fallen race, we are born, and admission to the sanctifying influences of the Holy Spirit. (See Original Sin) . . . . . . . . 147-152

Calvinistic Theory of the Atonement, that Christ suffered punishment as our substitute, open to grave objections

Christ, the doctrine of His Person . . . . . . . .

The doctrine of His death . . . . . . . . . . . 53

His character and His teaching alike imply a consciousness of Divinity . . . . . . . . . . . . . Church, a divinely-instituted Society, maintaining its con- 
tinuity by unity of doctrine, and by the due administration of the Sacraments . . . . . . . . . . .

Notes of the Church: One and the same Lord, one and the same Creed; the same two Sacraments ; Discipline, and a continuous Ministry. . . . . . . . . . .

The Discipline and Ritual need not be uniform, nor need the Ministerial Orders, so long as the commission is continuously transmitted; Episcopacy proved by experience to be the best safeguard for this continuity

Communion of Saints especially realized in the Eucharist

CoNsci exce, argument for God's existence from our instinctive sense of responsibility . . . . . . . . . . .

Couscrus, the doctrine of the Trinity and Incarnation as set forth in the first four General Councils - Nicaa, A. D. 325 , to refute Arians; Constantinople, A. D. 381 , to refute Macedonians and Apollinarians; Ephesus, A. D. 531, to refute Nestorians; Chalcedon, A. D. 451, to refute Eutychians . . . . . . . . . . .

Deatr - separation of soul and body ; used also in Scripturc for the scparation of the spiritual and carnal elements within us. When a man ceases to be spiritual, and becomes altogether carnal, he dies unto God (eternal deatlı); when he ceases to be carnal, and becomes al together spiritual, he dies unto Sin (expiatory) . . .

Christ's death a dying unto sin, that we might live unto God (Rom. vi. 10) . . . . . . . . . .

Eutrchias Heresy, that our Lord's human nature was so deified as to be human no longer . . . . . . . .

Expratiox, a death unto sin which shall satisfy the law of holiness. The Sin-offerings were not a true Expiation, but only a confession of the need of it. (See Death, Propitiation) . . . . . . . . . . 68, 260, 268

Filroque : the addition of this word to the Constantinopolitan Creed by the Spanish and Gallican Churches, sanctioned by a Provincial Council at Toledo A. D. 589, in accordance with St. Augustine's doctrine (De Trin. .iv. 20, and xv. 26), but without the authority of any 
PAGRS

Ecumenical Council, - was the ostensible cause which led to the breach between the Eastern aud Western Churches, and their excommunication of each other in A. D. 1053 ; the real cause being their struggle for supremacy. (See Procession) . . . . . . . .

Gon, arguments to prove His existence :-

1. A priori argument, from first principies of reason .

2. A posteriori argument from observation of design in nature . . . . . . . . . . . . . .

3. Moral argument from conscience . . . . . . . .

4. Spiritual evidence, from experience of communion, the strongest of all . . . . . . . . . . . . .

Grace : the word is used in two senses, sometimes for the $f a-$ vor ( $\left.\chi \alpha^{\alpha} \rho ı s\right)$ which bestows, sometimes for the gift ( $\left.\chi \alpha \dot{\rho} \rho \sigma \mu \alpha\right)$ bestowed. It is used in the latter sense in the definition of a Sacrament. For the particular gift bestowed in each Sacrament, see under BAPTISI and LonD's SupPER . . . . . . . . . . . . . .

Hocy Grost. The doctrine of His Personality and Individuality . . . . . . . . . . . . . .

(See Procession, Filioque.)

Impotation of our sin to Christ and of His righteousness to us, a doctrine required by the Calvinistic theory of Atonement, but unknowu to the Fatlers, and (as Bishop Bull has shown) devoid of scriptural authority . 62, 224, 266

INCARNATION : the doctrine of our Lord's two distinct natures . . . . . . . . . . . . . . . .

Infaxt Baptism, a Covenant, inasmuch as those same obligations which an adult Catecliumen takes on himself, are in the case of an infant put on him by others. .

Inspiration : certain men in the Apostolic age, and previously from time to time, were specially gifted to become organs of the Holy Spirit, - thcir natural faculties being quickened and illumined, but not superseded . . .

Reasons for believing that the books of both Old and New Testaments were written by men so gifted . . . 100-106 


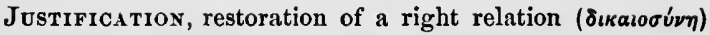
between God and man; effected once for all potentially by Christ, and appropriated individually by Faith or by a promise of Faith in Baptism . . . . . . .

KEYs : the power of the Keys called in Scripture " a binding and loosing," called also "a remitting and retaining of sin," meaning authority to admit into communion and to exclude therefrom. Considering that "in Comnunion with the Church" means "in Covenant with God," this responsibility would be more than any ministry could undertake without a Divine commission . . . . .

LORD'S SUPPER : a Sacrament in which the outward sign is bread and wine, taken (from the priest) and received bodily; and the inward gift, the Body and Blood of Christ, taken (from Christ) and received "after an heavenly and spiritual manner." The faithful partake of the latter as really as they do of the former; the outward thing being to them a Divine pledge that Christ is there and then giving them the inward . . . . . 152,153

The inward feeding (promised in John vi.) is such a participation in the sacrifice of Christ as makes us partakers of His quickening Spirit . . . . . . . . $155-159$

The outward sign, or form of conveyance was instituted twelve months after the inward gift had been promised. The effect of the words of consecration is to make the bread and wine a formal conveyance of that heavenly food which Christ bequeathed to us . . 153, 159

Ministry, see under Church. The Ministry of the Word, of the Sacraments, of Discipline, a means of Grace to those within the pale of the Church . . . . . .

Ministerial succession . . . . . . . . . 120, 125

Natural Theologx, evidence from Design . . . . . 19

Nestoriax Heresy, the son of Mary a human person into whom a Divine person entered

Orders, threefold orders of the Church's Ministry, dating 
from the earliest times, called (1) Apostles, (2) Bishops or Presbyters, (3) Deacons, in the first age ; (1) Bishops, (2) Priests, (3) Deacons, in the post-Apostolic times ; how far essential . . . . . . . . . . .

Original Sin, twofold, a wrong relation to God and a corrupt tendency of our nature, both inherited. The first is set right in Baptism, but the second remains, though counteracted by the influcnces of the Holy Spirit to which Baptism admits us. (See Baptism) . . .

Penal Theory of Christ's Death unscriptural. Not sanctioned by Isa. liii. . . . . . . . . . 61, 187-191, 254, 265

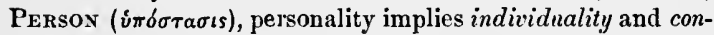
sciousness. A Person, an individual self-conscious being. The three Persons of the Divine substance differenced severally by Selfexistence, Generation, Procession. (See Substance) . . . . . . . . . . . . .

Procession: the Holy Ghost emanates from the Father through the Son, and therefore proceeds from both. (See Filioque) . . . . . . . . . . . . . .

Propitiation (i $\lambda \alpha \sigma \mu \delta s$ ), Heuthen sense of the word, obtaining mercy from an angry God by offer of compensation; Scriptural sense, obtaining mercy from the all-holy God by satisfaction of the law of holiness . . . . .

RAssom, the translation of the word $\lambda \dot{\tau} \tau \rho o \nu$ in Matt. xx. 28,

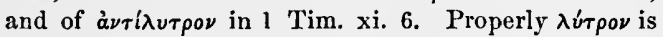
something that alsolves ( $\lambda v^{\prime} \epsilon t$ ), an expiation which obtains absolution of sin. But as sin is slavery, absolntion from sin is absolution (or release $\alpha \pi o \lambda \dot{v} \tau \rho \omega \sigma \iota s$ ) from slavery. Thus the $\lambda \dot{\tau} \tau \rho o \nu$ corresponds to a "ransom" in effect, though not in process, for no compensation to any one is implied . . . . . . . . . 81-83, 198-204

Real Presence, both the Giver and the Gift are really, though invisibly, present in the Eucharist. But it is to the Giver alone - the living glorified Person of our Lord, present "wherever two or three are gathered in His name" - that adoration is due . . . . . . 168-170

Reconciliation (of Man to God and of God to Man, essentially reciprocal) the effect of Christ's expiatory

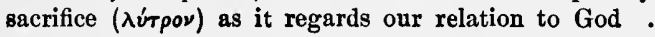


Redemption, the effect of Christ's expiatory sacrifice $(\lambda \dot{\tau} \tau \rho \nu)$ as it regards our relation to the Evil One, delivering us from our bondage to him. Hence, from parity of effect, the $\lambda u^{\prime} \tau \rho o \nu$ in this connection is translated by the word "ransom," but improperly. (See Ransom.) 'A dered absolution; and so St. Paul defines it. Eph. i. 7 ; Col. j. 14. . . . . . . . . . . . . . . .

Eneration God's gift in Baptism. That gracious act of God whereby for Christ's sake $\mathrm{He}$ adopts us as His children, translates us into the kingdom of His dear Son, and so brings us under the influence of the Holy Spirit . . . . . . . . . . . . . . .

Righteoussess, as used in the Epistle to the Romans, a right relation to God, a free gift of God . . . . .

Sabeldian Heresy : Sabellius denied that there were three distinct persons in the Godhead, saying that Father, Son, and Holy Spirit were but one Person appearing in three characters

SaCrament, defined in the Catechism to be "an outward and 43,44 visible sign of an inward and spiritual grace given unto us, ordained by Christ himself as a means wherchy we receive the same, and a pledge to assure us thercof" .

The sign or seal is (in legal phraseology) a form of conveyance. The grace is the unscen gift so con-

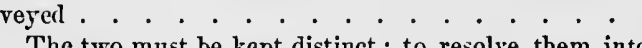

The two must be kept distinct; to resolve them into one would be to "overthrow the nature of a sacrament". . . . . . . . . . . . . .

SACRIFICE, three ways in which the Lord's Supper is a sacrifice, not propitiatory, but eucharistic; an offering (1) of the fruits of the earth, (2) of prayer and praise, (3) of ourselves .

Doctrine of Sacrifice . . . . . . . . . . .

Sacrifice, threefold, Sin Offering, Burnt Offering, Peace Offering . . . . . . . . . . . . . .

Our Lord's Death a sacrifice in all these three senses. . . . . . . . . . . . . . . . . .

Sanctification, growth in holiness through the influence of the Holy Spirit cousequent on Justification . . 
Satrsfaction, the meaning of the term as applied to Christ's Death, not a compensation for an unpaid debt, as Anselm taught; nor yet payment of a penalty, as Calvin and Grotius maintained; but a fulfilment of the law of holiness which required a death unto sin, as Athanasius more scripturally explained it . . . . . 208, 265

Scotrsts, their belief that even if there had been no Fall there would still have been an Incarnation, scriptural .

SigN, defined" by St. Augustine to be "a thing which, besides the impression it makes on the senses, of itself suggests the thought of something else to the mind" .

Soteriologr, the Doctrine of Salvation . . . . .

SpIrit, see Holy Ghost.

Substance, the Latin equivalent of the Greek word oúria or Essence. Self-existent in the Father, communicated by the Father to the Son, and by the Father through the Son to the Holy Ghost. "De Patre est Filius, de Patre est Spiritus Sanctus, sed Ille genitus est, Iste procedens." - Aug. C. Maxim. ii. 14 . . . . 45, 90, 95, 96

Transubstantiation, how the error arose in the time of Paschasius (ninth century), and was first sanctioned A. D. 1215 Five proofs that it is "repugnant to the plain words of Scripture" (xxviii. Art.). . . . . . . . . . 163, 164

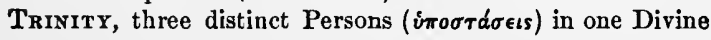
Essence or Substance (oúría) . . . . . . . . . . 46, 90

Vrcarious, true meaning of the term as applied to the Death of Christ given in 2 Cor. v. 14. Christ so died on behalf of all that all died potentially in Him . . . 222

Christ died as Surety for the Race (Heb. iii. 22) 207, 240, 241

WILL : In the Trinity there is but one will; in Christ incarnate there are two wills in perfect harmony, for $\mathrm{He}$ "learned obedience" (Heb. v. 8) . . . . . . . . 










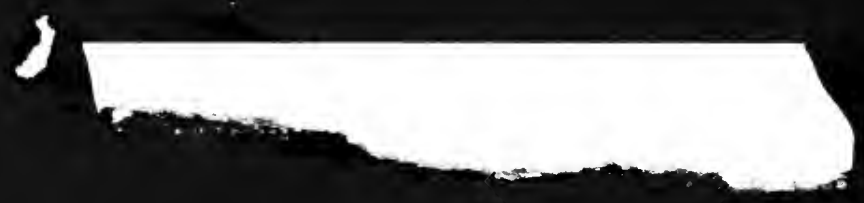


$\downarrow$ 


\section{,}

r.

wats 